\title{
ALGUMAS PROPRIEDADES MECÂNICAS DO MÚSCULO \\ GASTROCNÊMIO DE RATAS SUBMETIDAS A UM MODELO DE \\ HIPOATIVIDADE E TRATADAS COM EXERCITAÇÃO
}

\section{MARCOS ANTÔNIO PARREIRA LARA}

Dissertação apresentada ao programa de pósGraduação Interunidades em Bioengenharia Escola de Engenharia de São Carlos / Faculdade de Medicina de Ribeirão Preto / Instituto de Química de São Carlos, da Universidade de São Paulo, para obtenção do título de Mestre em Bioengenharia.

ORIENTADOR: Prof. Dr. José B. Volpon

Ribeirão Preto

2003 


\section{SUMÁRIO ${ }^{1}$}

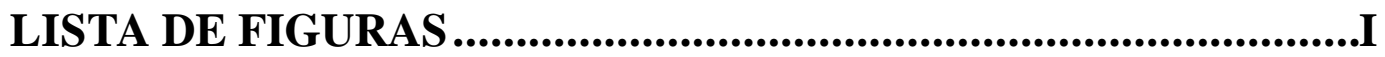

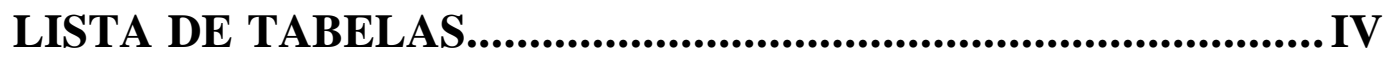

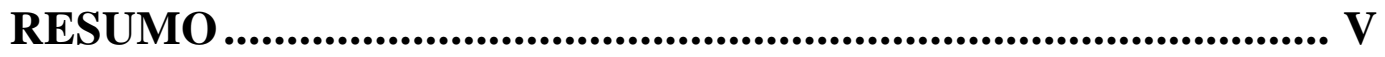

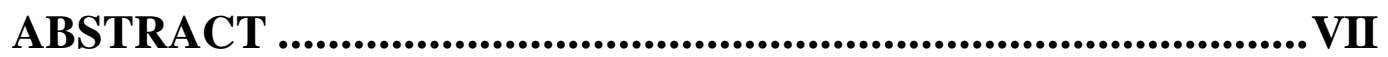

1 INTRODUÇÃ

1.1 O tecido muscular .....................................................................................1

1.2 Atrofia muscular........................................................................................4

1.2.1 Atrofia induzida por microgravidade ......................................6

1.3 Ensaio Mecânico ..................................................................................................... 12

1.3.1 Ensaio de tração............................................................... 13

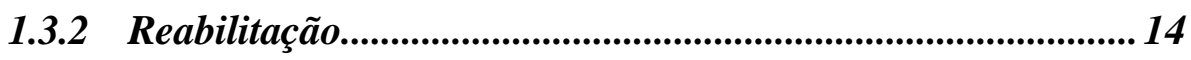

1.4 Justificativa do estudo .......................................................................... 14

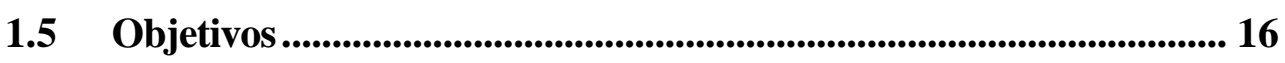

2 MATERIAL E MÉTODO....................................................... 17

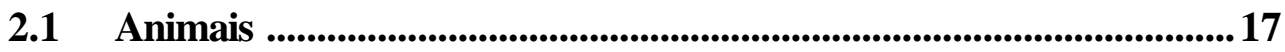

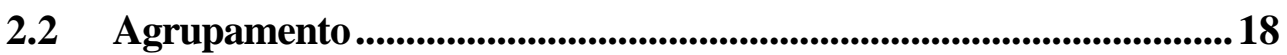

2.3 Características dos grupos .............................................................. 19

2.3.1 Grupo controle ...................................................................... 19

2.3.2 Grupo 7 dias de suspensão....................................................... 19

2.3.3 Grupo 14 dias de suspensão.................................................... 20

2.3.4 Grupo 21 dias de suspensão................................................... 20

2.3.5 Grupo 7 dias de suspensão seguidos de 30 dias de natação....20

2.3.6 Grupo 14 dias de suspensão seguidos de 30 dias de natação.. 20

2.3.7 Grupo 21 dias de suspensão seguidos de 30 dias de natação.. 21

2.4 Técnica de suspensão...............................................................................21

\footnotetext{
${ }^{1}$ Normas de acordo com as diretrizes para elaboração de dissertações e teses na EESC-USP, $2^{\mathrm{a}}$ ed.
} 
2.5 Técnica de exercitação ....................................................................24

2.6 Coleta de material .....................................................................................26

2.7 Ensaio mecânico de tração ................................................................26

2.7.1 Propriedades mecânicas .......................................................228

2.7.1.1 Limite de proporcionalidade $(L P)$...............................29

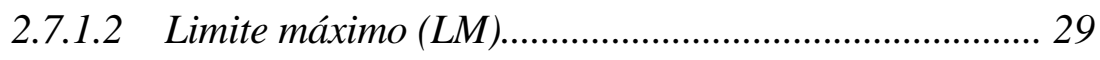

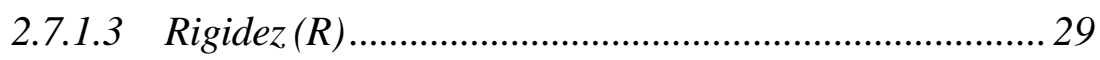

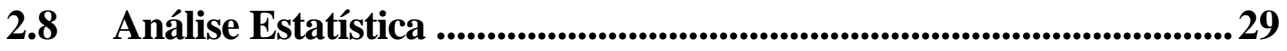

3 RESULTADOS .............................................................. 31

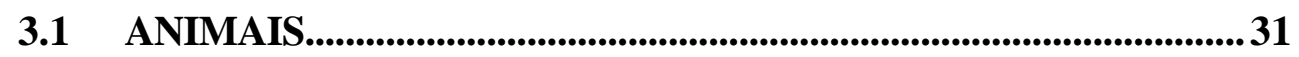

3.2 PROPRIEDADES MECÂNICAS ........................................................3 34

3.2.1 Ensaios mecânicos:................................................................34

3.2.2 Limite de proporcionalidade .....................................................45

3.2.2.1 Carga no limite de proporcionalidade........................... 45

3.2.2.2 Deformação no limite de proporcionalidade ................. 48

3.2.3 Limite máximo........................................................................51

3.2.3.1 Carga no limite máximo .................................................51

3.2.3.2 Deformação no limite máximo ..................................... 54

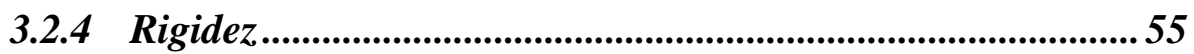

4 DISCUSSÃ 0 ................................................................. 58

5 CONCLUSÕES ............................................................. 70

6 REFERÊNCIAS BIBLIOGRÁFICAS .................................. 71

$7 \quad$ ANEXOS 


\section{LISTA DE FIGURAS}

FIGURA 1 - Gaiola para suspensão de rato pela cauda, constituída de duas partes. A inferior, em acrílico serve de base para acoplamento da superior, em metal raiado. ...... 21

FIGURA 2 - Rato em suspensão pela cauda, mostrando os componentes da gaiola............22

FIGURA 3 - Materiais usados para fixação da cauda do rato em suspensão. Tintura de Benjoin (A). Espuma adesiva (B). Codornê (C). Presilha (D). Fita de brim (E). Faixa elástica adesiva $(\mathrm{F})$.

FIGURA 4 - Passos técnicos para a fixação da cauda do animal. Colocação da espuma adesiva envolvendo a cauda do rato (A). Enfaixamento com faixa elástica adesiva sobre uma fita de brim, formando uma alça no final (B). Colocação da presilha para acoplamento no eixo de suspensão após amputação da extremidade distal da cauda (C).

FIGURA 5 - Esquema ilustrativo do tanque com o aquecedor e o cano de drenagem da

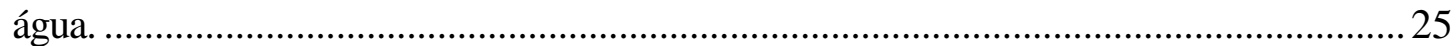

FIGURA 6 - Desenho esquemático mostrando detalhes anatômicos do músculo gastrocnêmio do rato (in http://www.nsbri.org/humanphysiologyspacelfocus5/

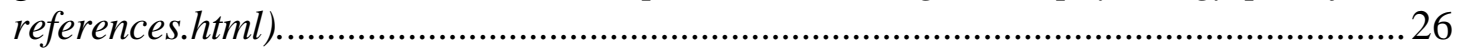

FIGURA 7 - Detalhe do músculo gastrocnêmio sendo submetido ao ensaio de tração em uma fase inicial (I) e final (II), ilustrando o acessório para fixação do fêmur (A) e do acessório para fixação do calcâneo (B). Notar o posicionamento do músculo perpendicularmente às inserções e o alongamento sofrido pelo músculo após o ensaio. 27

FIGURA 8 - Gráfico carga $x$ deformação ilustrando os pontos de obtenção das propriedades mecânicas com o ensaio de tração. Dmáx = deformação máxima; $\mathrm{LM}=$ limite máximo; Dprop.= deformação proporcional; LP = limite de proporcionalidade; Cprop = carga proporcional; Cmáx = carga máxima; $\theta=$ ângulo de inclinação da reta .28

FIGURA 9 - Valores dos pesos dos animais controle e ao início ( I ) e final ( F ) de 7, 14 e 21 dias de suspensão.

FIGURA 10 - Valores dos pesos dos animais controle e ao início ( I ) e final ( S ) de 7, 14 e 21 dias de suspensão, seguidos de 30 dias de natação (N).

FIGURA 11 - Curvas Carga $x$ Deformação individuais dos músculos gastrocnêmios dos 12 animais-controle.

FIGURA 12 - Médias \pm EP das curvas Carga $x$ Deformação dos músculos gastrocnêmios dos 12 animais controle.

FIGURA 13 - Curvas Carga $x$ Deformação individuais dos músculos gastrocnêmios dos 11 animais suspensos por 7 dias

FIGURA 14 - Médias \pm EP das curvas Carga x Deformação dos músculos gastrocnêmios

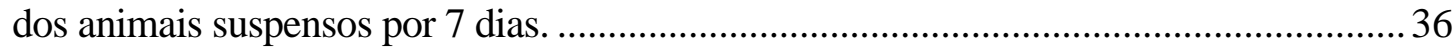

FIGURA 15 - Curvas Carga $x$ Deformação individuais dos músculos gastrocnêmios dos 14 animais suspensos por 14 dias

FIGURA 16 - Médias \pm EP das curvas Carga $x$ Deformação dos músculos gastrocnêmios dos animais suspensos por 14 dias. 
FIGURA 17 - Curvas Carga $x$ Deformação individuais dos músculos gastrocnêmios dos 12 animais suspensos por 21 dias. 38

FIGURA 18 - Médias \pm EP das curvas Carga $x$ Deformação dos músculos gastrocnêmios dos animais suspensos por 21 dias. .38

FIGURA 19 - Curvas Carga $x$ Deformação ndividuais dos músculos gastrocnêmios dos 13 animais suspensos por 7 dias, e seguidos de 30 dias de natação. .39

FIGURA 20 Médias \pm EP das curvas Carga $x$ Deformação dos músculos gastrocnêmios dos animais suspensos por 7 dias, e seguidos de 30 dias de natação.

FIGURA 21 - Curvas Carga $x$ Deformação individuais dos músculos gastrocnêmios dos 15 animais suspensos por 14 dias, e seguidos de 30 dias de natação. 40

FIGURA 22 - Médias \pm EP das curvas Carga $x$ Deformação dos músculos gastrocnêmios dos 15 animais suspensos por 14 dias, e seguidos de 30 dias de natação.

FIGURA 23 Curvas Carga $x$ Deformação individuais dos músculos gastrocnêmios dos 14 animais suspensos por 21 dias, e seguidos de 30 dias de natação.

FIGURA 24 - Médias \pm EP das curvas Carga $x$ Deformação do músculo gastrocnêmio dos animais suspensos por 21 dias, seguidos de 30 dias de natação.

FIGURA 25 - Comportamento (média \pm EP) dos músculos gastrocnêmio dos animais controle (C) e dos suspensos pelos períodos de 7 (7d), 14 (14d) e 21 dias (21d)............ 42

FIGURA 26 - Comportamento (média \pm EP) dos músculos gastrocnêmio dos animais controle (C) e dos suspensos pelos períodos de 7 (7d), 14 (14d) e 21 dias (21d) seguidos de 30 dias de natação.

42

FIGURA 27 - Comparação dos ensaios mecânicos (média+ EP) dos músculos gastrocnêmios de animais controles (C), suspensos por 7 dias (7d) e suspensos por 7 dias seguidos de natação $(7 \mathrm{~d}+\mathrm{N})$.

FIGURA 28 - Comparação dos ensaios mecânicos (média+ EP) dos músculos gastrocnêmios de animais controles (C), suspensos por 14 dias (S14) e suspensos por 14 dias seguidos de natação $(\mathrm{S} 14+\mathrm{N})$

FIGURA 29 - Comparação dos ensaios mecânicos (média+ EP) dos músculos gastrocnêmios de animais controles (C), suspensos por 21 dias (21d) e suspensos por 21 dias seguidos de natação $(21 \mathrm{~d}+\mathrm{N})$

FIGURA 30 - Carga no limite da proporcionalidade do músculo gastrocnêmio de ratas controle e submetidas a 7, 14 e 21 dias de suspensão. .46

FIGURA 31 - Carga no limite da proporcionalidade do músculo gastrocnêmio de ratas controle e ratas submetidas à suspensão por 7 dias seguidos ou não de natação.

FIGURA 32 - Carga no limite da proporcionalidade do músculo gastrocnêmio de ratas controle e ratas submetidas à suspensão por 14 dias seguidos ou não de natação............ 47

FIGURA 33 - Carga no limite da proporcionalidade do músculo gastrocnêmio de ratas controle e ratas submetidas à suspensão por 21 dias seguidos ou não de natação............ 48

FIGURA 34 - Deformação no limite da proporcionalidade do músculo gastrocnêmio de ratas submetidas a diferentes períodos de suspensão. (Não há diferença estatística quando cada grupo é comparado com o controle).

FIGURA 35 - Deformação no limite da proporcionalidade do músculo gastrocnêmio de ratas controle e ratas submetidas à suspensão por 7 dias seguidos ou não de natação. ...49

FIGURA 36 - Deformação no limite da proporcionalidade do músculo gastrocnêmio de ratas controle e ratas submetidas à suspensão por 14 dias seguidos ou não de natação. .49 
FIGURA 37 - Deformação no limite da proporcionalidade do músculo gastrocnêmio de ratas controle e ratas submetidas à suspensão por 21 dias seguidos ou não de natação. .50

FIGURA 38 Carga no limite máximo de músculo gastrocnêmio de ratas submetidas a diferentes períodos de suspensão, em relação ao controle. 52

FIGURA 39 - Carga no limite máximo do músculo gastrocnêmio de ratas submetidas à suspensão por 7 dias seguidos ou não de natação.

FIGURA 40 - Carga no limite máximo do músculo gastrocnêmio de ratas submetidas a suspensão por 14 dias seguidos ou não de natação.

FIGURA 41 - Carga no limite máximo do músculo gastrocnêmio de ratas submetidas a suspensão por 21 dias seguidaos ou não de natação. .53

FIGURA 42 - Deformação no limite máximo do músculo gastrocnêmio de ratas submetidas a diferentes períodos de suspensão. .54

FIGURA 43 - Rigidez do músculo gastrocnêmio de ratas submetidas à suspensão por 7 dias

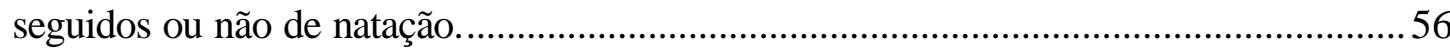

FIGURA 44 - Rigidez do músculo gastrocnêmio de ratas submetidas à suspensão por 14

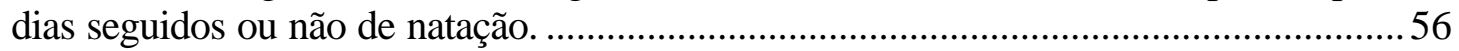

FIGURA 45 - Rigidez do músculo gastrocnêmio de ratas submetidas à suspensão por 21 dias seguidos ou não de natação. 


\section{LISTA DE TABELAS}

Tabela 1 - Número de animais e peso (média \pm desvio padrão) antes e após os respectivos

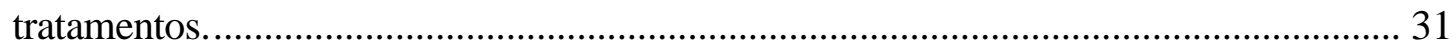

Tabela 2 - Valores médios \pm desvio padrão de carga e deformação no limite de

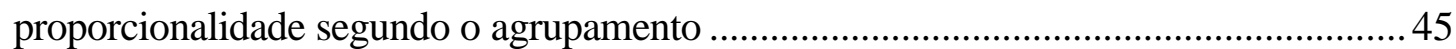

Tabela 3 - Valores médios \pm desvio padrão de carga e deformação no limite máximo

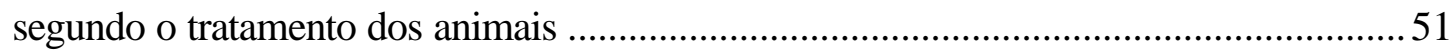

Tabela 4 - Valores médios \pm desvio padrão de rigidez segundo o tratamento dos animais .55 


\section{RESUMO}

Existe grande necessidade de informações sobre a consequência da diminuição de carga nos músculos esqueléticos, de modo a se definirem programas adequados de prevenção da atrofia decorrente da inatividade, assim como de programas visando à recuperação das lesões já estabelecidas.

No presente estudo avaliamos o impacto de períodos de 7, 14 e 21 dias de retirada de carga do membro posterior por meio da suspensão, nas características mecânicas do músculo gastrocnêmico em ratas e a possibilidade de recuperação desse músculo após 30 dias de natação.

Por meio de ensaio de tração traçou-se a curva de carga $x$ deformação do músculo gastrocnêmio, de onde foram obtidos os valores da carga e deformação no limite da proporcionalidade, carga e deformação máximas e rigidez.

A carga no limite da proporcionalidade foi menor nos animais suspensos por 7 e 21 dias e a carga no limite máximo foi menor aos 7 dias quando comparado com o controle. A deformação, em ambas situações, e a rigidez foram semelhantes ao controle.

A carga no limite de proporcionalidade aumentou após a natação para todos os períodos de suspensão, atingindo significância estatística para os grupos de 7 e 21 dias. A deformação no limite da proporcionalidade assim como a carga no limite máximo de deformação, foram significativamente diferentes nos animais submetidos a natação quando comparados com os suspensos pelo mesmo período. A deformação no limite máximo não 
apresentou diferença entre os grupos, mas a rigidez foi maior para todos os grupos de animais submetidos à natação.

Como conclusão verificamos que o sistema de suspensão pela cauda foi bem tolerado pelos animais e promoveu enfraquecimento significativo do músculo estudado. $\mathrm{O}$ exercício a que as ratas foram submetidas foi capaz de reverter as alterações causadas pela hipoatividade. 


\begin{abstract}
Information is needed on the effect of lack of weight on skeletal muscle, and adequate programs should be defined for the prevention of atrophy due to absence of weight, as well as programs aiming at the recovery of lesions already established.

In the present study we evaluated the impact of periods of 7, 14 and 21 days of load removal from the hind limb by means of suspension on the mechanical characteristics of the gastrocnemius muscle of female rats and the possibility of muscle recovery after 30 days of swimming.

A traction assay was used to construct the load $x$ deformation curve from which load and deformation values at the elastic limit, as well as the ultimate load and deformation and stiffness values were obtained.

Load at the yield limit was lower for animals submitted to limb suspension during 7 and 21 days and load at the ultimate limit was lower at 7 days compared to control. Deformation and rigidity were similar to control in both situations.

Load at the yield limit increased after swimming after all periods of suspension, and reached statis tical significance for the 7 and 21 day groups. Deformation at the yield limit and load at the ultimate limit were significantly different in the animals submitted to swimming compared to those submitted to suspension for the same periods of time. Deformation at the ultimate limit did not differ between groups, but stiffiness was greater for all groups of animals submitted to swimming.
\end{abstract}


We concluded that the tail suspension model was well tolerated and promoted significante weakness of the muscle.

The exercise was able to reverts the alterations caused by hipoactivity. 


\section{INTRODUÇÃO}

O movimento é uma característica fundamental do ser humano, sendo o músculo esquelético, dentre os tecidos, o mais plástico, portanto, mutável e respondendo a estímulos normais e patológicos. Cerca de $50 \%$ do peso do corpo humano é composto de músculos e, em um período de 7 a 14 dias, metade das proteínas das células dos músculos são renovadas (ROSE e ROTHSTEIN, 1982).

A função muscular depende da inervação motora, da mobilidade articular e da carga mecânica que lhe é imposta. Se um desses fatores é modificado para mais ou para menos, o músculo, por sua enorme plasticidade, termina por se adaptar.

\subsection{O tecido muscular}

O músculo é uma estrutura motora cuja função é baseada na propriedade de encurtar-se e alongar-se produzindo, assim, uma força que pode produzir movimento articular ou estabilização articular. É o elemento motor do corpo humano, acionando voluntária ou involuntariamente os segmentos corpóreos.

O músculo está contido numa bainha de tecido fibroso, conhecida por fáscia ou epimísio. Dela partem septos conjuntivos (perimísio) que, penetrando na substância do músculo, o dividem em pequenos feixes de fibras. Cada feixe consiste em um conjunto de outras fibras que são as unidades funcionais do músculo. A fibra também divide- se em fibrilas. 
Cada fibra tem sua própria bainha elástica, que é conhecida por sarcolema, que permite seu alongamento e encurtamento. Dentro do sarcolema encontram-se numerosos núcleos que pertencem à fibra muscular e existem proteínas contrácteis dentro das fibras musculares arranjadas em unidades paralelas, miofibrilas, que são ativadas por um nervo motor. O sarcolema é perfurado por uma fibra nervosa, formando a placa terminal que é dependente do sistema nervoso central, que emite descargas elétricas que provocam as contrações musculares. Entre as fibras há muitos vasos sangüíneos, assegurando uma boa irrigação (ROSE e ROTHESTEIN, 1982).

Uma característica importante das miofibras multinucleadas é que seus núcleos não se dividem. O crescimento do músculo pós-natal ocorre quase que exclusivamente por meio da hipertrofia das miofibras sem sua hiperplasia. No entanto, concomitantemente com a hipertrofia da miofibra ocorre o aumento de seu conteúdo de DNA. Uma população de células satélites mitoticamente ativa situada entre a miofibra e o sarcolema (MAURO, 1961) doa novos mionúcleos para as miofibras aumentadas (MOSS e LEBLOND, 1971). As células satélites não são só importantes por alimentar as miofibras em crescimento com mais núcleos, mas também são muito importantes após a lesão muscular. Imediatamente após a lesão os fragmentos de miofibra são removidos, as células satélites são ativadas e recuperam a sequiência de eventos embrionários para formar miotúbulos que amadurecerão em novas miofibras (ANDERSON, 1998). Dados recentes sugerem que outros tipos de células, como as derivadas da medula óssea, podem contribuir para a regeneração muscular (FERRARI et al., 1998). Mas, ainda é desconhecido se a contribuição desses outros tipos celulares é significante quantitativamente. No entanto, durante o crescimento das miofibras substituídas, as células satélites continuam doando núcleos. Dessa forma, as células satélites têm uma capacidade proliferativa que não é completamente avaliada durante o 
crescimento normal. Cada mionúcleo individual dentro da miofibra, gerado pela divisão da célula satélite, deve ter papel importante no crescimento muscular, porque eles coordenam a transcrição das proteínas da fibra muscular para o citoplasma.

A unidade de DNA é a quantidade teórica de citoplasma que é suportada em cada um dos núcleos da miofibra multinucleada (CHEEK, 1985; RALSTON e HALL, 1992; ALLEN; ROY; EDGERTON, 1999). A expressão coordenada de proteínas específicas do músculo dentro da miofibra deve ser um processo muito complexo, porque milhares de núcleos podem ser encontrados dentro de um segmento de fibra muscular, e nem todos os núcleos estão em transcrição ativa ao mesmo tempo (NEWLANDS et al., 1998). Da mesma forma, a relação entre a agregação de mionúcleo por meio da adição de um novo núcleo e a unidade de tamanho do DNA também deve ser complexa devido aos diversos fatores que regulam a proliferação das células satélite, fusão das células satélite e tamanho da miofibra. Apesar de uma pletora de fatores de crescimento influenciarem a diferenciação e proliferação das células satélites, é possível que as fibras musculares sejam muito importantes no controle da proliferação das células satélites e na fusão da miofibra. (BISCHOFF, 1990; MOZDZIAK et al., 1998; YABLONKA-REUVENI; SEGER; RIVERA, 1999). Assim, a inter-relação entre miofibra e a população de células satélite é importante para determinar o tamanho final do músculo, já que a agregação mionuclear é o principal determinante do tamanho muscular (MOZDZIAK; SCHULTS; CASSENS, 1997).

Durante o crescimento normal dos músculos esqueléticos existe um desenvolvimento programado do aumento do tamanho da unidade de DNA (MOZDZIAK; SCHULTS; CASSENS, 1997; MOZDZIAK; PULVERMACHER; SCHULTS, 2000) . No entanto, durante uma resposta adaptativa em músculo maduro, os núcleos das células satélite são adicionados num ritmo suficiente para manter constante o tamanho da unidade 
de DNA (McALL et al., 1998). A manutenção de um tamanho constante da unidade de DNA durante a adaptação da miofibra em um músculo maduro sugere que a hipertrofia da miofibra seja dependente da agregação mionuclear. A manutenção de um tamanho da unidade de DNA constante durante a hipertrofia da miofibra, decorrente de carga mecânica, sugere uma relação direta entre o número de núcleos e a quantidade de proteínas na miofibra (McALL et al., 1998; MOZDZIAK et al., 2001).

Existem três principais tipos de fibras musculares esqueléticas, cada uma com propriedades bioquímicas e fisiológicas únicas, que podem ser diferenciadas por técnicas histoquímicas:

a - tipo I: contração lenta e oxidativa.

b - tipo Ila: contração rápida e glicolítica oxidativa.

c - tipo Ilb: contração rápida e glicolítica.

Músculos de contração rápida ou lenta são desenhados para diferentes funções. Os músculos lentos são responsáveis pelo suporte postural e suporte do peso, enquanto que os músculos rápidos são talhados para a força e movimentação rápida. As fibras de contração lenta são resistentes à fadiga, e as de contração rápida têm tendência a se fadigarem mais rapidamente (CLOSE, 1967; BROOKE e KAISER, 1970).

\subsection{Atrofia muscular}

A atrofia é manifesta pela perda exponencial de massa do músculo esquelético em relação ao tempo, em função da diminuição do número de miofibrilas em paralelo, assim como o número de fibras por músculo (FAULKNER et al, 1980; KASPER et al., 1993). 
A diminuição da massa muscular, diâmetro das células musculares, e número de fibras por músculo foram descritos em músculo esquelético de ratos após perda de peso e restrição de movimentação por meio de engessamento e outros métodos. (BOOTH e KELSO, 1973; HERBISON; JAWEED; DITUNNO, 1978; MUSACCHIA et al 1980; MOREY-HOLTON e WRONSKI, 1981; JASPER e TISCHLER, 1984; KASPER; WHITE; MAXWELL, 1990).

Quando um músculo não é usado por longos períodos de tempo, a quantidade de miofilamentos de actina e miosina diminui, levando à redução no diâmetro individual de cada fibra e à diminuição da força muscular. Estas alterações, por sua vez, levam a modificações importantes nas características de contração dos músculos (BALDWIN, 2001).

Se estas características de contração são drasticamente alteradas a composição de suas fibras também alterará. Assim, pessoas que são confinadas à cama por doença, ou astronautas que, enquanto no espaço, não utilizam os "músculos anti-gravitacionais", desenvolvem atrofia muscular. Este processo ocorre quando uma pessoa fica em repouso restrito ao leito por mais de duas semanas, ou quando o membro é imobilizado (GUTMANN e HNIK, 1963). A atrofia por desuso pode ser atrasada pela contração intermitente do músculo contra a resistência (HISLOP, 1964).

A propagação de potenciais de ação para as fibras musculares de uma unidade motora é acompanhada pela liberação de substância tróficas que impedem a atrofia (GUTH, 1980). Uma doença ou trauma nos motoneurônios inferiores que inervam um músculo remove a fonte do fornecimento contínuo de substâncias tróficas. As fibras afetadas sofrem uma atrofia de desnervação progressiva, até que sejam reinervadas por brotos dos axônios 
motores próximos que sobreviveram, ou pelo crescimento axonal da extremidade proximal do nervo seccionado.

Se a inervação não for realizada dentro de aproximadamente dois anos, todas as miofibrilas contráteis terão sido substituídas por um tecido conjuntivo fibroso, e o músculo não será mais capaz de desenvolver tensão ativa.

Estudos mostraram que as fibras musculares e outros tecidos não neurais produzem substâncias que o neurônio necessita para a sua operação contínua. Tais substâncias são chamadas neuronotrofinas, e parecem penetrar pela extremidade distal do axônio, onde são capturadas e transportadas por toda sua extensão até o corpo celular, processo chamado de fluxo axoplasmático (GRAFSTEIN e FORMAN, 1980). Para que, tanto as fibras musculares, quanto as nervosas permaneçam saudáveis é necessário o fornecimento contínuo de substâncias tróficas. O uso do sistema neuromuscular serve como um estímulo para a síntese das substâncias tróficas, e a falta de uso conduz à deterioração funcional e estrutural.

\subsubsection{Atrofia induzida por microgravidade}

Apesar dos cientistas virem desenvolvendo experimentos com a biologia gravitacional há muito tempo, foi só nos últimos 40 anos que se tornou possível o estudo dos sistemas neuromotores, quando submetidos a curtos períodos de pouca gravidade (EDGERTON e ROY, 2000).

O primeiro ser vivo lançado ao espaço foi a cadela soviética Laika, em novembro de 1957, e o primeiro humano foi Yuri Gagarin, em 12 abril de 1961. O desenvolvimento dos projetos de vôos espaciais tripulados permitiu ao homem chegar à lua e permanecer por longos períodos em órbita terrestre (ex. MIR, SKYLAB ). Essa incrível tecnologia levou o 
ser humano a ambientes sem gravidade, para o qual não havia sido biologicamente preparado. Foi, então, que começaram a surgir estudos observando alterações orgânicas decorrentes da exposição do organismo humano a esses ambientes (WEST, 2000).

Os estudos desenvolvidos durante a era das estações espaciais russas evidenciaram a capacidade humana de realizar trabalho em ambientes de microgravidade por longos períodos (KOSLOVSKAIA et al., 1981; KOSLOVSKAIA et al., 1990). A presença quase contínua de humanos em ambientes de microgravidade utilizando-se de biosatélites ou estação espacial Mir, desde 1970, ofereceram os fundamentos científicos e o conhecimento básico sobre a tolerância do corpo humano a ambientes de baixa gravidade. Até o momento várias centenas de humanos viajaram para o ambiente espacial. Apesar desse constante acesso e testes de tolerância de humanos ao ambiente espacial, as naves espaciais limitaram os estudos a poucas espécies. A despeito de uma grande gama de animais e plantas terem sido expostos ao ambiente de baixa gravidade, quase todas essas exposições foram por períodos inferiores a três semanas. Além disso, em todas naves espaciais, ficam muito limitadas as oportunidades de se desenvolver estudos bem controlados. Basicamente, a experiência conseguida no espaço serviu para estimular os estudos da biologia gravitacional e determinou a importância do entendimento dos fundamentos da biologia na Terra (EDGERTON e ROY, 2000).

A gravidade desenvolve um papel fundamental na definição das propriedades biológicas dos organismos, em grande parte baseadas nas propriedades físicas do ambiente.

Isso pode ser claramente demonstrado quando pássaros tentaram voar na estação espacial Mir, mas não conseguiram controlar seu senso de direção de vôo. Entre as espécies animais da Terra, existem diversos exemplos de assimetria dos sistemas musculares com respeito à direção e níveis de força que devem ser acomodadas para manter a mobilidade e 
repertórios adequados de movimentos de escape e reprodutivos (EDGERTON e ROY, 2000).

Também é importante entender como os sistemas de suporte energético são concebidos para manter o desempenho no ambiente de gravidade comparados com o ambiente de menor gravidade (CHANG e KRAM, 1999; CHANG et al., 2000). A intricada regulação e integração do controle neural dos músculos que desenvolvem um trabalho também tem de ser efetivos, de forma que sejam distribuídas quantidades adequadas de substrato e oxigênio para as fibras musculares mais ativas, que necessitam de maior metabolismo oxidativo. A distribuição sangüínea deve ser controlada respeitando a gravidade durante as tarefas motoras e posturais. As fibras musculares que são solicitadas mais freqüentemente e que trabalham contra a gravidade devem possuir grande capacidade de fosforilação oxidativa e, assim, gerar fosfatos de alta energia.

Apesar do conceito básico de que todos organismos terráqueos desenvolvem-se em ambiente de gravidade ser evidente, esse conceito é muito pouco realçado. Em recente revisão Booth et al. (2000) apontam para o fato interessante de que nossa sociedade, atualmente, apresenta doenças em escala epidêmica associadas à falta de atividade. A biologia humana e seu genoma evoluíram em ambiente em que a atividade física sempre foi um componente básico. Esse ambiente foi e continua sendo importante na seleção dos genes que caracterizam os humanos. Em geral, se reconhece ser necessário que se mantenha certo grau de atividade física para a manutenção da homeostase normal do organismo. Associada a essa atividade física está o trabalho muscular, muito do qual se realiza contra as forças gravitacionais.

Por exemplo, grande proporção dos músculos de ação lenta tem grande capacidade de oxidação, como pode ser notado basicamente nos músculos extensores em quase todos 
os mamíferos, inclusive o homem. Essas fibras musculares parecem ter sido desenvolvidas especialmente para manter a postura ereta durante o dia causando o mínimo estresse metabólico. Em contraste, os músculos com atividade primariamente flexora têm relativamente maior proporção de fibras rápidas e mais fatigáveis, refletindo a não função antigravitacional desses músculos. É de se supor que se um organismo se desenvolvesse em ambiente de microgravidade não seria necessária essa assimetria nos tipos musculares (EDGERTON e ROY, 2000).

Os organismos submetidos à ausência ou diminuição da gravidade sofrem múltiplos efeitos sendo que a atrofia e diminuição de força muscular são os grandes problemas musculares enfrentados pelos tripulantes em vôos espaciais.

Em vista que o desenvolvimento de estudos tendo como base os vôos espaciais evidentemente são difíceis, foram desenvolvidos sistemas artificiais visando a mimetizar os efeitos da ausência de gravidade. Hoje se pode dizer que, basicamente, existem duas maneiras de simular a ausência de peso em animais. Na versão de suspensão pela cauda, os membros raseiros são desprovidos do suporte do peso, pela tração da cauda ou da coluna, mantendo-se apenas as patas dianteiras em contato com o assoalho da gaiola, para permitir locomoção (MOREY, 1979). Em outra versão, menos usada, o animal é suspenso por meio de uma armadura no corpo (MUSACCHIA et al., 1980).

O sistema de suspensão dos membros posteriores é um excelente modelo de atrofia muscular e de transição das isoformas das cadeias pesadas da miosina semelhante ao que ocorre durante os vôos espaciais (TALMADGE; ROY; EDGERTON, 1996). É ainda um modelo útil de inatividade muscular. É sabido que o sistema de suspensão induz à apoptose (EDGERTON et al., 1997), diminui o número de mionúcleos em ratos (ALLEN et al., 1996; ALLEN et al., 1997; HIKIDA et al, 1997), reduz o tamanho da unidade de DNA 
(KASPER e XUN, 1996) e induz a atrofia no músculo esquelético maduro. Ainda, sabe-se que o sistema de suspensão suprime a atividade mitótica das células satélites de músculos jovens e inibe o crescimento do músculo esquelético (DARR e SCHULTZ, 1989; SCHULTZ; DARR; MACIUS, 1994; MOZDZIAK; PULVERMACHER; SCHULTS, 2000). Por último, sabe-se que a retirada da carga de peso dos membros posteriores não inibe a formação de miofibras após lesão muscular, mas reduz o crescimento das fibras recém formadas em substituição às lesionadas (MOZDZIAK et al., 1998).

Ilyna - Kakueva; Portugalov; Krivenkova (1976) relataram que, em músculos de ratos examinados histologicamente e morfologicamente após 22 dias de vôo, o músculo solear sofreu considerável perda de peso, e pelo $27^{\circ}$ dia após o vôo, comparando com um grupo controle, apresentou recuperação altamente efetiva. Os mesmos autores relataram, também, que a exposição dos ratos à ausência de peso por 20 dias resultou em significativa perda de massa no músculo solear e gastrocnêmio.

Chui e Castleman (1980) relataram que em ratos expostos a hipogravidade por 18 dias, houve redução no diâmetro médio das fibras do extensor longo dos dedos, juntamente com uma redução de toda área de fibra muscular e porcentagem de fibras de contração lenta. Eles postularam que a hipogravidade resulta em ambas: hipocinesia e hipodinamia.

Oganov et al. (1980) demonstraram que a ausência de peso resulta em propriedades contráteis alteradas e tensão isométrica reduzida. Musacchia; Steffan; Deavers (1981) relataram perdas de $35 \%$ de massa muscular nas fibras de contração lenta do músculo solear (tipo I) de ratos, na primeira semana de suspensão dos membros posteriores e $45 \%$ na segunda semana. No músculo plantar, onde predominam as fibras de contração rápida (tipo II), a suspensão induziu a apenas $22 \%$ de perda da massa muscular após sete dias de suspensão. 
Thomason e Booth (1990) demonstraram que a porcentagem de fibras de contração lenta diminui no músculo solear sob ausência de peso, e que a combinação de fibras atrofiadas e a diminuição na porcentagem de fibras de contração lenta, necessariamente, muda as propriedades contráteis do músculo solear sob ausência de peso. Assim, o músculo sóleo (contração lenta) adquire propriedades contráteis mais rápidas durante sua exposição à ausência de peso.

Uma secção transversal do gastrocnêmio foi corada com miosina ATPase para distinguir fibras do tipo I das do tipo II. Dos seis músculos gastrocnêmios de ratos suspensos por uma semana, um mostrou maior perda de fibras tipo II, quando comparadas com tipo I. Dos 10 músculos gastrocnêmios examinados de ratos suspensos por duas semanas, quatro apresentaram atrofia uniforme das fibras tipo I e tipo II. Dos 12 músculos examinados de ratos suspensos por quatro semanas, quatro demonstraram atrofia, três apresentaram maior perda de fibras tipo I e um apresentou atrofia uniforme de fibras tipo I e II (TEMPLETON et al., 1984-a).

A maior influência nos músculos com fibras lentas causados tanto pelos vôos espaciais como pelo sistema de Morey fica evidente, quando se comparam os dados dos vôos espaciais e dos ratos hipocinéticos. A marcante perda de peso do sóleo em comparação com a pequena ou nenhuma perda do músculo predominantemente rápido gastrocnêmio é um exemplo. A perda de peso do sóleo foi de $22 \%$ e $25 \%$ nos vôos de 21 dias da COSMOS-605 e 20 dias da COSMOS 690, respectivamente (TEMPLETON et al., 1984-b). Ratos suspensos por duas e quatro semanas pelo método de Morey tiveram perda de peso do sóleo que eram de $40 \%$ e $50 \%$ do controle, respectivamente (TEMPLETON et al., 1984-b). Em contraste, as perdas de peso do gastrocnêmio dos animais submetidos ao mesmo vôo foram insignificantes, da mesma forma que nos ratos suspensos por períodos 
curtos de 14 dias. As semelhanças de resposta tanto do sóleo como do gastrocnêmio decorrente de vôo espacial e do sistema de suspensão de Morey indicam que este último sistema é um modelo válido para avaliar as alterações surgidas na gravidade baixa. Uma vantagem oferecida pelo sistema de Morey sobre o vôo espacial é que o ele permite maior controle e flexibilidade dos experimentos.

\subsection{Ensaio Mecânico}

Inicialmente, os ensaios mecânicos eram usados quase que exclusivamente no campo da Engenharia. Com o aparecimento dos implantes não orgânicos e com a necessidade de se determinar as propriedades mecânicas dos materiais e tecidos orgânicos, surgiu uma nova área de pesquisa que beneficia a Medicina e a Reabilitação: a Bioengenharia.

O conhecimento das características de resistência de alguns materiais é importante na medicina ortopédica e esportiva. Materiais biológicos tais como músculos, ossos, ligamentos, tendões e cartilagens muitas vezes necessitam de otimização de sua resistência para evitar a ruptura (GOULD III, 1993; CARVALHO, 2001). A Engenharia colabora com a avaliação das propriedades mecânicas dos tecidos componentes do corpo humano ou dos materiais que são utilizados para substituir ou reparar alguma parte dele. Para estudar o comportamento dos materiais ou tecidos, quando submetidos a esforços, utilizam-se os chamados ensaios mecânicos.

Nesses estão incluídos os ensaios de tração, compressão, torção e outros. Estes tipos compreendem a maioria dos ensaios realizados em tecidos biológicos. O tipo de ensaio a 
ser empregado depende do tipo de material a ser utilizado, bem como sua finalidade, tipo de esforço e propriedades mecânicas. Existem dois tipos básicos de ensaios mecânicos feitos em materiais biológicos: os destrutivos, que chegam a causar ruptura total ou parcial do tecido e os não destrutivos. Nos ensaios não destrutivos as alterações não são permanentes e correspondem aos ensaios com utilização de ultra-som, raios-x etc. (SOUZA, 1977).

\subsubsection{Ensaio de tração}

O ensaio de tração é considerado o mais importante, pela facilidade de execução e reprodução dos resultados e há muito tem sido utilizado (MACMASTER 1933).

Ele consiste em submeter um material a um esforço que tende a esticá-lo promovendo deformação (SOUZA, 1977). O ensaio de tração permite medir a resistência do material. Para mais fidedignidade de um ensaio, é necessária uma precisão dos aparelhos de medida que estão dispostos para tal procedimento.

O corpo de prova é fixado em uma máquina que aplica esforços padronizados e crescentes na direção axial longitudinal, sendo medidas as deformações por meio de um extensômetro. O corpo de prova deve estar bem alinhado para que o esforço ocorra em direção do eixo longitudinal. Neste ensaio as deformações são distribuídas uniformemente para todo o corpo, pelo menos até ser atingida a carga máxima. O ensaio de tração permite medir satisfatoriamente a resistência do material já que é capaz de fazer com que a carga cresça lentamente durante o teste (SOUZA, 1977). Para que os resultados obtidos sejam confiáveis é preciso que o ensaio seja realizado seguindo as normas e padronizações (CHIAVERINI, 1977). 


\subsubsection{Reabilitação}

Várias métodos foram avaliados na sua habilidade de melhorar ou prevenir atrofia do músculo esquelético durante a microgravidade (NORMAN et al., 2000) . De-Doncker; Picquet; Falempin, (2000) mostraram que a estimulação dos receptores mecânicos da planta do pé do rato poderia prevenir, parcialmente, a atrofia do músculo sóleo desenvolvida depois de 14 dias de suspensão.

A contra-medida mais freqüentemente avaliada é o exercício (GUTH e SAMAHA, 1969; HERBERT; ROY; EDGERTON, 1988; THOMASON e BOOTH, 1990). Nenhum exercício até o momento preveniu completamente a atrofia muscular durante períodos de falta de peso (KAVOUNOUDIAS; ROLL; ROLL, 1998).

Grindeland et al. (1994) relataram que a administração diária de hormônio de crescimento humano acompanhado de subir escada preveniu a atrofia do sóleo em ratos após 10 dias de suspensão. O uso combinado de exercícios com hormônio, foi mais eficaz que qualquer um dos tratamentos isoladamente. De uma forma geral, sugere-se que os programas para evitar os efeitos da microgravidade vão ter que ser compostos não só de exercícios constantes, mas também de componentes de exercício de alta resistência. Quanto e qual exercício de alta resistência ainda deve ser estudado.

\subsection{Justificativa do estudo}

Como se constata na literatura, é muito grande o interesse e necessidade de informações sobre o impacto da falta ou diminuição da solicitação do peso nos músculos esqueléticos, o que significa menor demanda mecânica. Existe grande necessidade de se 
definirem programas adequados de prevenção da atrofia decorrente da ausência de solicitação do peso, assim como programas visando à recuperação das lesões já estabelecidas.

No presente estudo se avaliou o impacto do modelo de suspensão nas características mecânicas do músculo gastrocnêmio e a possibilidade de recuperação desse músculo por meio de um programa de treinamento ulterior ao período de ausência de peso. 


\subsection{Objetivos}

O presente estudo teve os seguintes objetivos;

1. Avaliar o comportamento mecânico, em ensaio de tração, do músculo gastrocnêmio de ratas, quando submetidos a modelo de hipoatividade durante diferentes períodos de tempo.

2. Avaliar o comportamento mecânico, em ensaio de tração, do músculo gastrocnêmio de ratas, quando submetidos a modelo de hipoatividade durante diferentes períodos de tempo, seguidos por um período de exercitação pela natação. 


\section{MATERIAL E MÉTODO}

Anteriormente aos experimentos, foram realizados ensaios piloto para definir e padronizar os ensaios mecânicos, a velocidade da tração exercida, a fixação do músculo estudado à maquina de ensaios, a carga e a pré- carga utilizadas, as medidas das gaiolas, o modelo de suspensão e a fixação da cauda do animal.

\subsection{Animais}

Foram utilizadas 105 ratas adultas jovens (Rattus norvegicus albinus) da linhagem Wistar, com peso corporal mínimo de $200 \mathrm{~g}$ e máximo de $295 \mathrm{~g}$, com média de 247,5g, no início do experimento. Os animais foram fornecidos pelo Biotério Central da Prefeitura do Campus de Rbeirão Preto, da Universidade de São Paulo e pelo Biotério da Universidade de Franca, São Paulo.

As ratas foram mantidas no biotério do Laboratório de Bioengenharia da Faculdade de Medicina de Ribeirão Preto e ocuparam gaiolas coletivas, com dois ou três animais por gaiola, até que fosse atingido o peso mínimo estabelecido, para o início da fase de suspensão. Após essa etapa, elas foram colocadas em gaiolas individuais especiais para serem suspensas pela cauda.

Foram utilizadas cinco gaiolas com as mesmas características, contendo um animal por gaiola com acesso livre à água e à alimentação. Os animais foram identificados por números em suas gaiolas, variando de 1 a 5 e pesados no início do experimento, no início da fase de natação e no dia do sacrifício. 


\subsection{Agrupamento}

Nesse trabalho foram investigadas as variações de algumas propriedades mecânicas do músculo esquelético, após o membro posterior ter sido submetido à retirada de carga por meio da suspensão dos animais pela cauda, seguido ou não de um período de exercitação na água.

Houve um grupo controle e seis grupos tratados, distribuídos conforme o tempo de suspensão isoladamente, ou a suspensão seguida de exercitação.

GRUPO CONTROLE -sem tratamento

GRUPO 7 dias de suspensão

GRUPO 14 dias de suspensão

GRUPO 21 dias de suspensão

GRUPO 7 dias de suspensão seguidos de 30 dias de natação

GRUPO 14 dias de suspensão seguidos de 30 dias de natação

GRUPO 21 dias de suspensão seguidos de 30 dias de natação 


\subsection{Características dos grupos}

A distribuição dos animais está apresentada no Quadro I.

Quadro I - Distribuição dos animais nos grupos experimentais

\begin{tabular}{cc}
\hline Grupos experimentais & Número de animais \\
\hline Controle & 12 \\
7 dias de suspensão & 11 \\
14 dias de suspensão & 14 \\
21 dias de suspensão & 12 \\
7 dias de suspensão com 30 dias de natação & 13 \\
14 dias de suspensão com 30 dias de natação & 15 \\
21 dias de suspensão com 30 dias de natação & 14 \\
\hline TOTAL & $\mathbf{9 1}$
\end{tabular}

\subsubsection{Grupo controle}

Composto por 12 animais que foram mantidos em gaiolas comuns, sem restrição de ração e água e sem intervenções específicas, sacrificados quando atingiram o peso entre $225 \mathrm{~g}$ e $285 \mathrm{~g}$, com média de $264 \mathrm{~g}$. .

\subsubsection{Grupo 7 dias de suspensão}

Composto por 11 animais com as características físicas semelhantes ao do grupo controle, e com peso no início da suspensão entre $215 \mathrm{~g}$ e $270 \mathrm{~g}$, com média de $246 \mathrm{~g}$. Essas ratas ficaram suspensas pela cauda por um período de 7 dias e, depois, sacrificadas. 


\subsubsection{Grupo 14 dias de suspensão}

Composto por 14 animais com características físicas semelhantes ao do grupo anterior, com peso inicial entre $235 \mathrm{~g}$ e $255 \mathrm{~g}$ e média de $248 \mathrm{~g}$. Foram suspensos pela cauda por um período de 14 dias e, depois, sacrificados.

\subsubsection{Grupo 21 dias de suspensão}

Composto por 12 animais com as mesmas características físicas dos grupos anteriores. Os animais apresentaram peso inicial médio de $262 \mathrm{~g}$, com variação entre $230 \mathrm{~g}$ e $295 \mathrm{~g}$, e foram suspensos pela cauda por um período de 21 dias, sendo sacrificados em seguida.

\subsubsection{Grupo 7 dias de suspensão seguidos de 30 dias de natação}

Composto por 13 animais com as mesmas características dos grupos anteriores. Foram suspensos pela cauda por um período de 7 dias. Os animais apresentaram peso inicial médio de $234 \mathrm{~g}$, com variação entre $200 \mathrm{~g}$ e $245 \mathrm{~g}$. Após o período de suspensão foram submetidos a exercícios de natação, com duração de uma hora diária durante 30 dias, e, depois sacrificados.

\subsubsection{Grupo 14 dias de suspensão seguidos de 30 dias de natação}

Composto por 15 animais com as mesmas características dos grupos anteriores que ficaram suspensos pela cauda por um período de 14 dias. Os animais apresentaram variação de peso no início da suspensão entre $225 \mathrm{~g}$ e $260 \mathrm{~g}$, com peso médio de $244 \mathrm{~g}$. Após a suspensão, os animais foram submetidos à natação por um período de 30 dias, uma hora ao dia, e, depois, sacrificados 


\subsubsection{Grupo 21 dias de suspensão seguidos de 30 dias de natação}

Composto por 14 animais com as características semelhantes aos grupos anteriores. Os animais apresentaram uma variação de peso no início da suspensão entre $230 \mathrm{~g}$ e $280 \mathrm{~g}$, com media de 256g. Após a suspensão foram submetidos à natação de uma hora por dia, durante 30 dias.

\subsection{Técnica de suspensão}

Os animais foram suspensos pela cauda utilizando-se um modelo simulador de microgravidade proposto por Kasper et al., (1993) e modificado por Silva (2003). Previamente, foram construídas gaiolas especiais (Figura 1) compostas por duas partes separadas que se acoplavam. A parte inferior foi feita em acrílico transparente e incolor,com medidas de $35 \mathrm{~cm}$ x $35 \mathrm{~cm}$ x $21,5 \mathrm{~cm}$ e com um orifício em um dos lados para colocar o bico de água. A parte superior foi fabricada em metal raiado com medidas de $36 \mathrm{~cm}$ x $36 \mathrm{~cm}$ x $21 \mathrm{~cm}$.

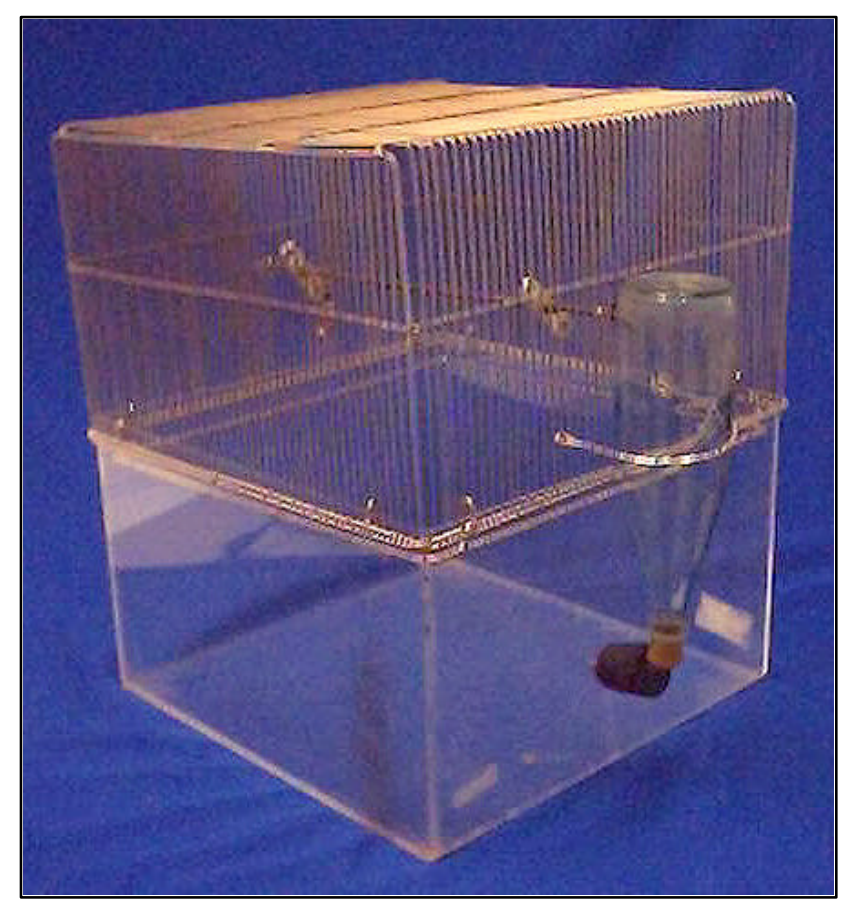

FIGURA 1 - Gaiola para suspensão de rato pela cauda, constituída de duas partes. A inferior, em acrílico serve de base para acoplamento da superior, em metal raiado. 
De um lado a outro da parte superior e central da gaiola metálica foi colocada uma barra cilíndrica e de ferro com superfície rosqueada, que serviu para posicionar e sustentar os animais nas gaiolas. Nesta barra foi inserida uma presilha que permitia o deslizamento ao longo do eixo, onde foram dependurados os animais (Figura 2).

A água foi colocada em uma garrafa presa na lateral, com um bico que atravessava a parede da gaiola, em uma altura que permitia ao animal utilizá-la quando houvesse necessidade. A ração foi simplesmente colocada dentro da gaiola, que teve seu piso forrado com serragem.

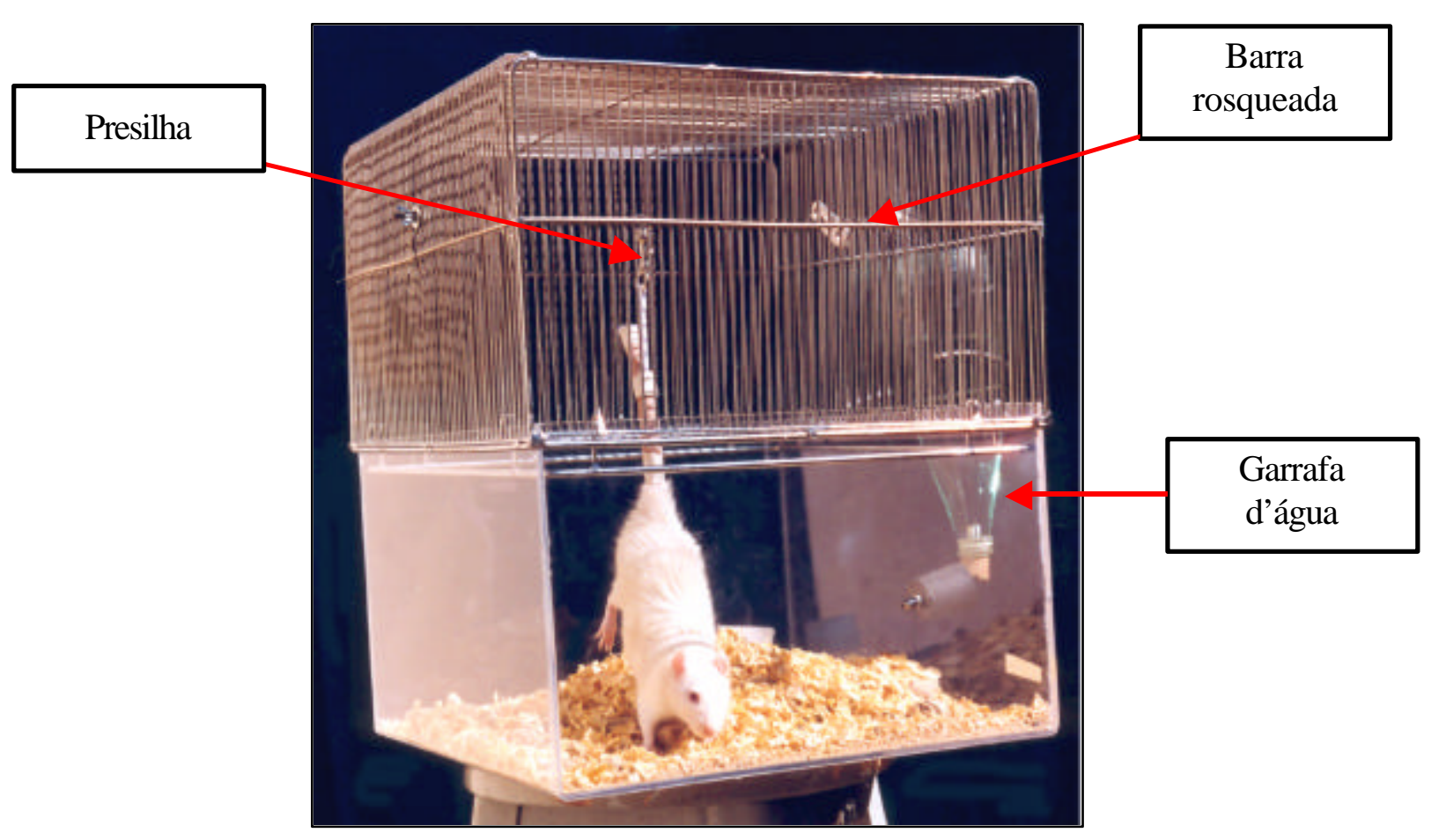

FIGURA 2 - Rato em suspensão pela cauda, mostrando os componentes da gaiola.

Para a instalação do sistema de suspensão as ratas foram anestesiadas com inalação de éter etílico, para a limpeza de suas caudas com detergente, aplicação de tintura de Benjoin para melhorar a aderência. Duas tiras de espuma adesiva $\left(\right.$ Reston $^{\circledR}$ ) foram aplicadas envolvendo os dois terços proximais da cauda, para proteção cutânea. Sobre a espuma foi 
enrolada uma fita de brim formando uma alça, que foi envolvida por uma bandagem elástica compressiva (Elastoplast ${ }^{\circledR}$ ) e presa com cordonê. (Figuras 3 e 4).

Esta alça de brim foi acoplada à presilha que deslizava pela barra rosqueada e que estava fixada às laterais da gaiola, presas por parafusos de rosca que permitiam o ajuste na altura da suspensão, de modo que o animal apoiasse os membros anteriores apenas o suficiente para a locomoção e não apoiasse ou tocasse os membros posteriores nas paredes da caixa acrílica.

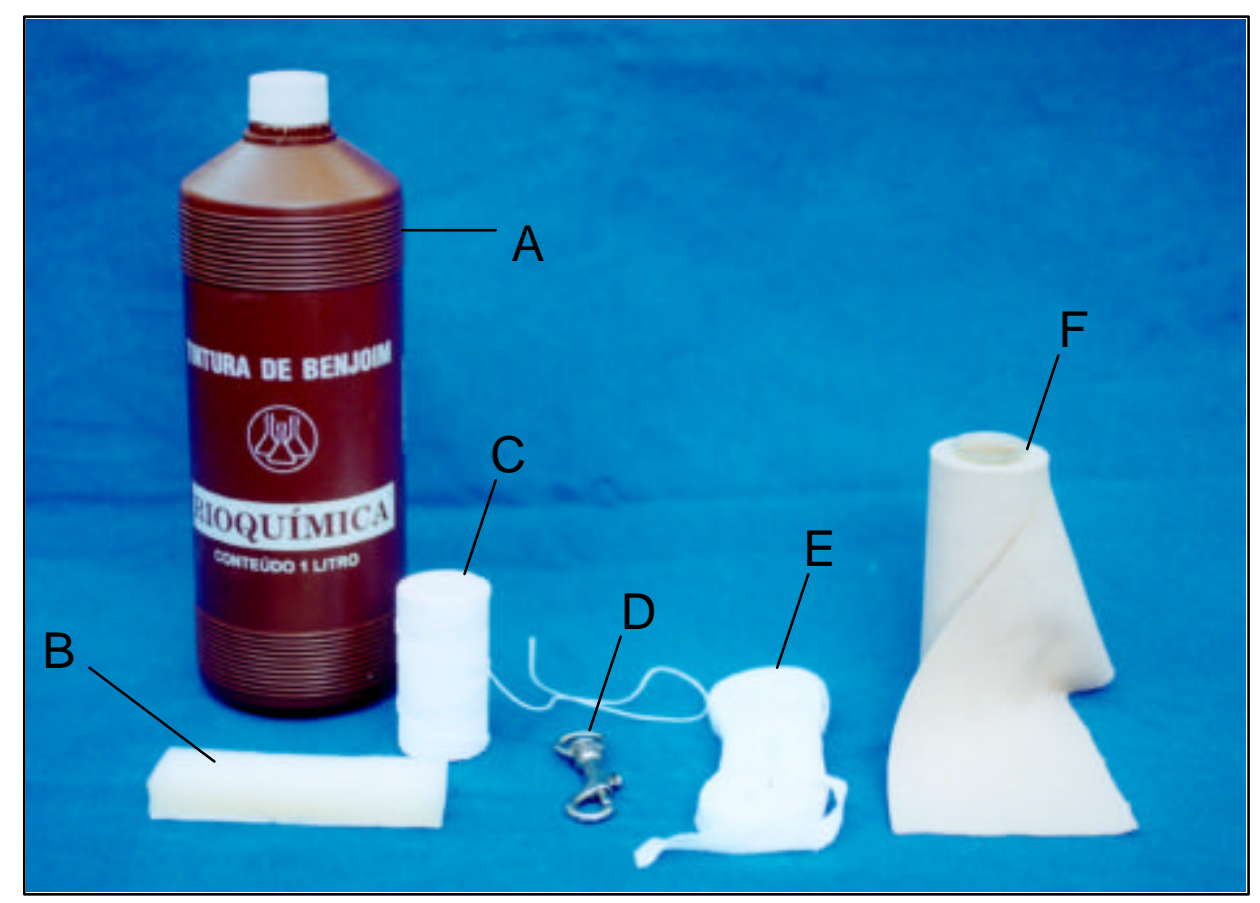

FIGURA 3 - Materiais usados para fixação da cauda do rato em suspensão. Tintura de Benjoin (A). Espuma adesiva (B). Codornê (C). Presilha (D). Fita de brim (E). Faixa elástica adesiva (F). 


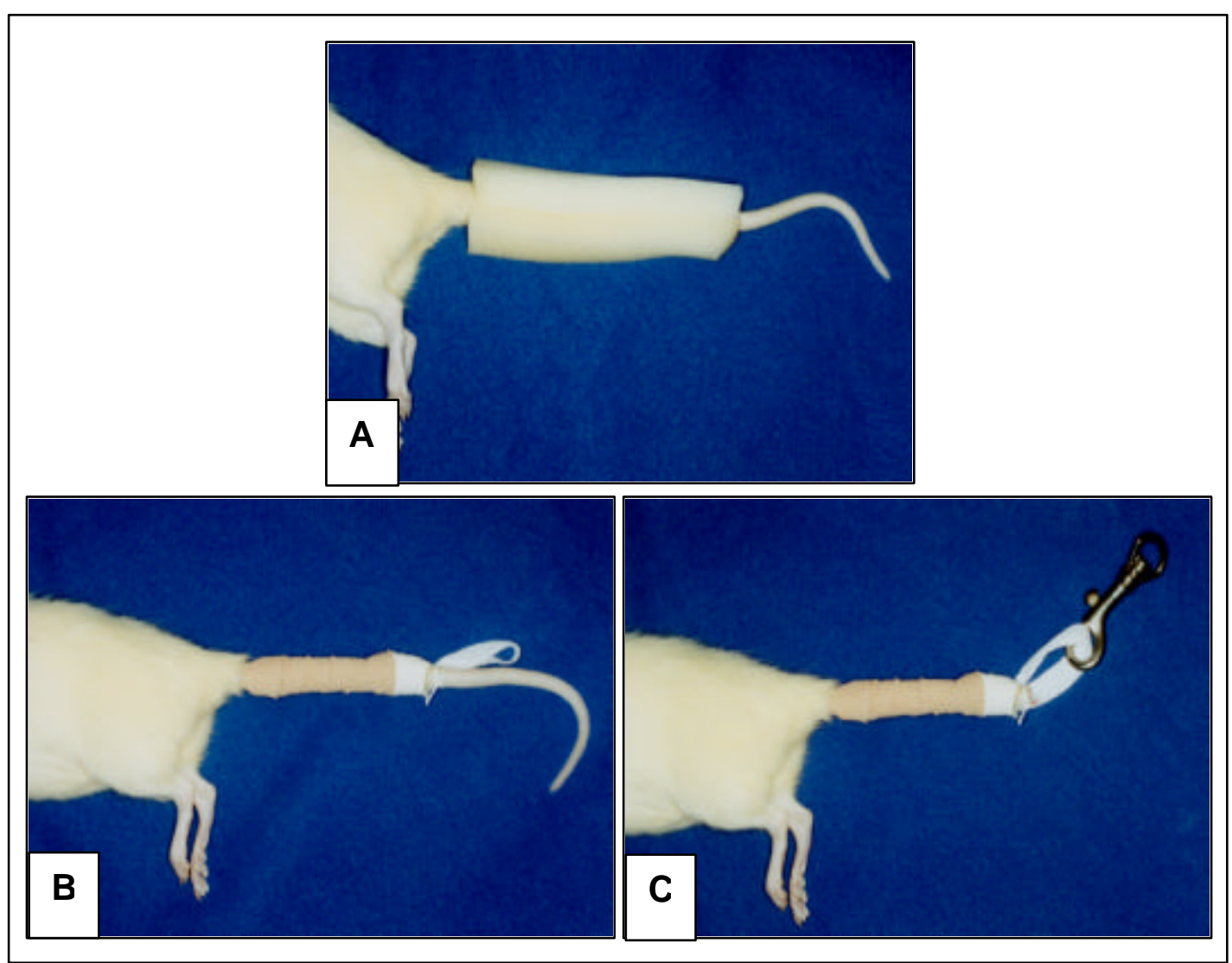

FIGURA 4 - Passos técnicos para a fixação da cauda do animal. Colocação da espuma adesiva envolvendo a cauda do rato (A). Enfaixamento com faixa elástica adesiva sobre uma fita de brim, formando uma alça no final (B). Colocação da presilha para acoplamento no eixo de suspensão após amputação da extremidade distal da cauda (C).

Após o término do enfaixamento o terço final da cauda que ficara livre foi amputado para evitar necrose, ainda com o animal anestesiado.

\subsection{Técnica de exercitação}

O exercício utilizado foi a natação, e foi realizado em um reservatório de 500 litros de água, circular, fabricado em fibra de vidro e com profundidade de 60cm (Figura 5) 


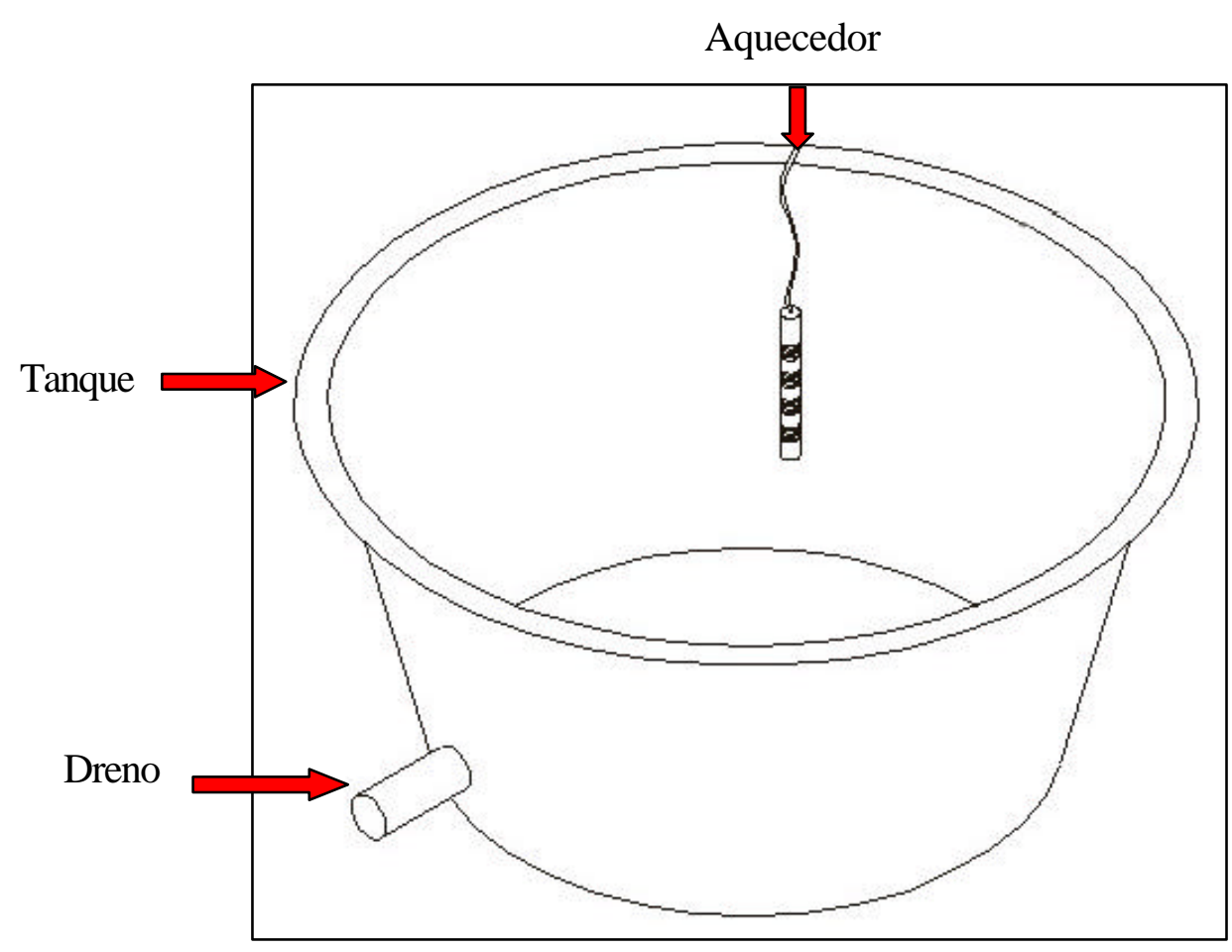

FIGURA 5 - Esquema ilustrativo do tanque com o aquecedor e o cano de drenagem da água.

A temperatura da água foi mantida entre $32^{\circ} \mathrm{C}$ e $34^{\circ} \mathrm{C}$ por meio de um aquecedor de aquário, ligado a um termostato, e o nível da água mantido de tal forma que o animal não conseguisse se apoiar no fundo nem se agarrar à beirada do tanque.

O treinamento foi realizado por um período de 30 dias, uma hora ao dia, utilizando-se apenas do peso do animal. O exercício foi realizado entre 10 horas e 15 horas, 5 dias por semana, com descanso nos finais de semana.

Para a exercitação, as ratas foram simplesmente colocadas na água e vigiadas para evitar que usassem artifícios para descansar, como manterem-se imóveis ou apoiarem-se na borda do tanque.

Após cada sessão o animal era secado com jato de ar quente por um período de 30 minutos e colocado em gaiola de comum, com serragem no fundo e livre acesso à água e à ração, onde ficava até o próximo período de natação.

Após o término do período de cada grupo os animais eram sacrificados com inalação excessiva de éter sulfúrico. 


\subsection{Coleta de material}

Após o sacrifício o membro posterior direito foi usado para avaliação. Previamente, a pele da coxa foi retirada, o músculo tensor da fáscia lata removido e realizada abordagem do músculo gastrocnêmio (Figura 6), que foi isolado, mas preservando suas origens ósseas no terço distal do fêmur e na inserção no calcâneo. O segmento distal do fêmur e a pata foram mantidos para serem usados como fixação nos acessórios da máquina de ensaio. Em seguida, as peças foram colocadas em solução de lactato de Ringer, em temperatura ambiente, até o momento do ensaio que ocorreu, no máximo, até 60 minutos pós-morte.

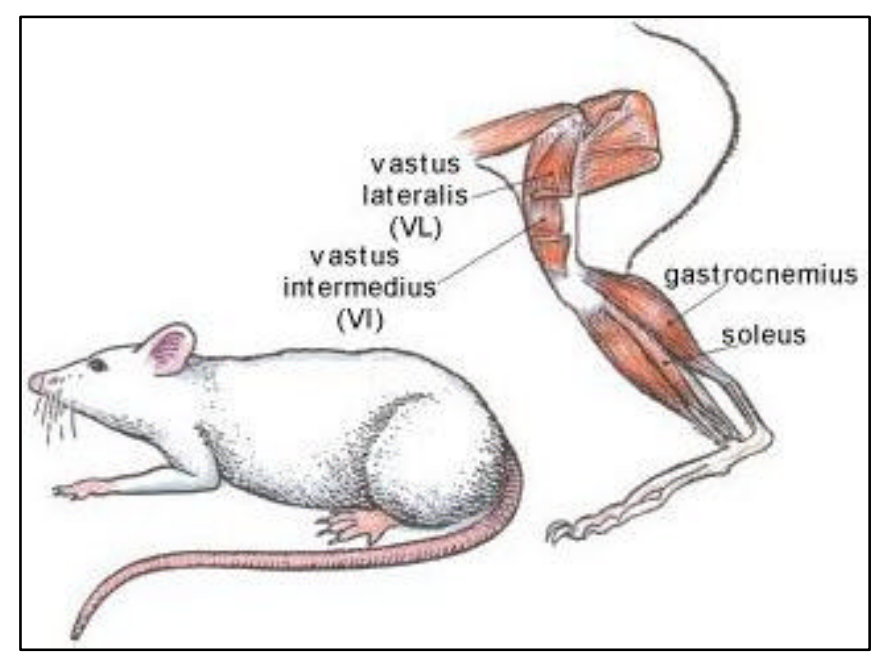

FIGURA 6 - Desenho esquemático mostrando detalhes anatômicos do músculo gastrocnêmio do rato (in http://www.nsbri.org/humanphysiologyspace/focus5/ references.html).

\subsection{Ensaio mecânico de tração}

Para o ensaio de tração do músculo gastrocnêmio foi utilizada a máquina universal de ensaio mecânico do Laboratório de Bioengenharia da Faculdade de Medicina de Ribeirão 
Preto - USP, equipada com célula de carga de $200 \mathrm{kgf}\left(\operatorname{Kratos}^{\circledR}\right)$, ligada a uma ponte de extensometria $\left(\operatorname{Sodmex}^{\circledR}\right)$.

As deformações foram fornecidas por um relógio comparador (Mitutoyo ${ }^{\circledR}$ ), com precisão de $0,01 \mathrm{~mm}$.

Para a fixação do músculo foram utilizados dois acessórios metálicos confeccionados na Oficina Mecânica de Precisão do Campus da Universidade de São Paulo - Ribeirão Preto, sendo um para o fêmur e, outro, para o calcâneo, de modo a manter o músculo gastrocnêmio formando um ângulo de $90^{\circ}$ com o fêmur e com o calcâneo (Figura 7).

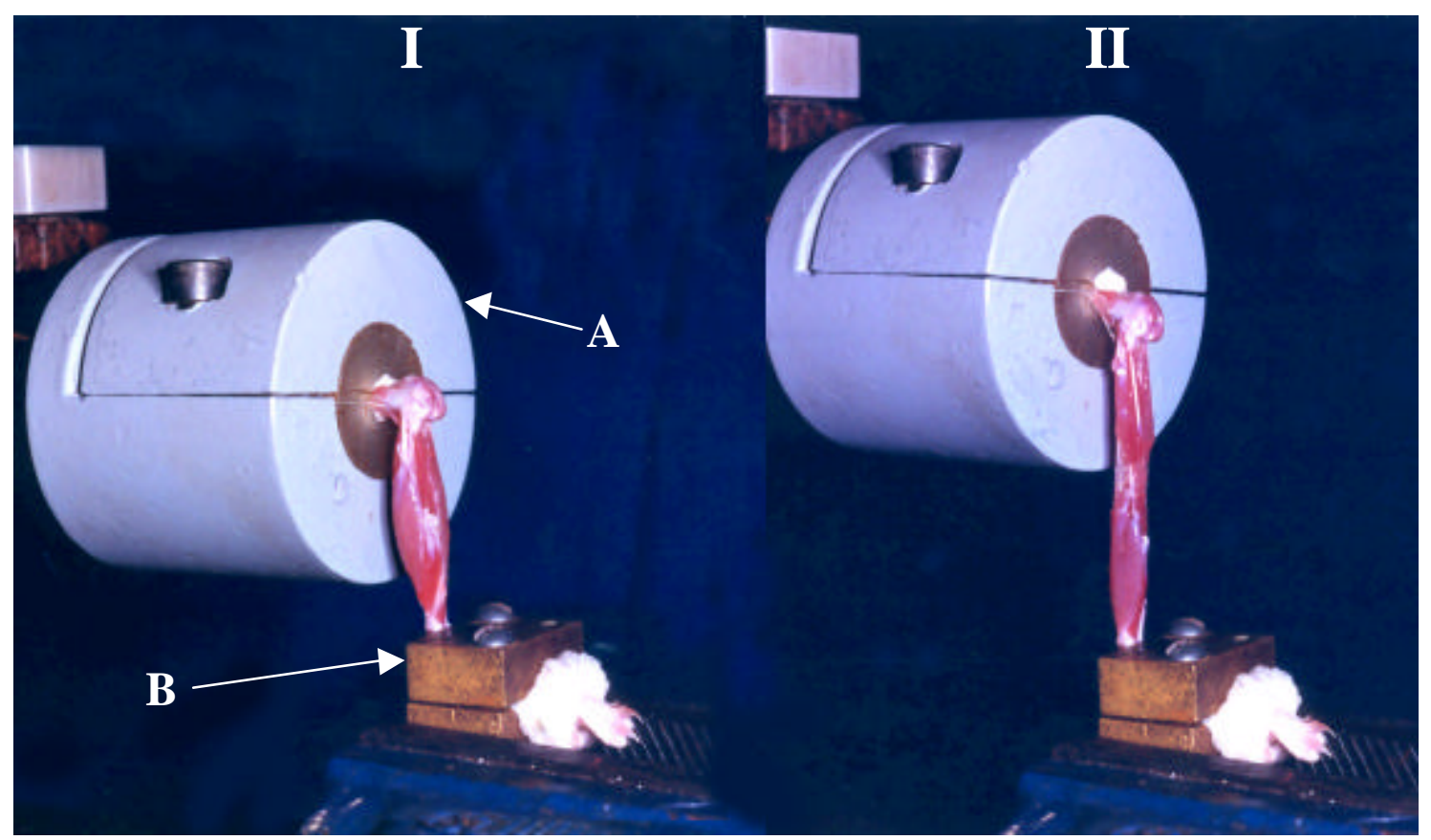

FIGURA 7 - Detalhe do músculo gastrocnêmio sendo submetido ao ensaio de tração em uma fase inicial (I) e final (II), ilustrando o acessório para fixação do fêmur (A) e do acessório para fixação do calcâneo $(B)$. Notar o posicionamento do músculo perpendicularmente às inserções e o alongamento sofrido pelo músculo após o ensaio.

Os músculos foram ensaiados logo após serem isolados, sendo fixados aos acessórios e submetidos à tração axial. Durante o ensaio a peça anatômica foi borrifada com solução de lactato de Ringer para evitar dessecação.

Foi aplicada uma pré-carga de $200 \mathrm{~g}$, durante 60 segundos, para acomodação do sistema. A velocidade estabelecida foi de $5 \mathrm{~mm} / \mathrm{min}$, e a carga aplicada foi registrada a cada 
0,5mm de deformação, até a ruptura do músculo, sendo examinados e observados os locais das rupturas quanto à localização. Só foram considerados os ensaios onde a ruptura ocorreu no ventre muscular.

\subsubsection{Propriedades mecânicas}

Com a obtenção dos valores de carga $x$ deformação em cada ensaio, foram confeccionados os gráficos (carga aplicada $x$ deformação), com auxílio do programa de computador EXCEL $7^{\circledR}$.

Com esses gráficos foram obtidas as seguintes propriedades mecânicas: carga e deformação no limite da proporcionalidade [LP], carga e deformação máximas [LM] e rigidez [R].

Um gráfico teórico da obtenção dos parâmetros está ilustrado na Figura 8.

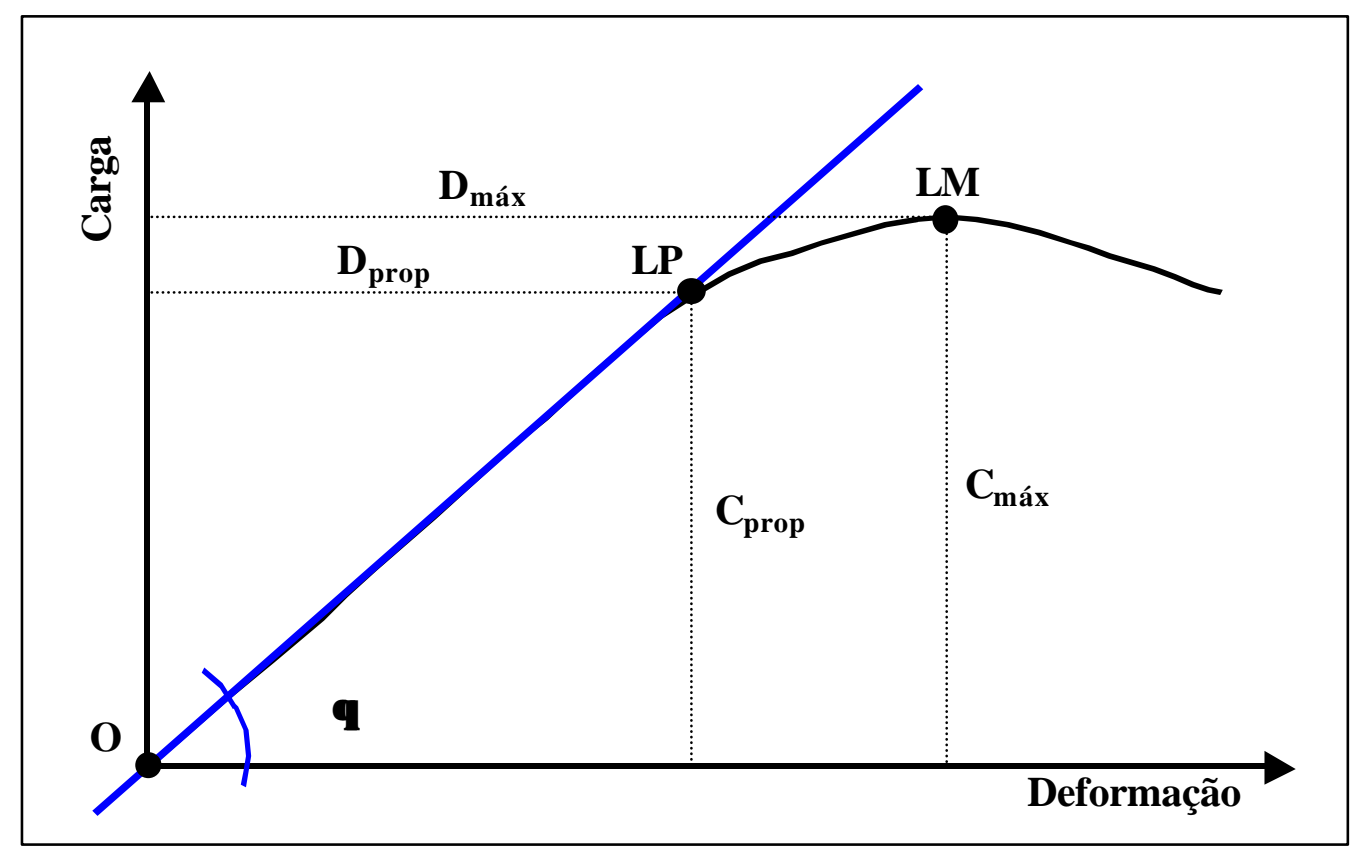

FIGURA 8 - Gráfico carga $x$ deformação ilustrando os pontos de obtenção das propriedades mecânicas com o ensaio de tração. Dmáx = deformação máxima; $L M=$ limite máximo; Dprop.= deformação proporcional; $\mathbf{L P}=$ limite de proporcionalidade; $\mathrm{Cprop}=$ carga proporcional; Cmáx = carga máxima; $\theta$ = ângulo de inclinação da reta 


\subsubsection{Limite de proporcionalidade (LP)}

O limite de proporcionalidade foi considerado como sendo o ponto da extremidade distal do segmento linear do gráfico carga $x$ deformação que foi obtido por uma curva de regressão, seguindo a inclinação e identificando, a extremidade da reta. As coordenadas desse ponto representam a carga e a deformação no limite de proporcionalidade.

\subsubsection{Limite máximo (LM)}

O limite máximo é o maior valor da carga e deformação observados a cada ensaio, até o rompimento do músculo.

\subsubsection{Rigidez $(R)$}

A rigidez é obtida na fase elástica do material, determinada pela inclinação da curva carga $x$ deformação, calculada pela tangente do ângulo $\theta$ formado pela reta que representa a inclinação da curva na fase elástica em relação ao eixo das abscissas.

$$
R=T g \theta=\frac{\mathrm{C}_{\text {Prop }}}{\mathrm{D}_{\text {Prop }}}
$$

\subsection{Análise Estatística}

A normalidade da distribuição dos valores intra-grupos foi avaliada pelo teste de Kolmogorov e Smirnov. A comparação entre os grupos com distribuição normal foi feita pelo teste ANOVA ("One-way Analysis of Variance") e a verificação dos grupos que apresentaram diferença, pelo teste de múltiplas comparações de Tukey-Kramer. As comparações entre dois grupos foram feitas por intermédio do teste não pareado "t" de 
Student. Os cálculos foram realizados utilizando-se do pacote estatístico SPSS-10 for Windows $^{\circledR}$. Foi considerado o nível de $5 \%$ como de significância estatística. 


\section{RESULTADOS}

\subsection{ANIMAIS}

Os grupos, inicialmente, foram planejados para conter 15 animais em cada um deles. Entretanto, houve algumas mortes durante o experimento ou perdas de peças por falhas técnicas durante o ensaio.

A Tabela 1 apresenta o número de animais que foram incluídos no estudo e os valores médios \pm desvio padrão de peso ao início e final dos experimentos. Os Anexos de 1 a 7 apresentam os valores individuais.

Tabela 1 - Número de animais e peso (média \pm desvio padrão) antes e após os respectivos tratamentos.

\begin{tabular}{ccccc}
\hline $\begin{array}{c}\text { Grupo de } \\
\text { Estudo }\end{array}$ & N & Peso inicial $(\mathrm{g})$ & $\begin{array}{c}\text { Peso ao final da } \\
\text { suspensão }(\mathrm{g})\end{array}$ & $\begin{array}{c}\text { Peso ao final da } \\
\text { natação }(\mathrm{g})\end{array}$ \\
\hline Controle & 12 & $263,7 \pm 14,8$ & & \\
& & & & \\
Suspensão & & & & \\
7 dias & 11 & $246,4 \pm 16,7^{\mathrm{a}}$ & $234,5 \pm 19,7$ & \\
14 dias & 14 & $247,9 \pm 13,1^{\mathrm{a}}$ & $238,9 \pm 15,8$ & \\
21 dias & 12 & $262,1 \pm 22,4$ & $258,8 \pm 29,3$ &
\end{tabular}

Suspensão seguida de 30 dias de natação

$\begin{array}{rrccc}7 \text { dias } & 13 & 234,2 \pm 8,6^{\mathrm{a}, \mathrm{c}} & 226,5 \pm 12,5^{\mathrm{b}} & 255,8 \pm 23,7 \\ 14 \text { dias } & 15 & 244,0 \pm 12,3^{\mathrm{a}, \mathrm{c}} & 224,7 \pm 13,2^{\mathrm{b}} & 259,0 \pm 22,5 \\ 21 \text { dias } & 14 & 256,1 \pm 16,1 & 248,9 \pm 23,1^{\mathrm{b}} & 264,3 \pm 25,6\end{array}$

${ }^{a}$ Diferença estatisticamente significativa $(p<0,05)$ entre os pesos iniciais e ao fim do período de suspensão.

${ }^{b}$ Diferença estatisticamente significativa $(\mathrm{p}<0,05)$ entre os pesos ao fim do período de suspensão e após 30 dias de natação. dias de natação.

c Diferença estatisticamente significativa $(\mathrm{p}<0,05)$ entre os pesos iniciais e após 30

Quanto ao peso inicial dos animais, o menor animal incluído pesou $210 \mathrm{~g}$ e o maior 295 g. Apesar de estar dentro do critério de inclusão, o grupo de animais suspensos por 7 dias 
seguidos de natação apresentou peso estatisticamente menor que as ratas do grupo controle e das suspensas por 21 dias (seguido ou não de natação). No Anexo I encontram-se listados os pesos individuais dos animais estudados.

Após a suspensão dos animais por sete ou 14 dias houve diminuição significativa dos seus pesos. No entanto, a perda de peso dos animais submetidos 21 dias de suspensão só atingiu significância estatística $(\mathrm{p}=0,047)$ quando, para efeito de análise, foram juntadas os dois grupos que foram submetidos a esse tratamento.

A Figura 9 apresenta os valores dos pesos dos animais controle ao início e final dos diversos períodos de suspensão.

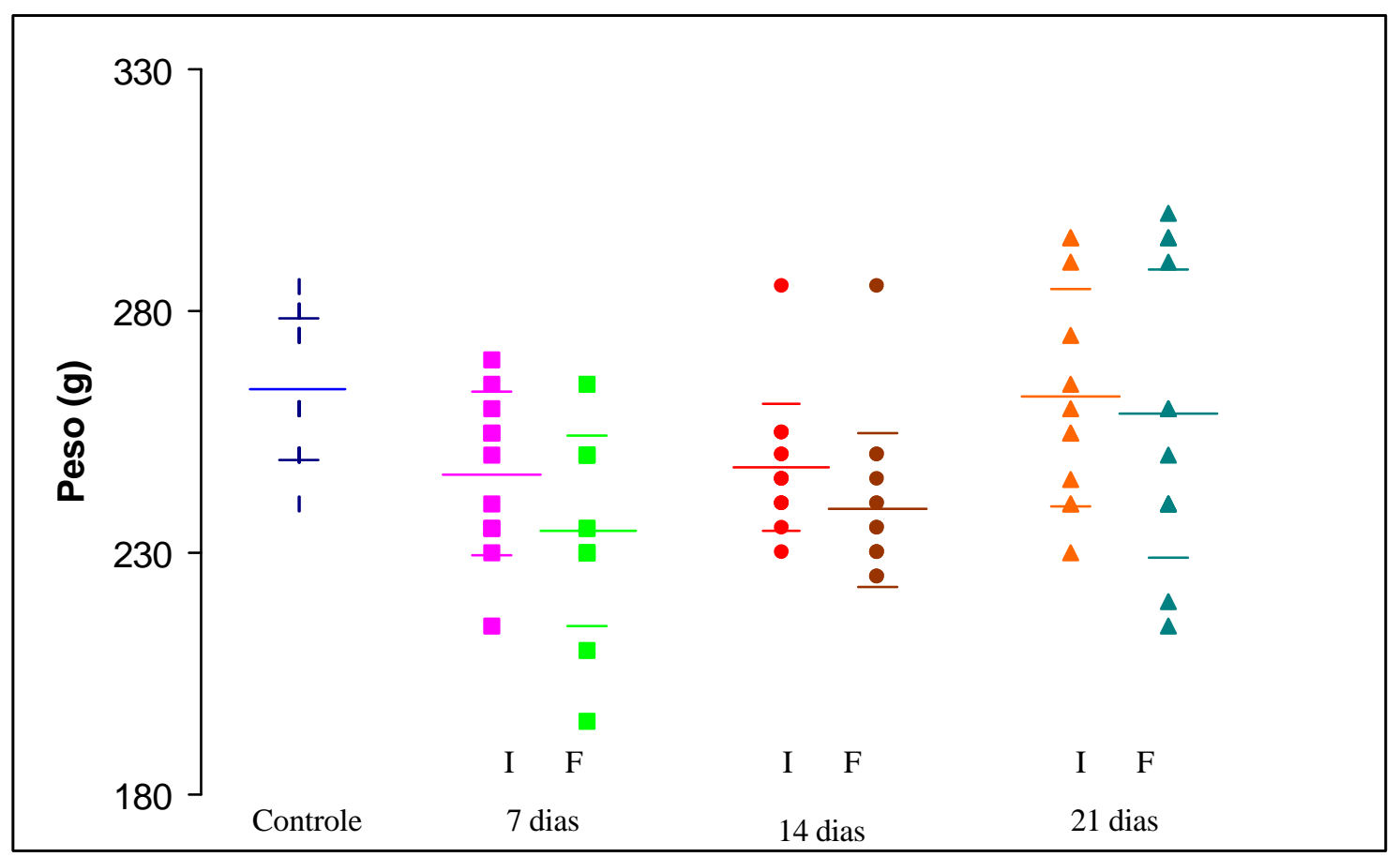

FIGURA 9 - Valores dos pesos dos animais controle e ao início ( I ) e final ( F ) de 7, 14 e 21 dias de suspensão.

Quanto aos animais submetidos à natação por 30 dias, os três grupos apresentaram aumento estatisticamente significante de peso $(\mathrm{p}<0,001)$ quando se comparam os pesos no término do período de suspensão e no término do período de natação. Quando se compara o 
peso inicial (antes da suspensão) e final (após a natação) encontra-se que nos grupos de animais suspensos por sete ou 14 dias ocorreu aumento de peso $(\mathrm{p}=0,004$ para sete dias e $\mathrm{p}=$ 0,003 para 14 dias), porém, para os animais suspensos por 21 dias o aumento de peso ocorrido após a natação não atingiu significância estatística.

A Figura 10 apresenta os valores dos pesos dos animais controle, no início e final dos diversos períodos de suspensão, seguidos de 30 dias de natação.

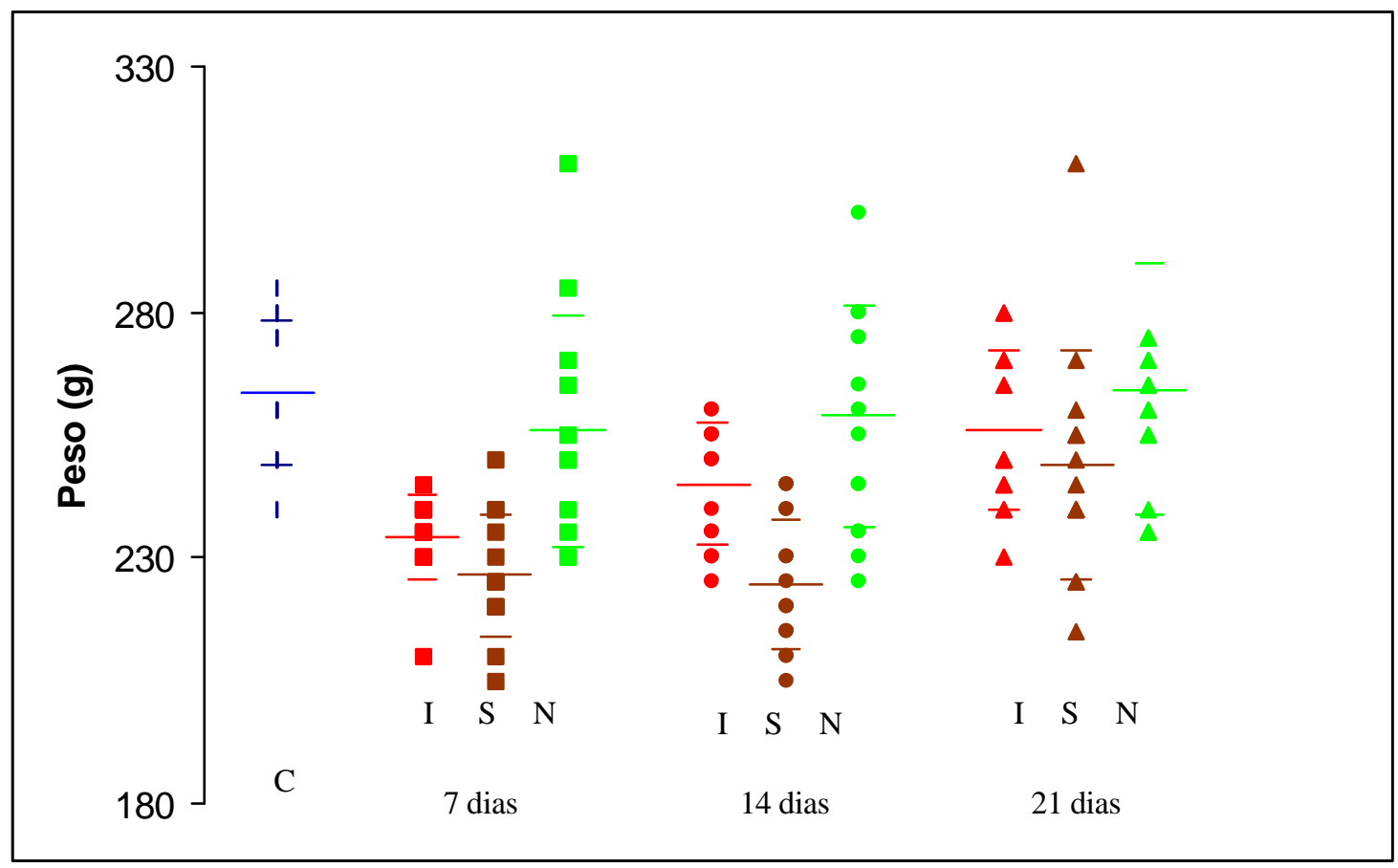

FIGURA 10 - Valores dos pesos dos animais controle e ao início ( I ) e final ( S ) de 7, 14 e 21 dias de suspensão, seguidos de 30 dias de natação $(\mathrm{N})$. 


\subsection{PROPRIEDADES MECÂNICAS}

\subsubsection{Ensaios mecânicos:}

Os valores individuais obtidos durante os ensaios mecânicos podem ser encontrados nos Anexos de oito a catorze. As curvas dos ensaios mecânicos realizados com o músculo gastrocnêmio dos animais do grupo controle encontram-se na Figura 11. Para tornar mais homogênea a visualização das curvas foi calculada a média e erro padrão da média (EP) das diversas curvas conseguidas com os ensaios dos músculos dos animais controle, e o resultado encontra-se na Figura 12.

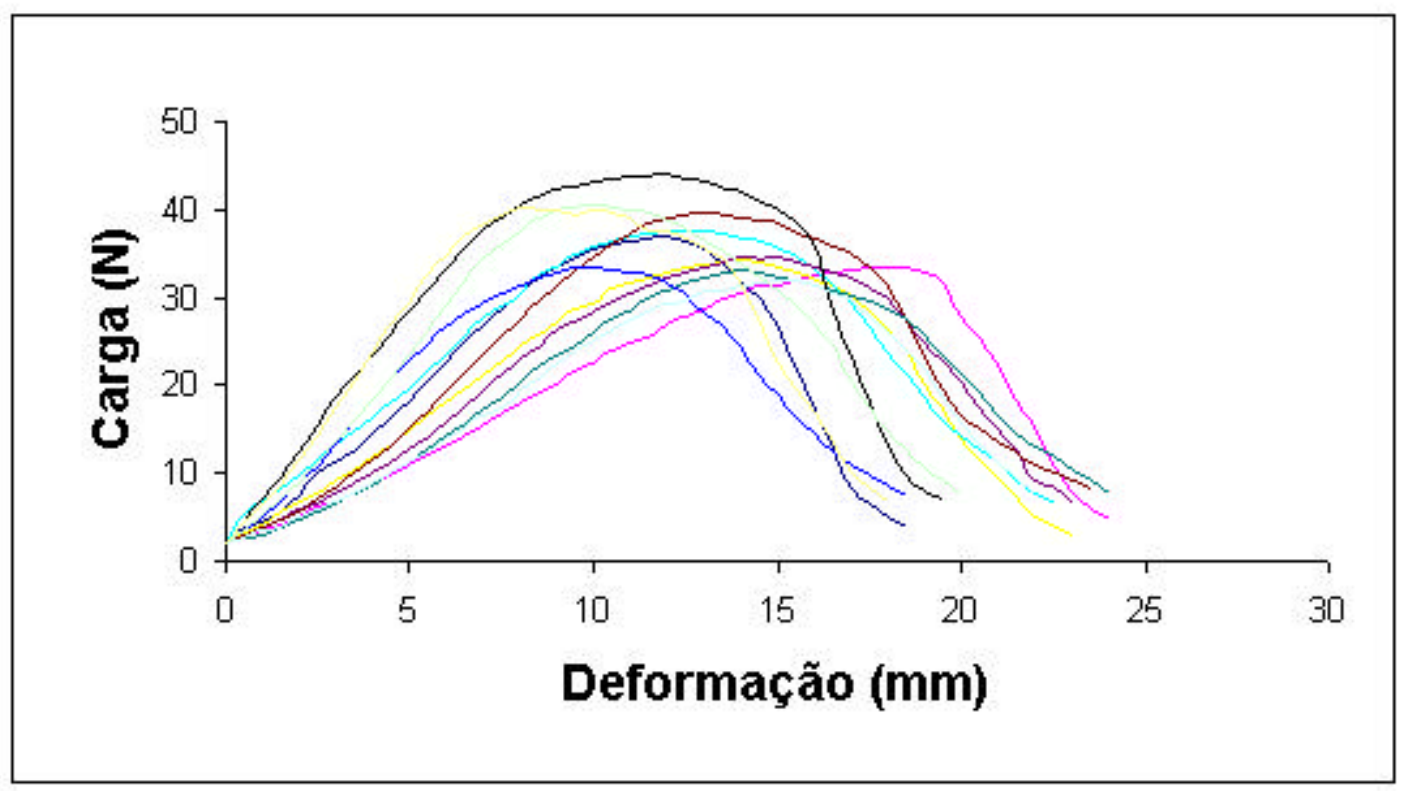

FIGURA 11 - Curvas Carga $x$ Deformação individuais dos músculos gastrocnêmios dos 12 animais-controle 


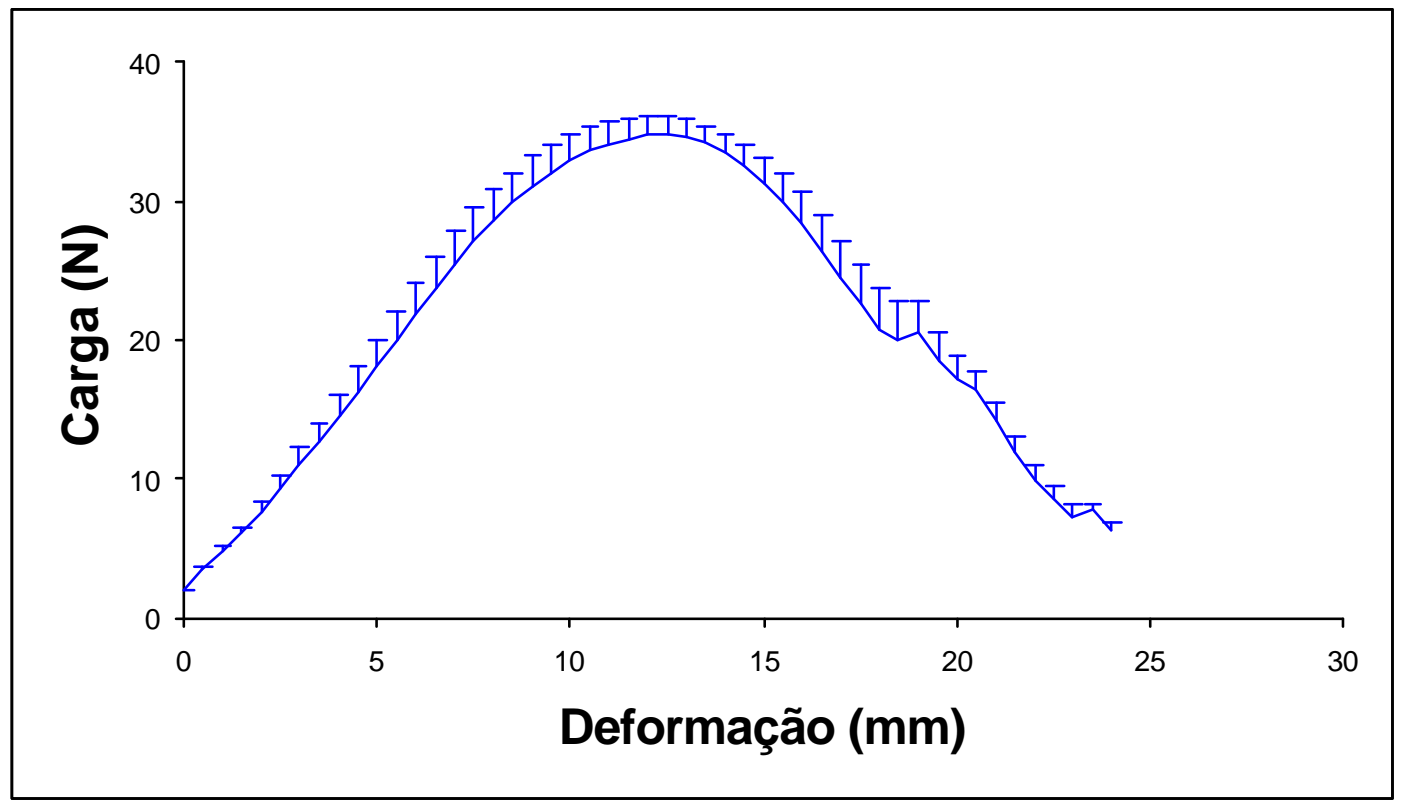

FIGURA 12 - Médias $\#$ EP das curvas Carga $x$ Deformação dos músculos gastrocnêmios dos 12 animais controle. 
Os ensaios mecânicos realizados com o músculo gastrocnêmio dos animais suspensos por 7 dias encontram-se na Figura 13. A média e o erro padrão da média (EP) das diversas curvas encontram-se na Figura 14.

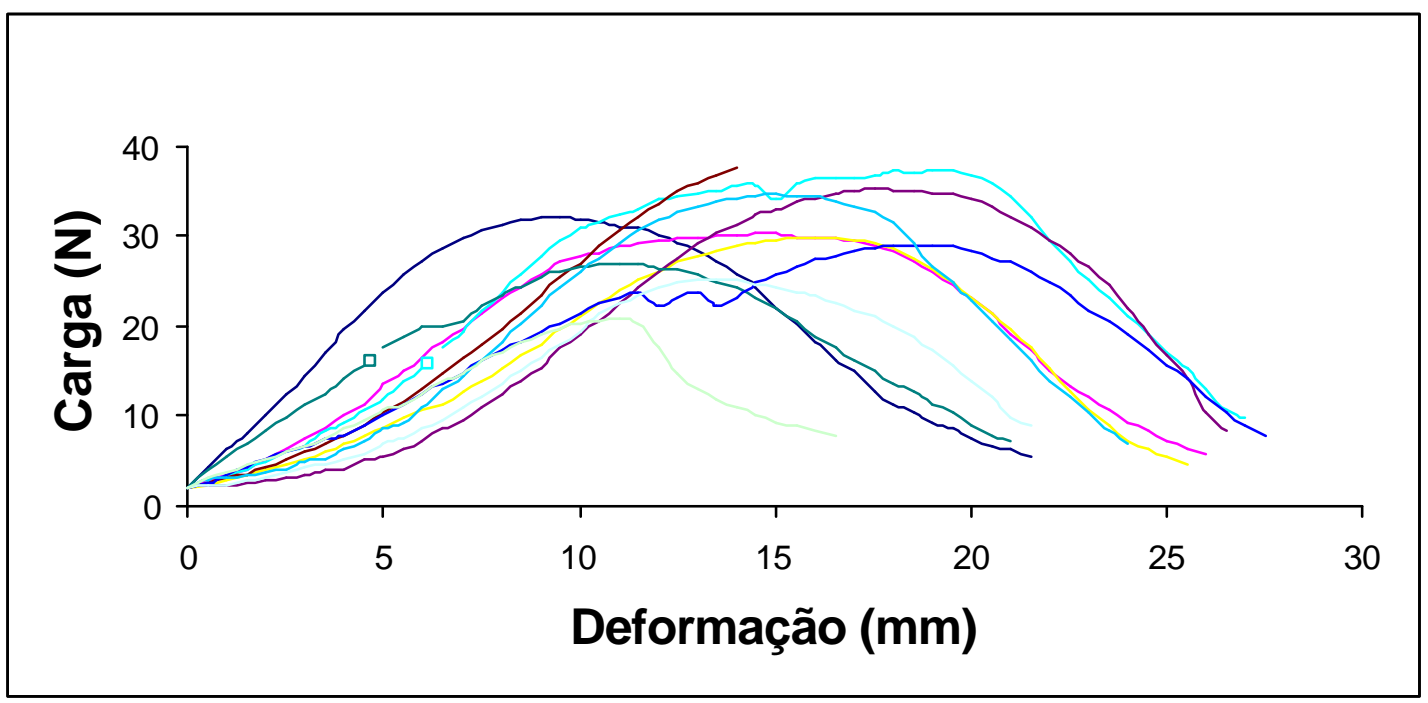

FIGURA 13 - Curvas Carga $x$ Deformação individuais dos músculos gastrocnêmios dos 11 animais suspensos por 7 dias

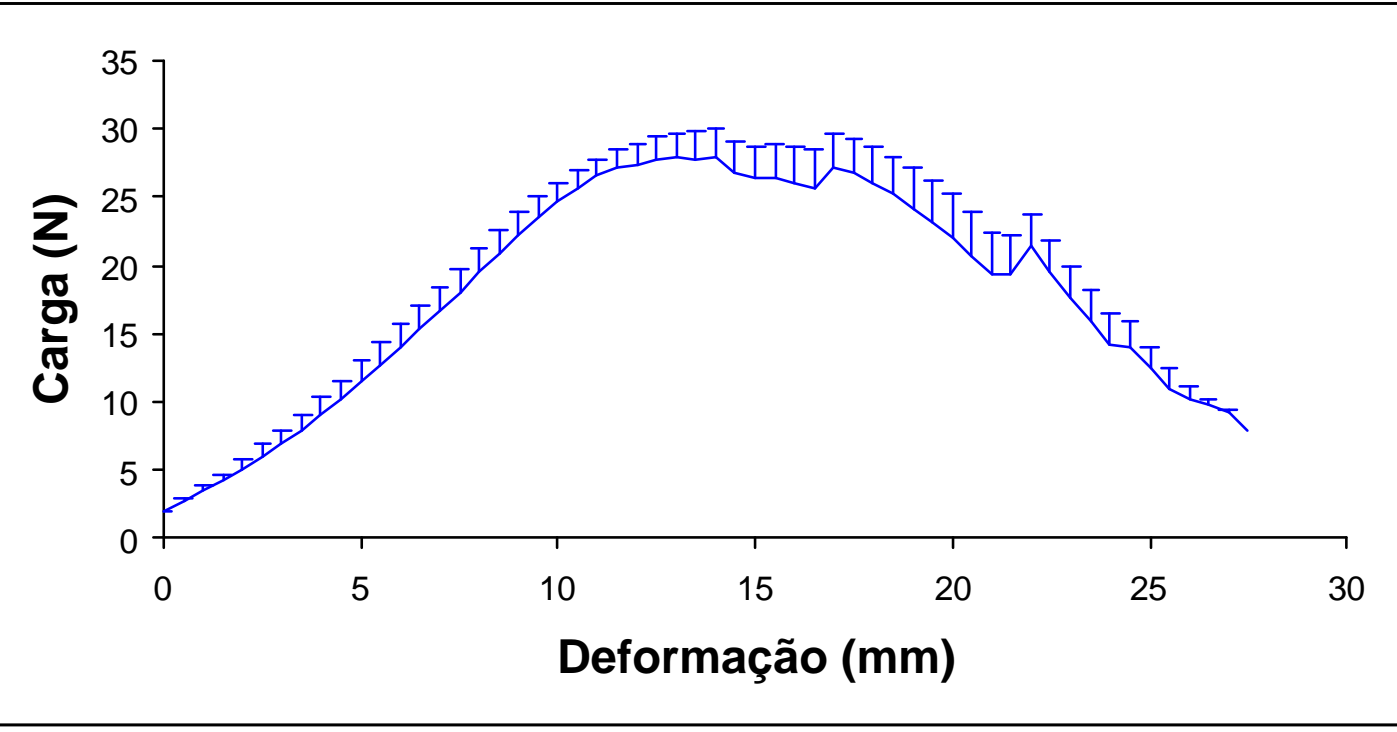

FIGURA 14 - Médias \pm EP das curvas Carga x Deformação dos músculos gastrocnêmios dos animais suspensos por 7 dias. 
Os ensaios mecânicos realizados com o músculo gastrocnêmio das ratas suspensas por 14 dias encontram-se na Figura 15. A média e o erro padrão da média (EP) das diversas curvas encontram-se na Figura 16.

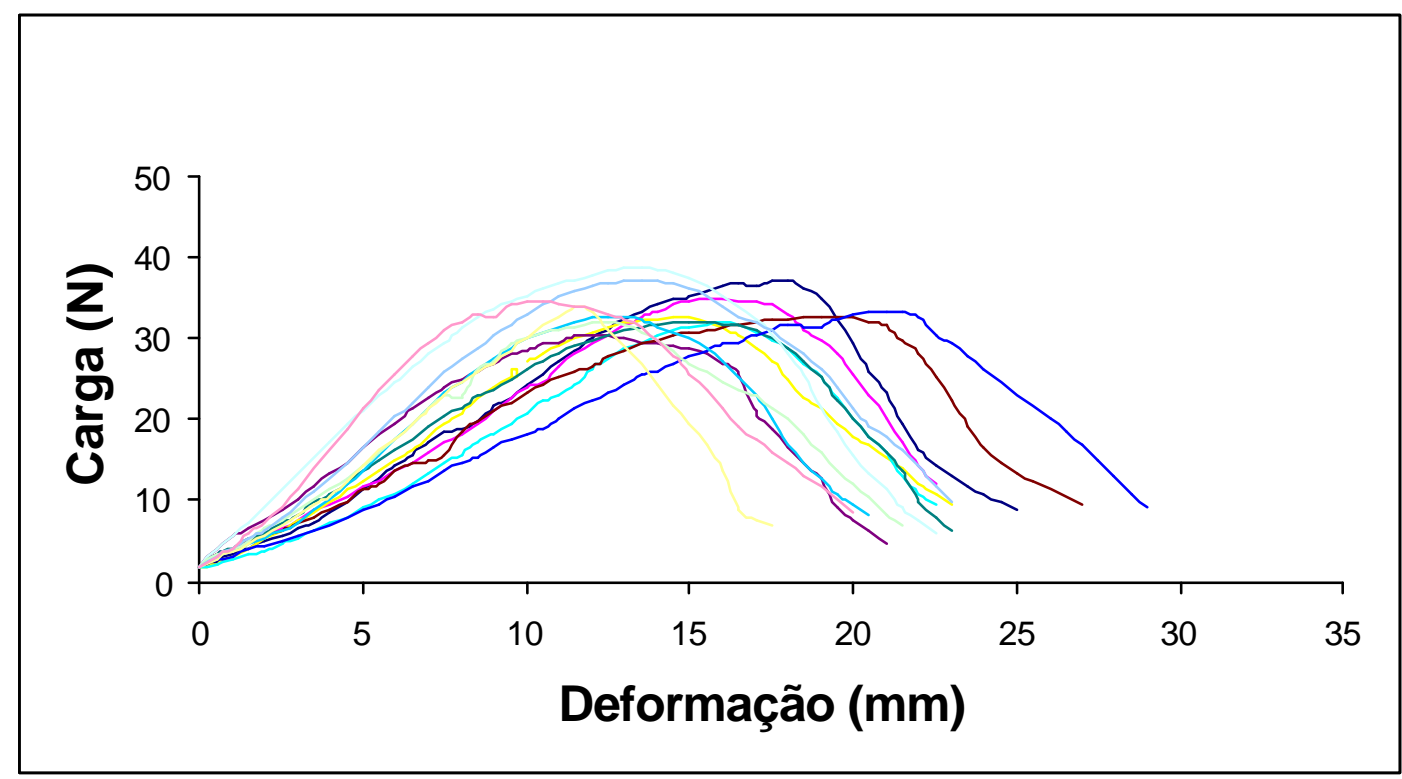

FIGURA 15 - Curvas Carga $x$ Deformação individuais dos músculos gastrocnêmios dos 14 animais suspensos por 14 dias

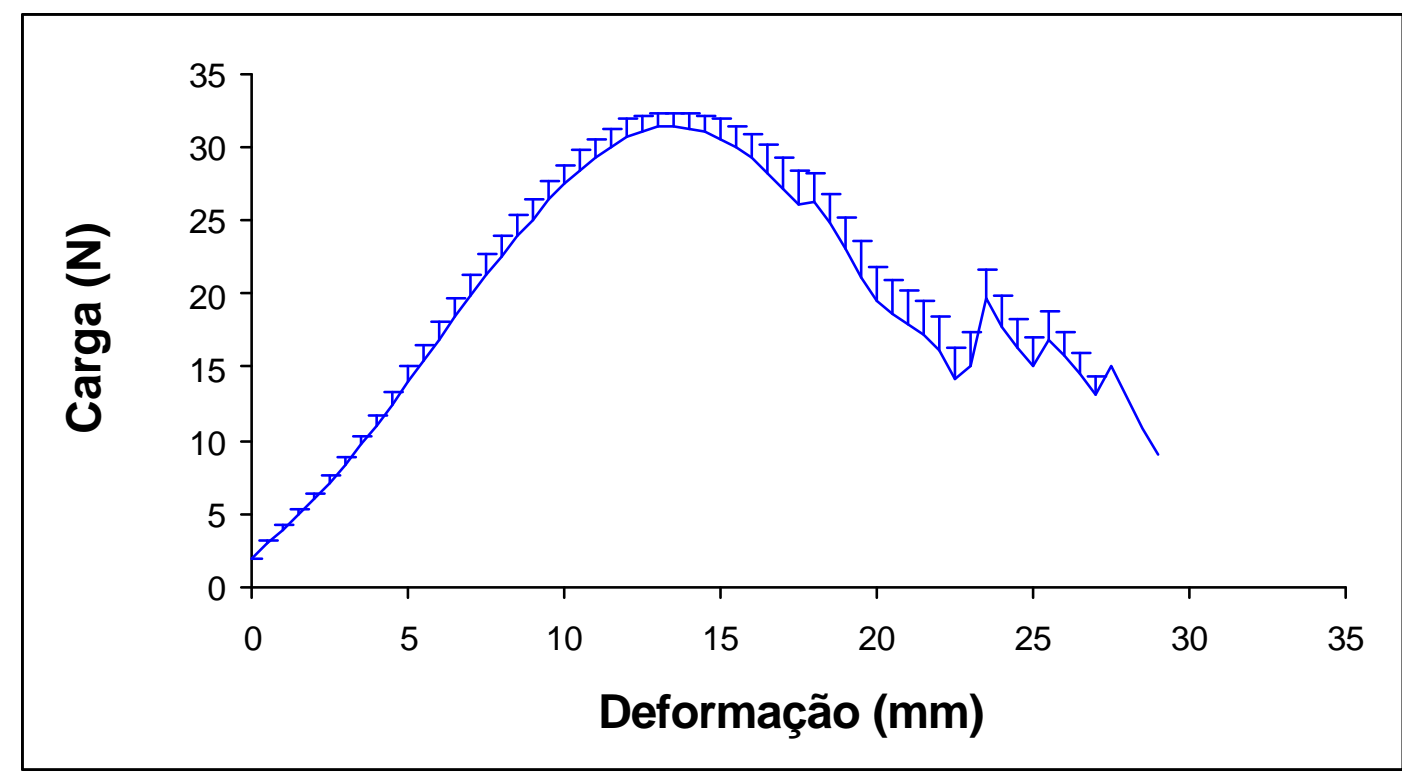

FIGURA 16 - Médias \pm EP das curvas Carga $x$ Deformação dos músculos gastrocnêmios dos animais suspensos por 14 dias. 
Os ensaios mecânicos realizados com o músculo gastrocnêmio dos 12 animais suspensos por 21 dias encontram-se na Figura 17. A média e o erro padrão da média (EP) das diversas curvas encontram-se na Figura 18.

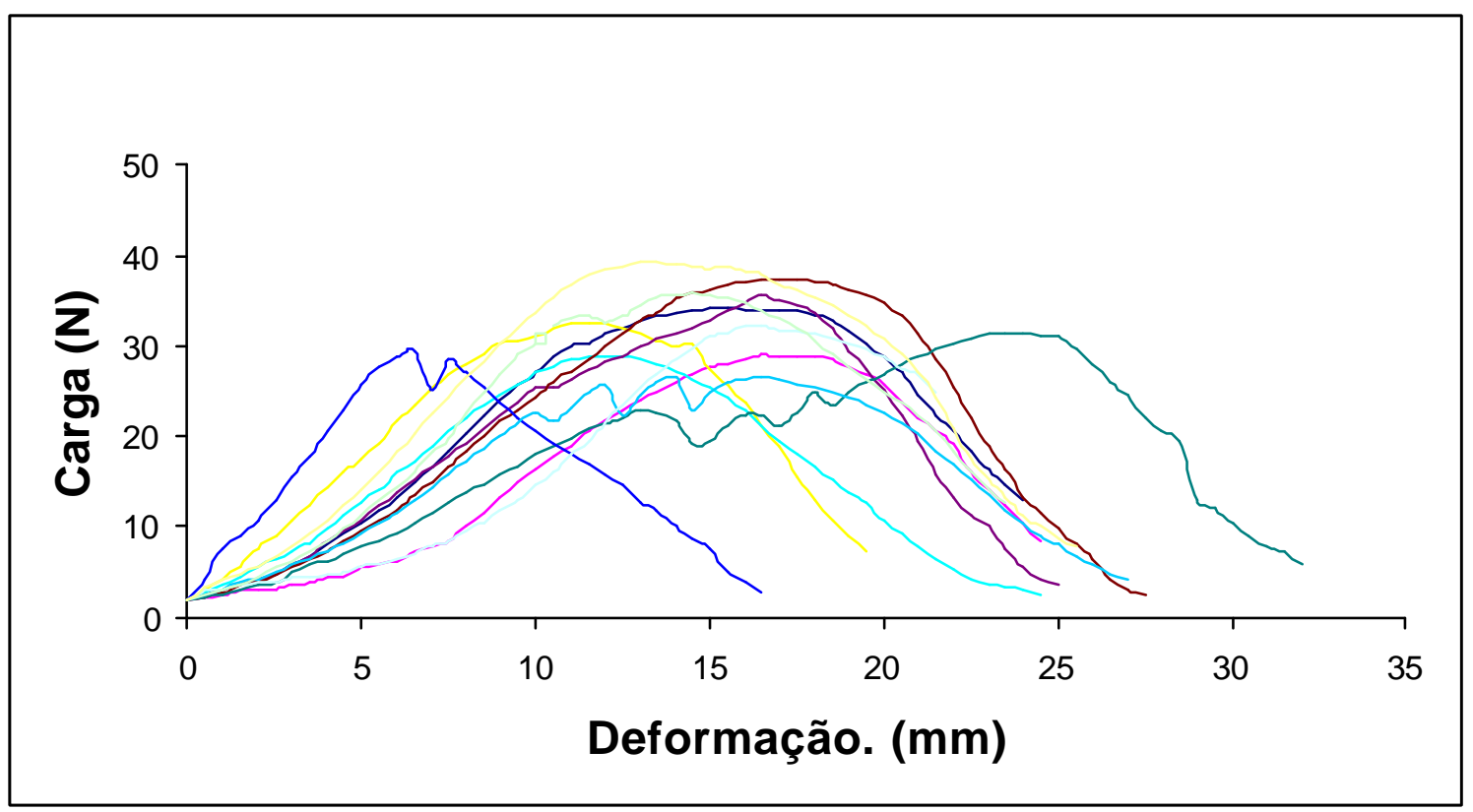

FIGURA 17 - Curvas Carga $x$ Deformação individuais dos músculos gastrocnêmios dos 12 animais suspensos por 21 dias.

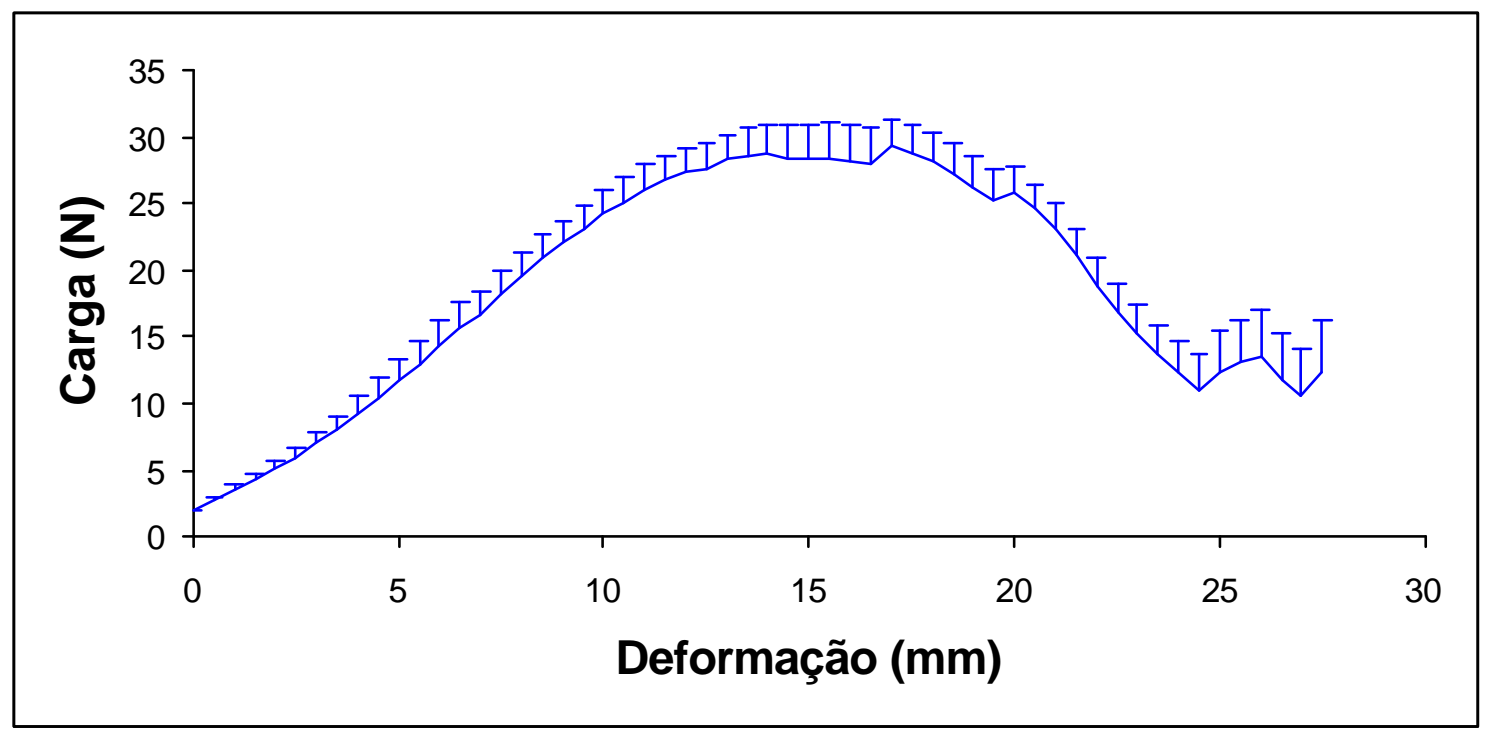

FIGURA 18 - Médias \pm EP das curvas Carga $x$ Deformação dos músculos gastrocnêmios dos animais suspensos por 21 dias. 
Os ensaios mecânicos realizados com o músculo gastrocnêmio das 13 ratas suspensas por 7 dias, seguidos de 30 dias de natação encontram-se na Figura 19. A média e o erro padrão da média (EP) das diversas curvas encontram-se na Figura 20.

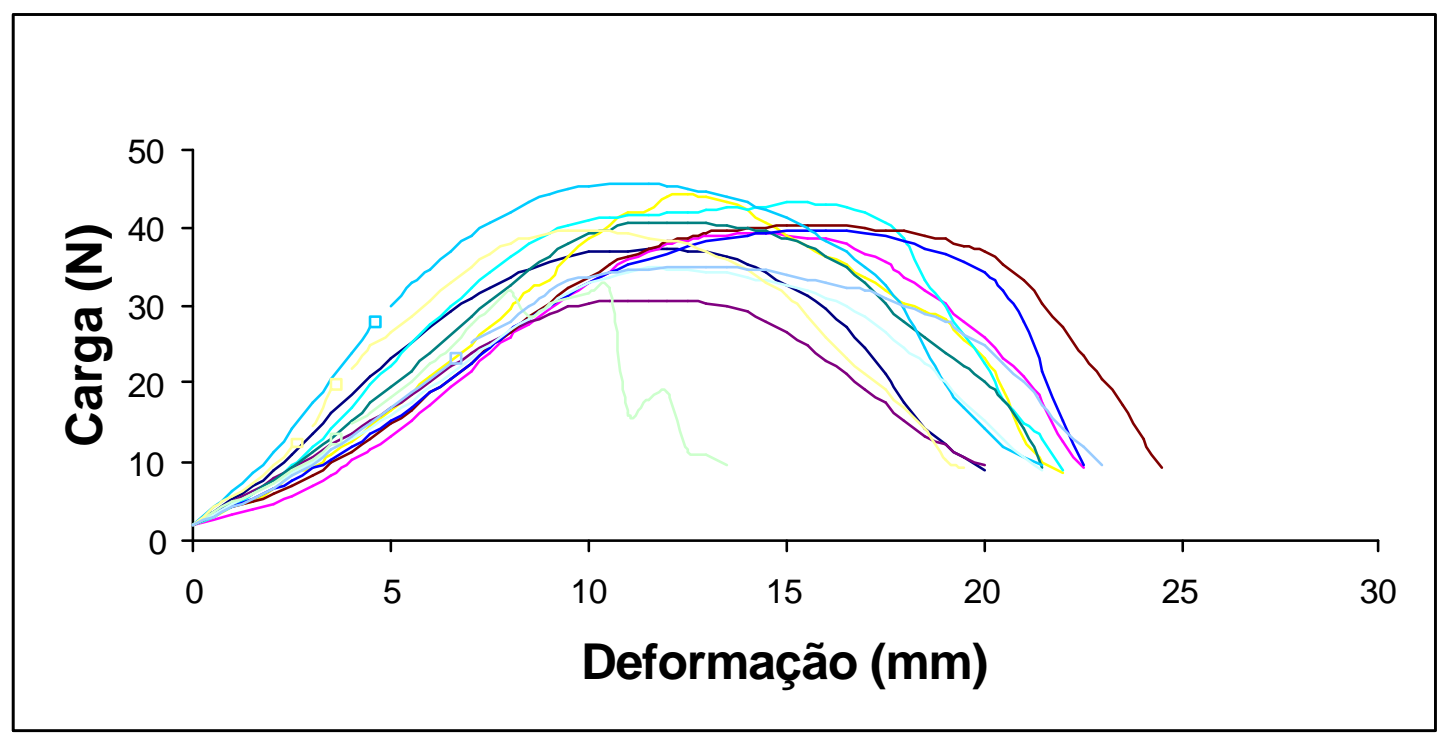

FIGURA 19 - Curvas Carga $x$ Deformação individuais dos músculos gastrocnêmios dos 13 animais suspensos por 7 dias, e seguidos de 30 dias de natação.

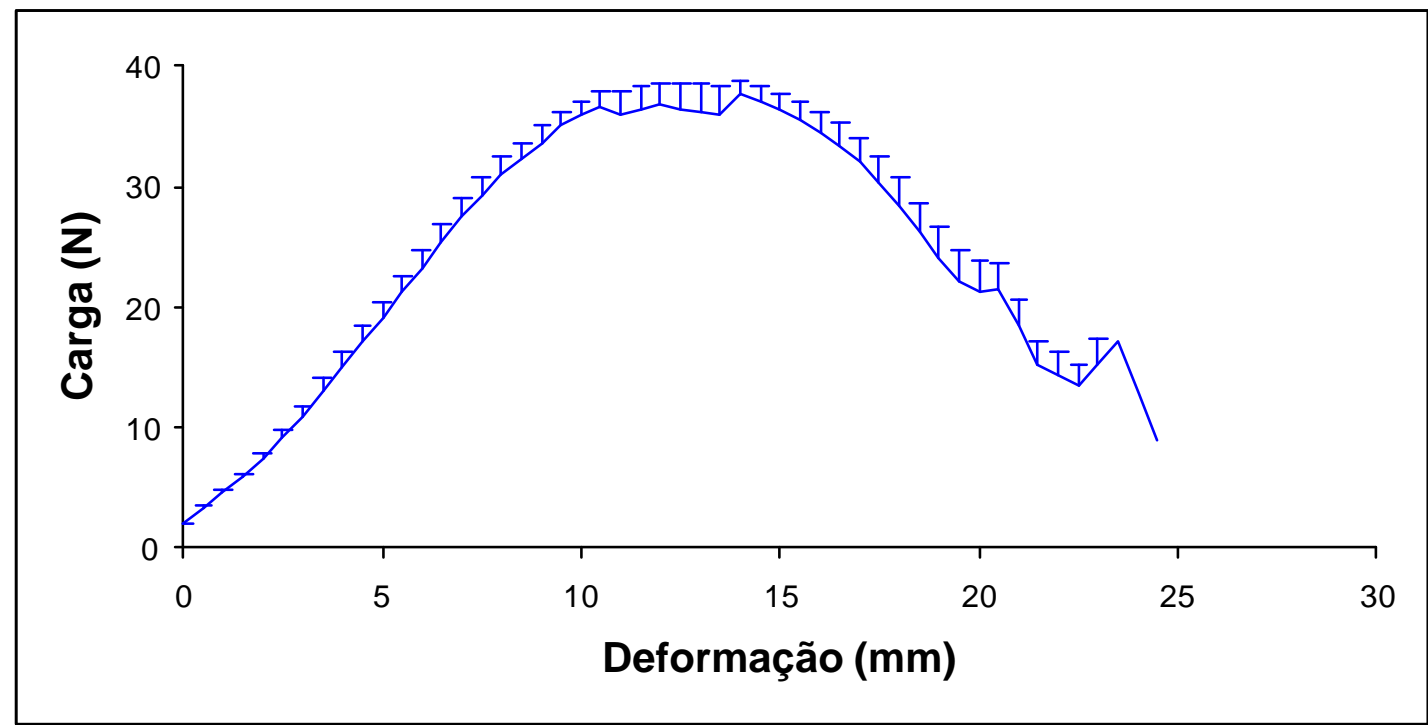

FIGURA 20 Médias \# EP das curvas Carga $x$ Deformação dos músculos gastrocnêmios dos animais suspensos por 7 dias, e seguidos de 30 dias de natação. 
Os ensaios mecânicos realizados com o músculo gastrocnêmio dos 15 animais suspensos por 14 dias, seguidos de 30 dias de natação encontram-se na Figura 21. A média e o erro padrão da média (EP) das diversas curvas encontram-se na Figura 22.

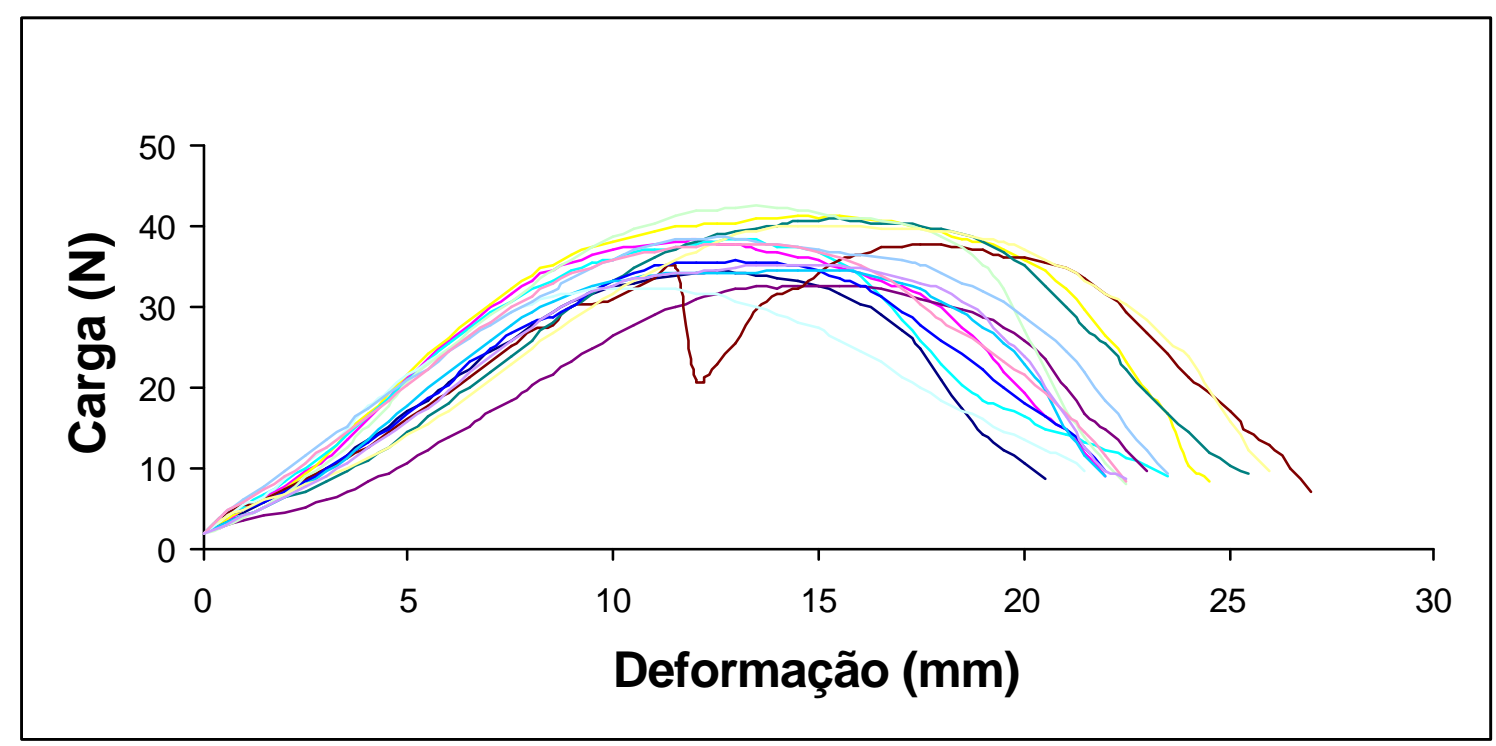

FIGURA 21 - Curvas Carga $x$ Deformação individuais dos músculos gastrocnêmios dos 15 animais suspensos por 14 dias, e seguidos de 30 dias de natação.

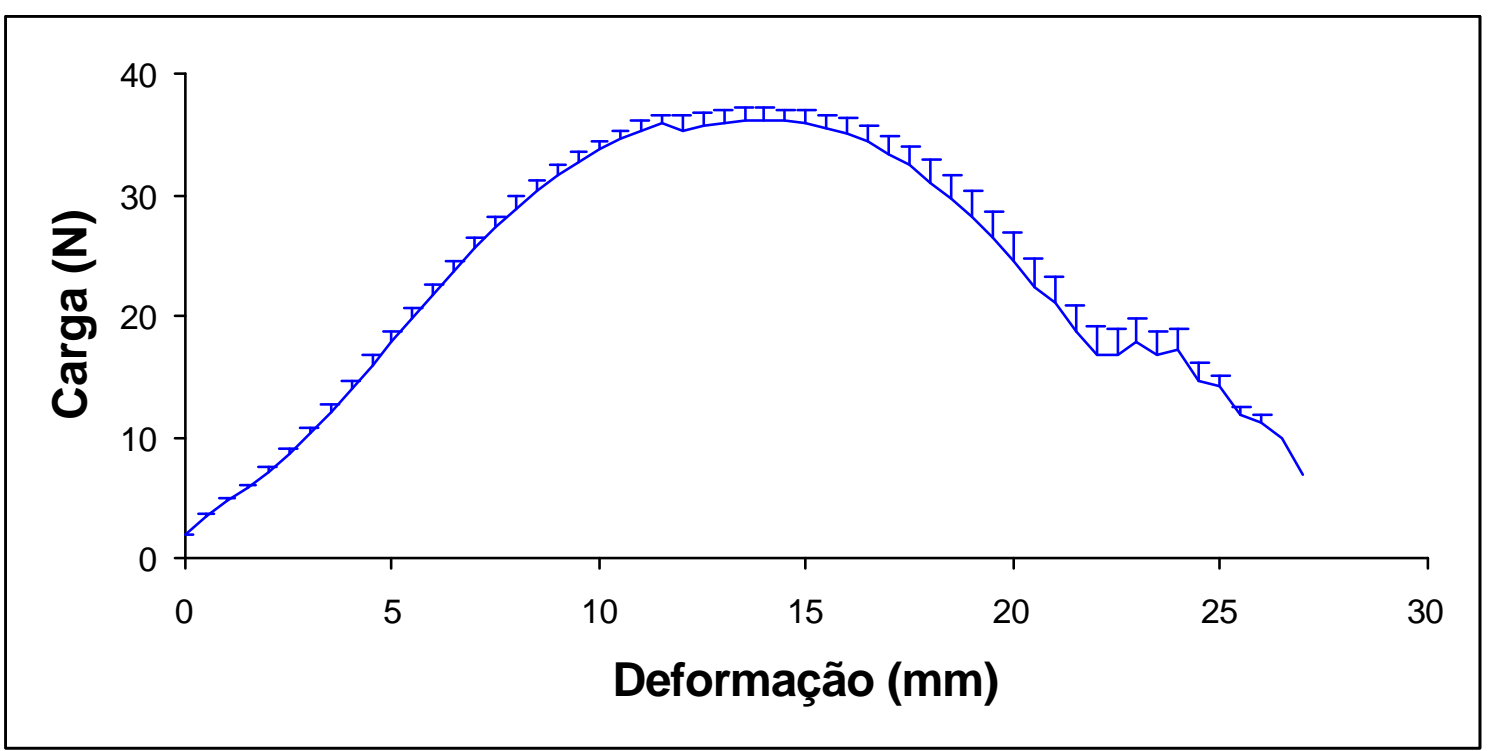

FIGURA 22 - Médias \# EP das curvas Carga $x$ Deformação dos músculos gastrocnêmios dos 15 animais suspensos por 14 dias, e seguidos de 30 dias de natação. 
Os ensaios mecânicos realizados com os músculos gastrocnêmios dos 14 animais suspensos por 21 dias, e seguidos de 30 dias de natação encontram-se na Figura 23. A média e o erro padrão da média (EP) das diversas curvas encontram-se na Figura 24.

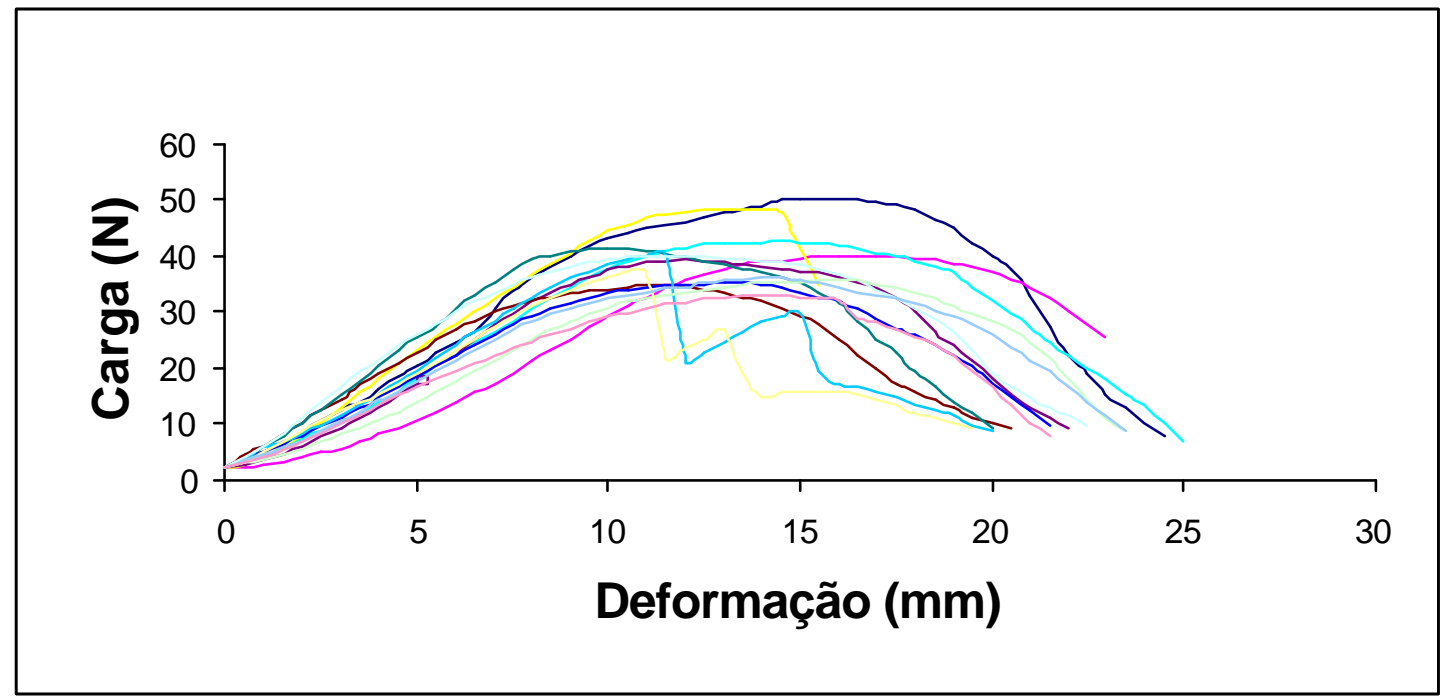

FIGURA 23 Curvas Carga $x$ Deformação individuais dos músculos gastrocnêmios dos 14 animais suspensos por 21 dias, e seguidos de 30 dias de natação.

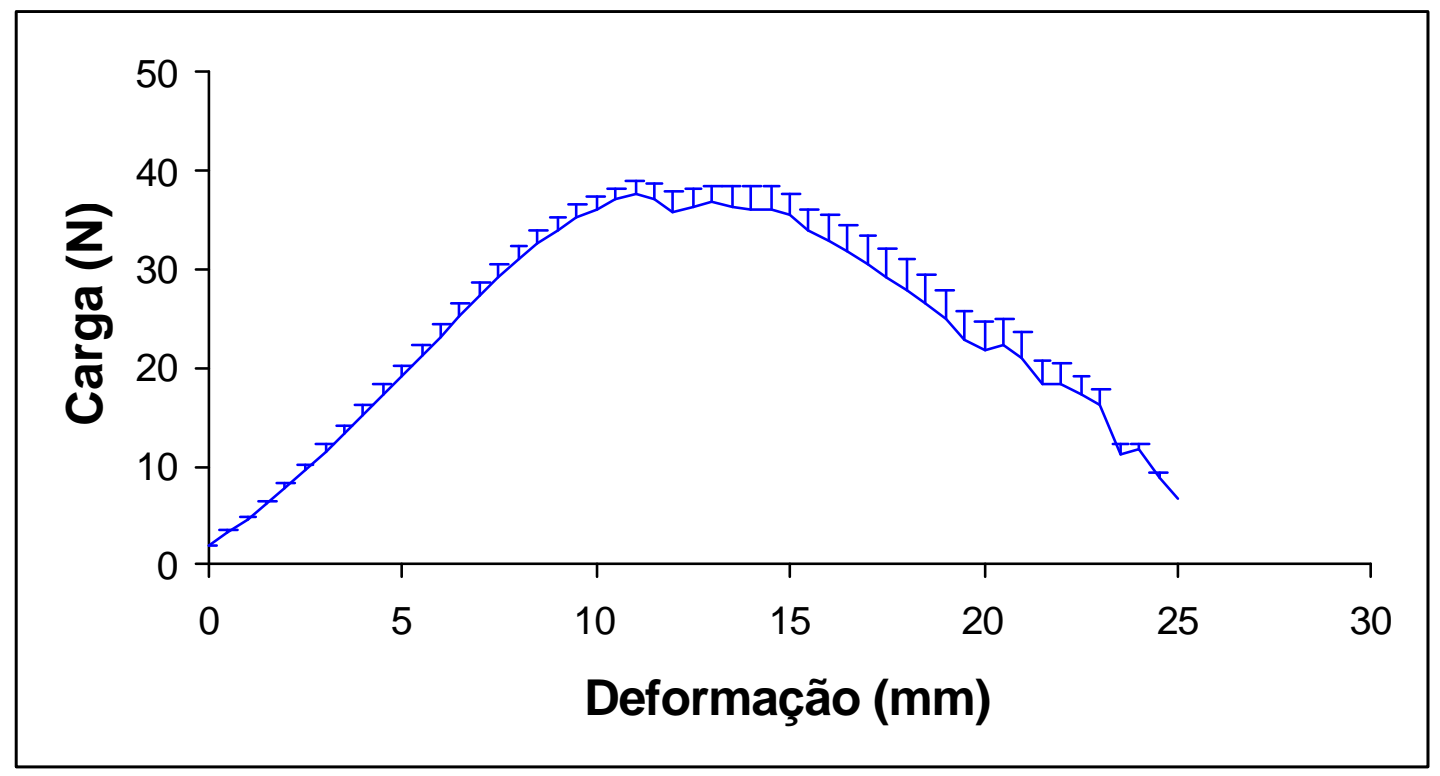

FIGURA 24 - Médias \pm EP das curvas Carga $x$ Deformação do músculo gastrocnêmio dos animais suspensos por 21 dias, seguidos de 30 dias de natação. 
A Figura 25 apresenta o comportamento dos músculos gastrocnêmio (médiaさEP) dos animais controle acompanhados dos suspensos pelos períodos de 7, 14 e 21 dias. Pode-se constatar que a curva do grupo controle destaca-se dos demais grupos.

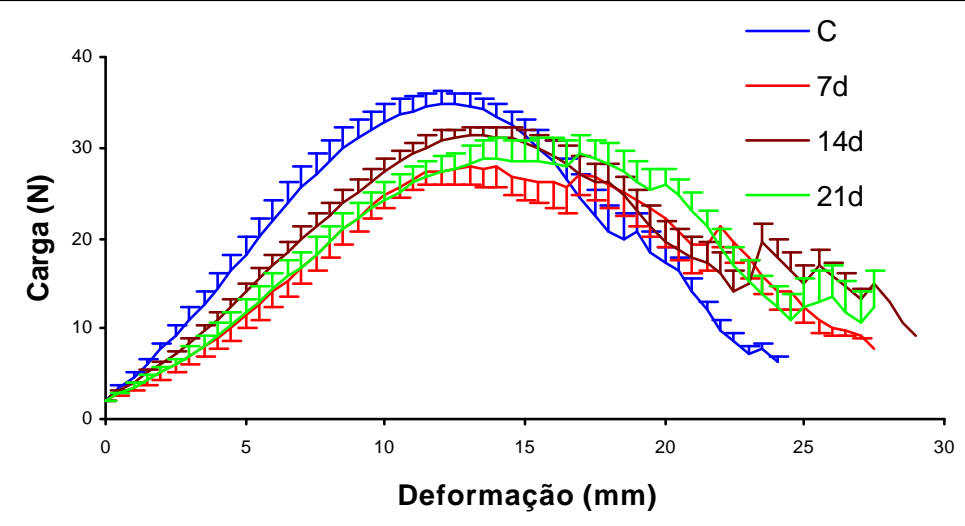

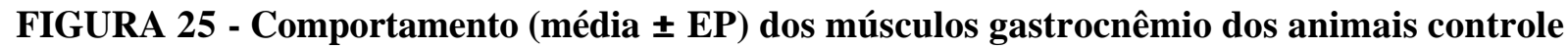
(C) e dos suspensos pelos períodos de 7 (7d), 14 (14d) e 21 dias (21d).

A Figura 26 apresenta o comportamento dos músculos gastrocnêmio (média $\pm \mathrm{EP}$ ) dos animais controle acompanhados dos suspensos pelos períodos de 7, 14 e 21 dias seguidos de 30 dias de natação. Pode-se constatar que as curvas dos animais tratados tendem a se aproximar do controle.

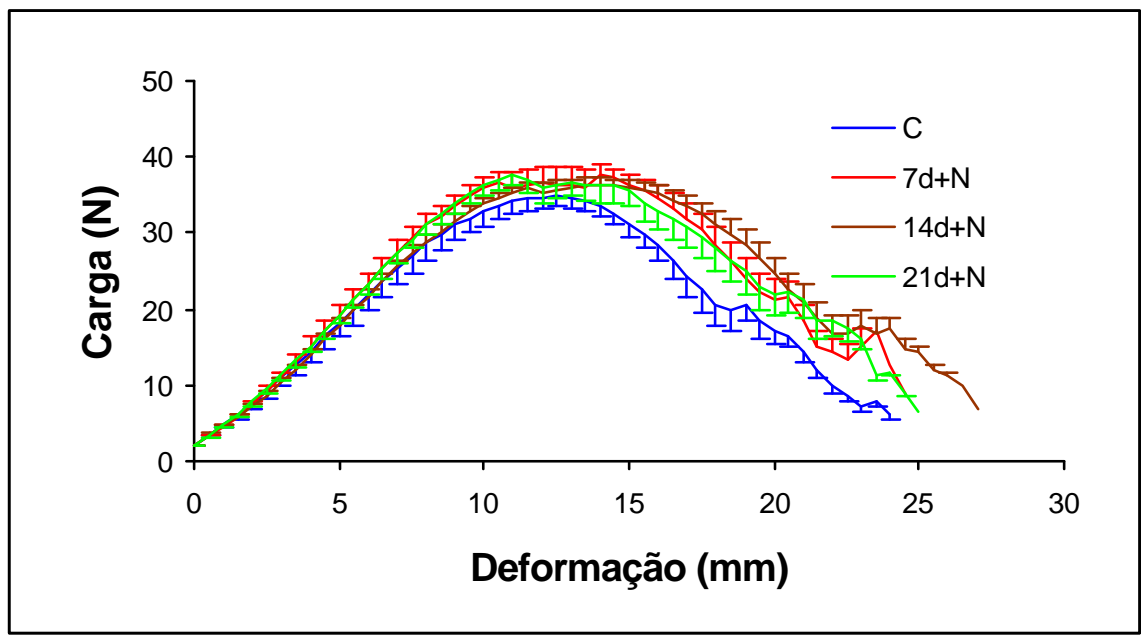

FIGURA 26 - Comportamento (média $\Perp$ EP) dos músculos gastrocnêmio dos animais controle (C) e dos suspensos pelos períodos de 7 (7d), 14 (14d) e 21 dias (21d) seguidos de 30 dias de natação. 
As Figuras 27, 28 e 29 apresentam a comparação do comportamento dos músculos gastrocnêmio dos animais controle acompanhados dos suspensos pelo mesmo período de tempo, respectivamente 7, 14 e 21 dias, submetidos ou não à natação.

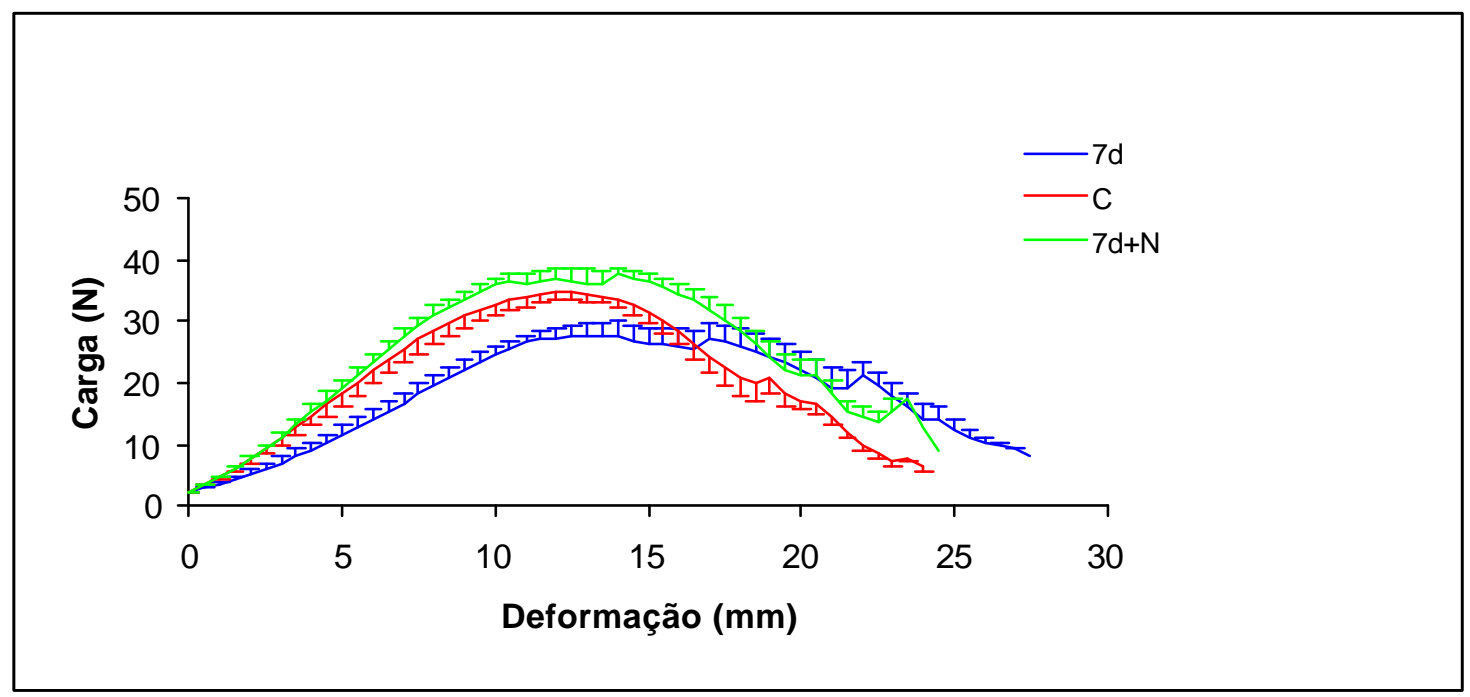

FIGURA 27 - Comparação dos ensaios mecânicos (média+ EP) dos músculos gastrocnêmios de animais controles $(\mathrm{C})$, suspensos por 7 dias (7d) e suspensos por 7 dias seguidos de natação $(7 d+N)$.

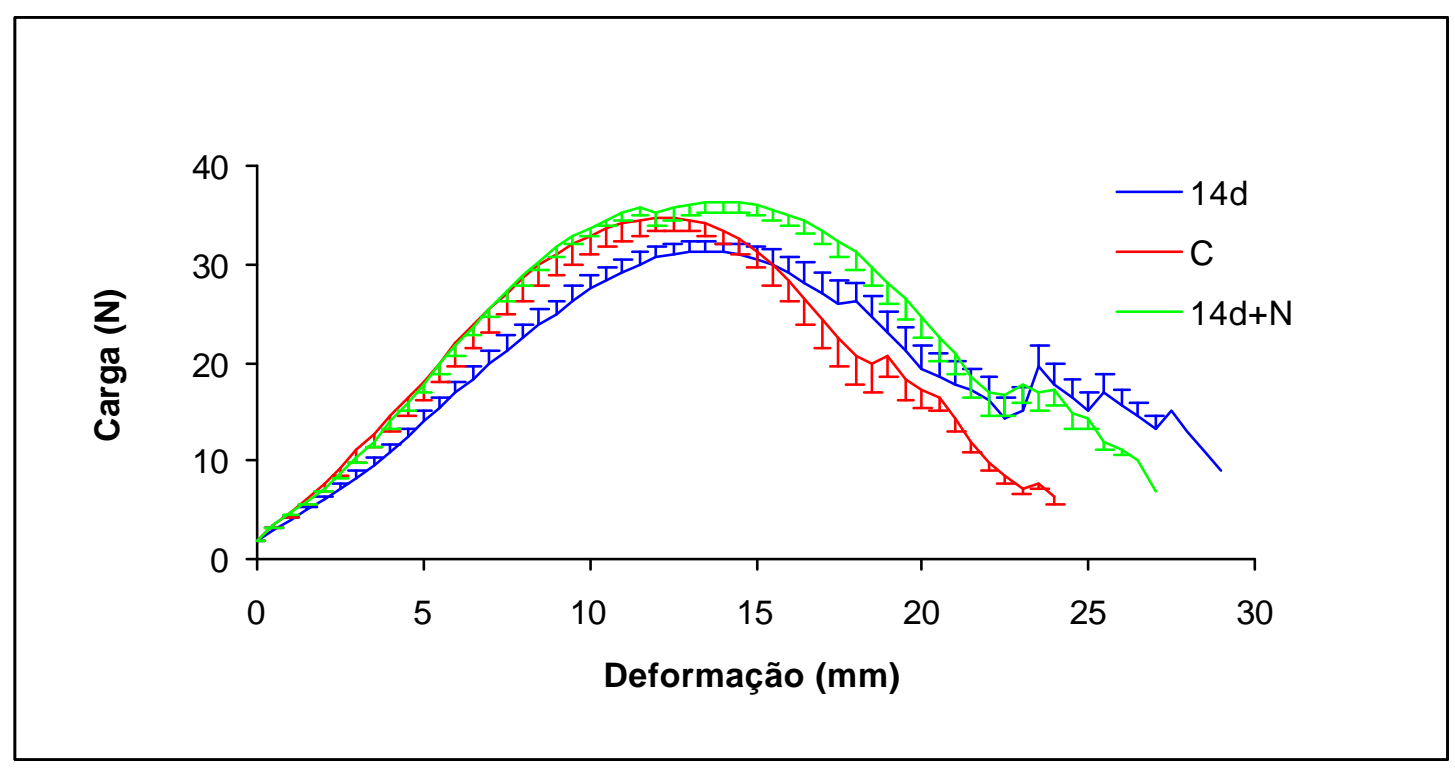

FIGURA 28 - Comparação dos ensaios mecânicos (média+ EP) dos músculos gastrocnêmios de animais controles $(C)$, suspensos por 14 dias (S14) e suspensos por 14 dias seguidos de natação $(\mathbf{S 1 4}+\mathbf{N})$ 


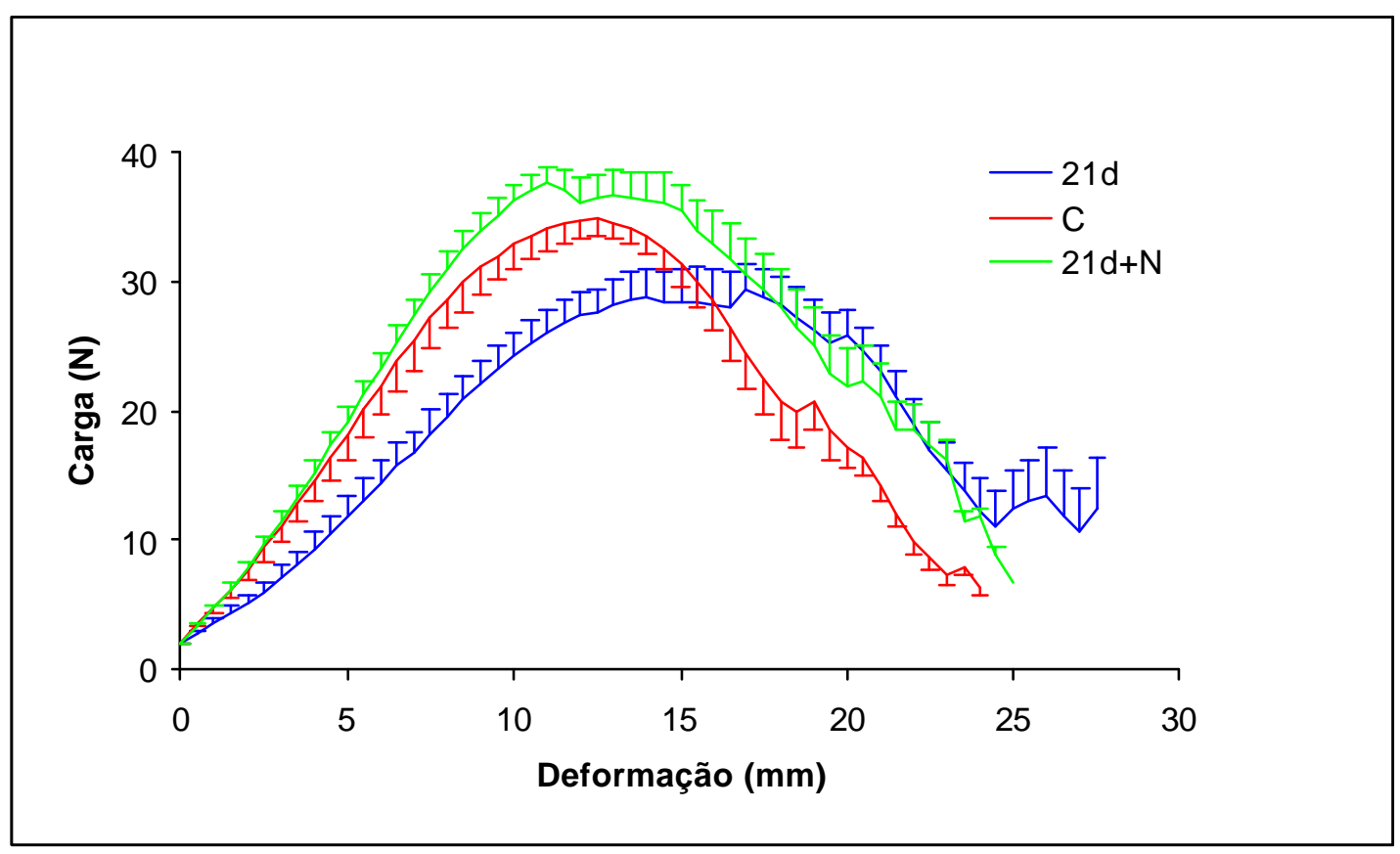

FIGURA 29 - Comparação dos ensaios mecânicos (média+ EP) dos músculos gastrocnêmios de animais controles $(C)$, suspensos por 21 dias (21d) e suspensos por 21 dias seguidos de natação $(21 d+N)$ 


\subsubsection{Limite de proporcionalidade}

A Tabela 2 apresenta os valores médios \pm desvio padrão da carga e deformação no limite de proporcionalidade dos animais submetidos aos diversos tratamentos. Os valores individuais encontram-se nos Anexos de 15 a 21.

Tabela 2 - Valores médios $\Perp$ desvio padrão de carga e deformação no limite de proporcionalidade segundo o agrupamento

\begin{tabular}{ccc}
\hline Grupo de Estudo & Carga $(\mathbf{N})$ & Deformação $\left(\mathbf{x ~ 1 0} \mathbf{~}^{-\mathbf{3}} \mathbf{m}\right)$ \\
\hline Controle & $31,6 \pm 3,7$ & $9,14 \pm 2,2$ \\
& & \\
Suspensão & & \\
7 dias & $25,5 \pm 4,2^{\mathrm{a}}$ & $9,71 \pm 2,3$ \\
14 dias & $28,5 \pm 2,9$ & $10,3 \pm 2,6$ \\
21 dias & $27,2 \pm 4,6^{\mathrm{a}}$ & $10,2 \pm 2,3$ \\
& & \\
Suspensão seguida de 30 dias de natação & & \\
7 dias & $31,4 \pm 4,3^{\mathrm{b}}$ & $8,05 \pm 1,6^{\mathrm{b}}$ \\
14 dias & $29,5 \pm 2,3$ & $8,09 \pm 1,1^{\mathrm{b}}$ \\
21 dias & $32,5 \pm 5,2^{\mathrm{b}}$ & $8,28 \pm 1,4^{\mathrm{b}}$ \\
\hline
\end{tabular}

${ }^{a}$ Significativamente diferente $(\mathrm{p}<0,05)$ em relação ao controle

${ }^{b}$ Significativamente diferente $(\mathrm{p}<0,05)$ em relação ao não submetido à natação

\subsubsection{Carga no limite de proporcionalidade}

$\mathrm{Na}$ análise dos valores de carga no limite de proporcionalidade foi encontrado que, nos animais submetidos à suspensão, houve significativa redução da carga quando comparada pelo teste de ANOVA com o valor controle $(\mathrm{p}=0,003)$. Aplicando-se o teste de múltiplas comparações de Tukey-Kramer pôde-se verificar que os animais suspensos por 7 e 21 dias foram os que se diferenciaram do controle. A Figura 30 apresenta os valores da carga no limite da proporcionalidade encontrados nos músculos dos animais controles e nos suspensos por 7,14 e 21 dias. 


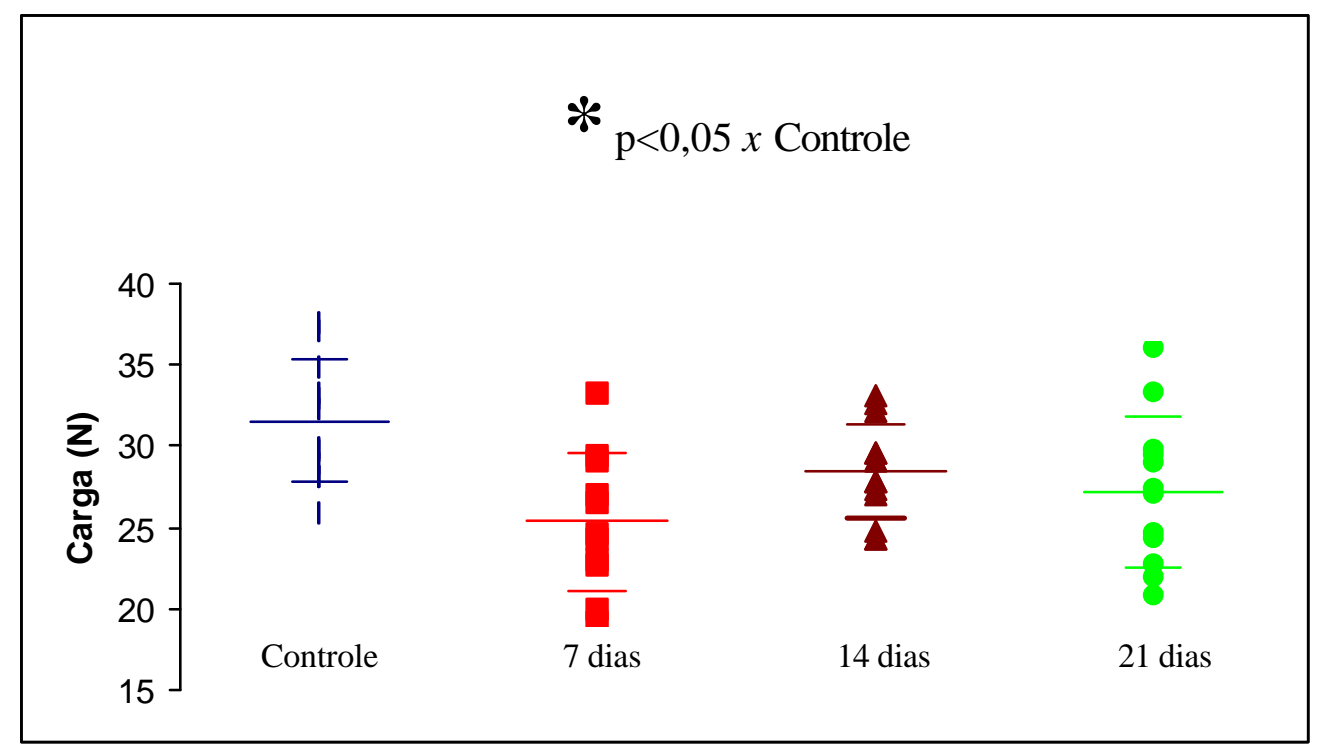

FIGURA 30 - Carga no limite da proporcionalidade do músculo gastrocnêmio de ratas controle e submetidas a 7, 14 e 21 dias de suspensão

A carga no limite de proporcionalidade nos animais submetidos à suspensão seguida de natação não diferiu do grupo controle.

Comparando-se os animais submetidos ou não à natação, porém com mesmo tempo de suspensão, a carga foi maior de maneira significativa nos animais suspensos por 7 e 21 dias e posteriormente submetidos à natação, quando comparados com os que não nadaram. Os animais suspensos por 14 dias não diferiram entre si. As Figuras 31, 32 e 33 apresentam essas comparações . 


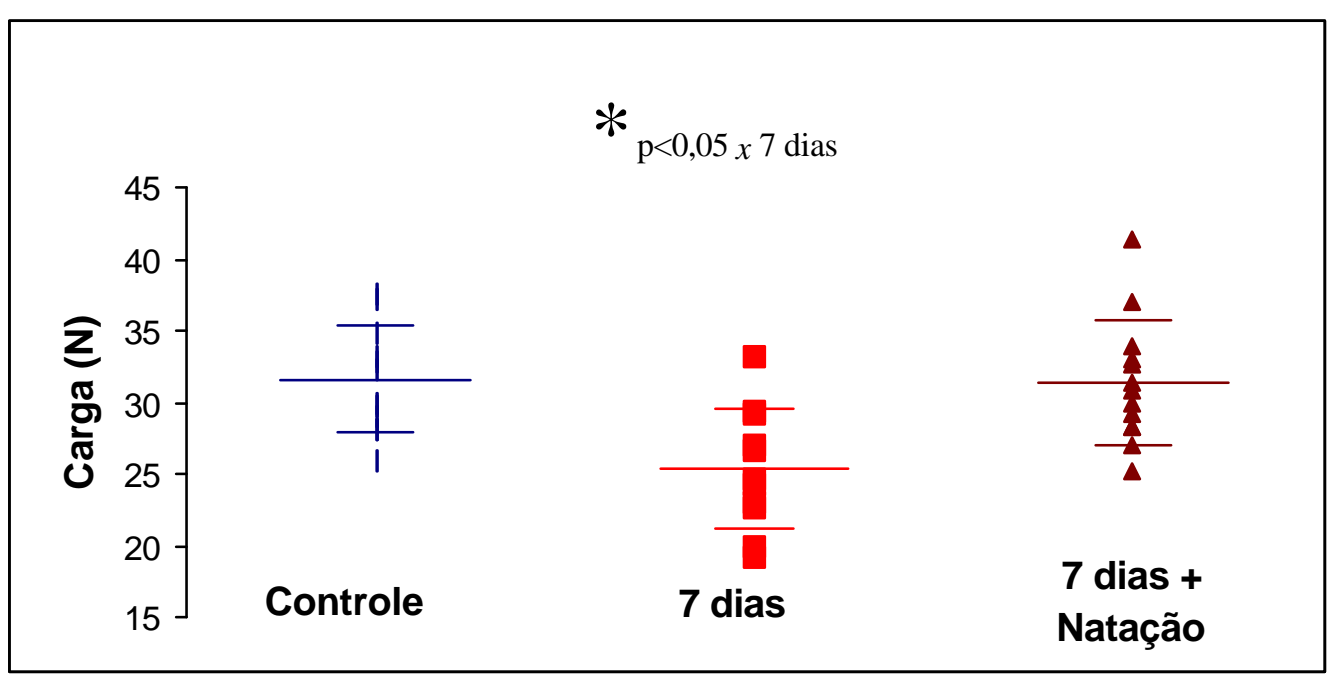

FIGURA 31 - Carga no limite da proporcionalidade do músculo gastrocnêmio de ratas controle e ratas submetidas à suspensão por 7 dias seguidos ou não de natação.

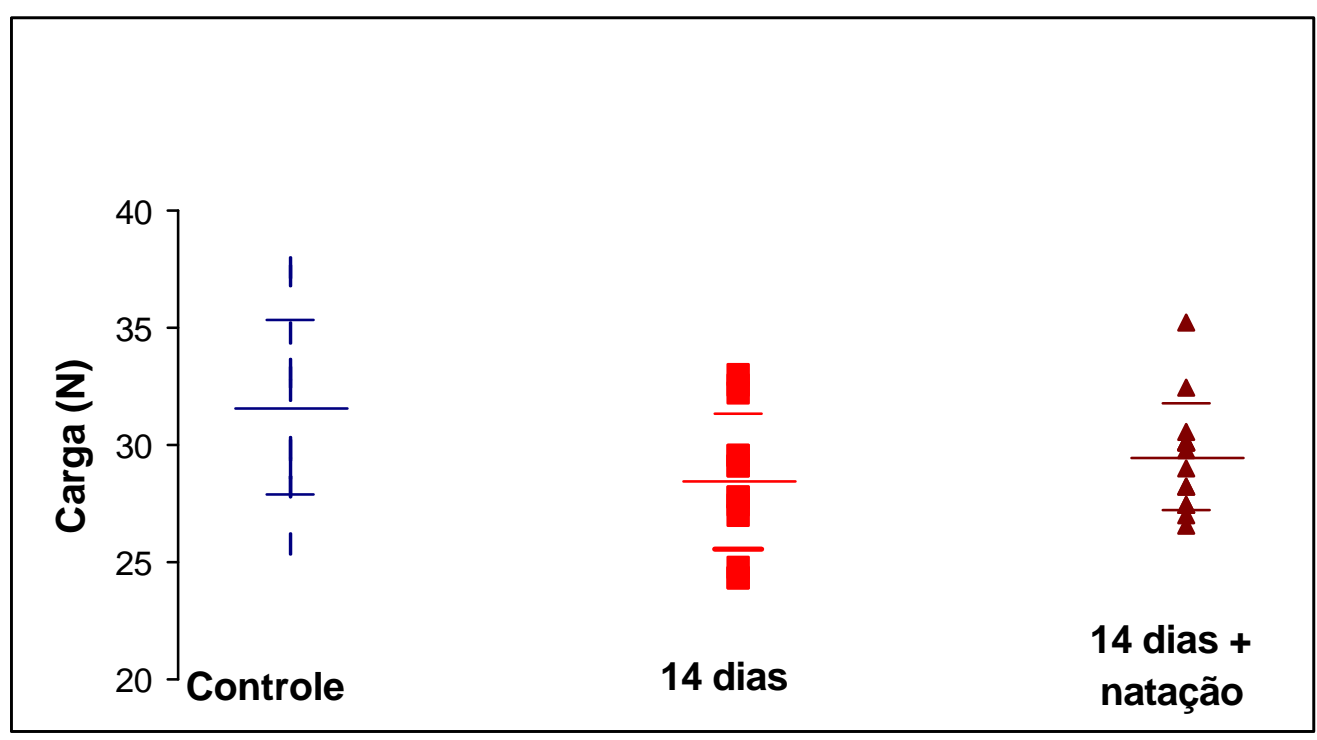

FIGURA 32 - Carga no limite da proporcionalidade do músculo gastrocnêmio de ratas controle e ratas submetidas à suspensão por 14 dias seguidos ou não de natação. 


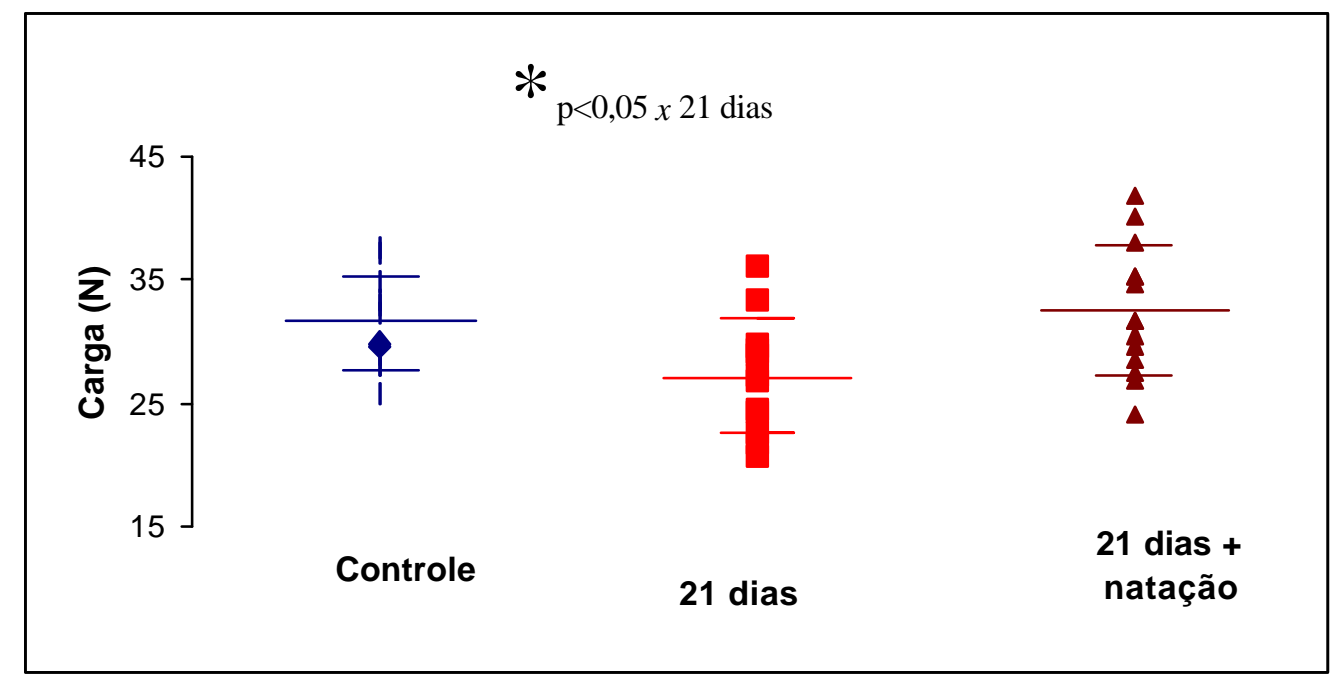

FIGURA 33 - Carga no limite da proporcionalidade do músculo gastrocnêmio de ratas controle e ratas submetidas à suspensão por 21 dias seguidos ou não de natação.

\subsubsection{Deformação no limite de proporcionalidade}

Os valores da deformação no limite de proporcionalidade dos animais submetidos ou não a natação, quando comparados com o grupo controle, não apresentaram diferença estatisticamente significante.

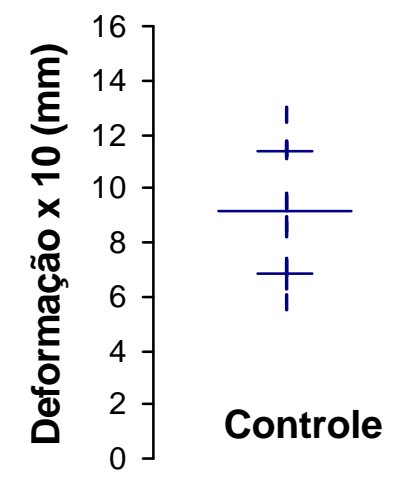

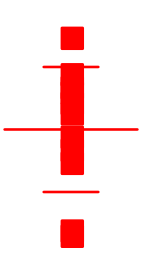

7 dias

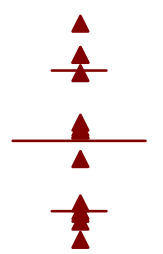

14 dias

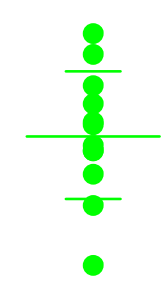

21 dias

FIGURA 34 - Deformação no limite da proporcionalidade do músculo gastrocnêmio de ratas submetidas a diferentes períodos de suspensão. (Não há diferença estatística quando cada grupo é comparado com o controle). 
Comparando-se os grupos suspensos pelo mesmo tempo e submetidos ou não à natação, registrou-se menor deformação no limite de proporcionalidade nos animais submetidos à natação. Para os animais suspensos por 7 dias a significância estatística foi limítrofe com $\mathrm{p}=0,049$, por 14 dias $\mathrm{p}=0,006$ e por 21 dias $\mathrm{p}=0,015$. As Figuras 35, 36 e 37 apresentam essas relações.

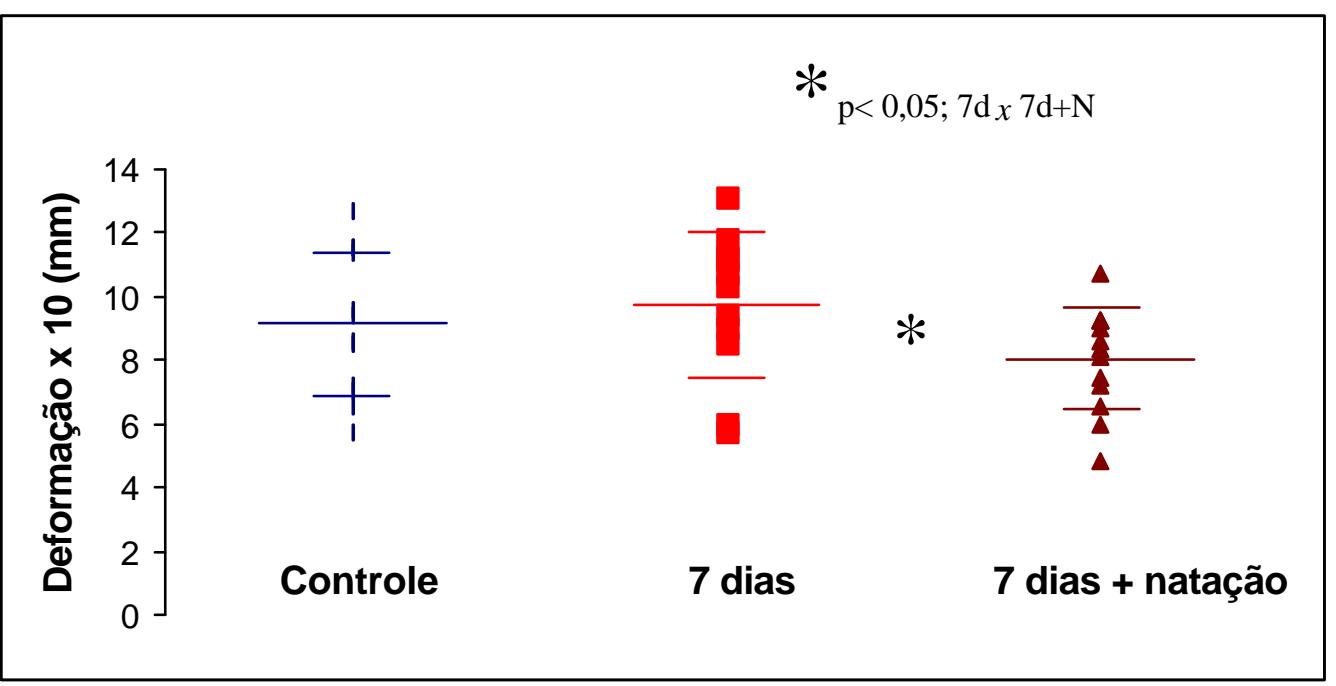

FIGURA 35 - Deformação no limite da proporcionalidade do músculo gastrocnêmio de ratas controle e ratas submetidas à suspensão por 7 dias seguidos ou não de natação.

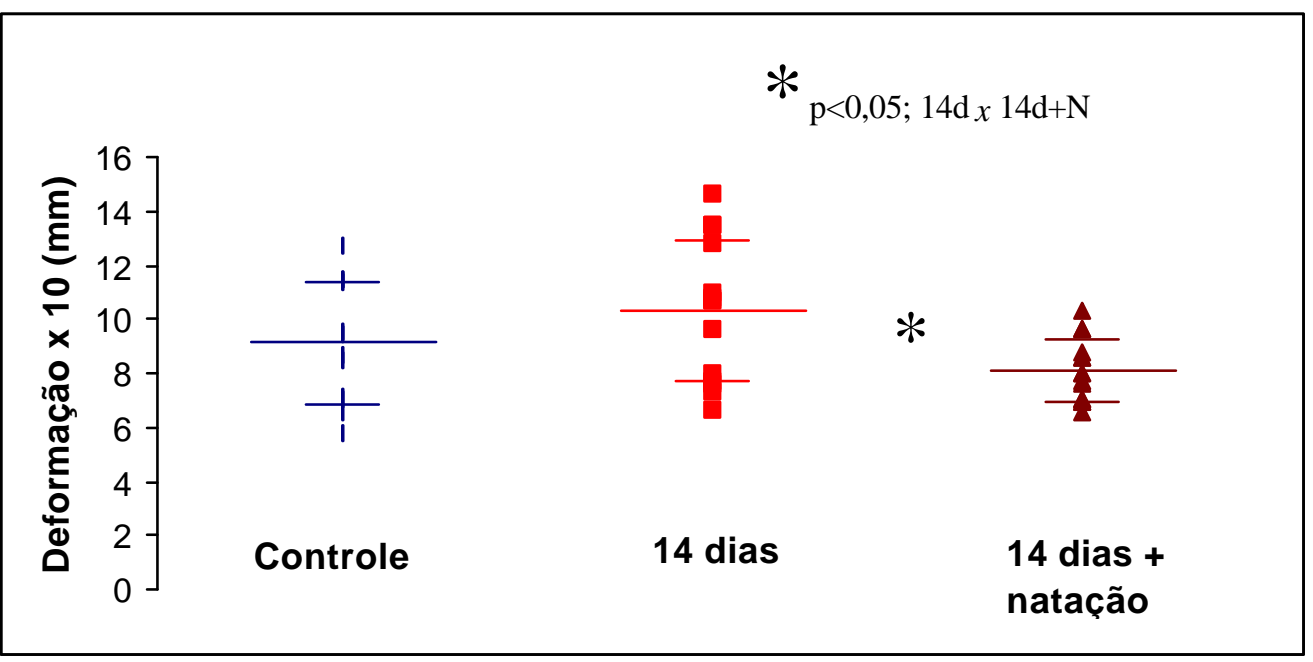

FIGURA 36 - Deformação no limite da proporcionalidade do músculo gastrocnêmio de ratas controle e ratas submetidas à suspensão por 14 dias seguidos ou não de natação. 


$$
*_{\mathrm{p}<0,05 ; 21 \mathrm{~d} x 21 \mathrm{~d}+\mathrm{N}}
$$
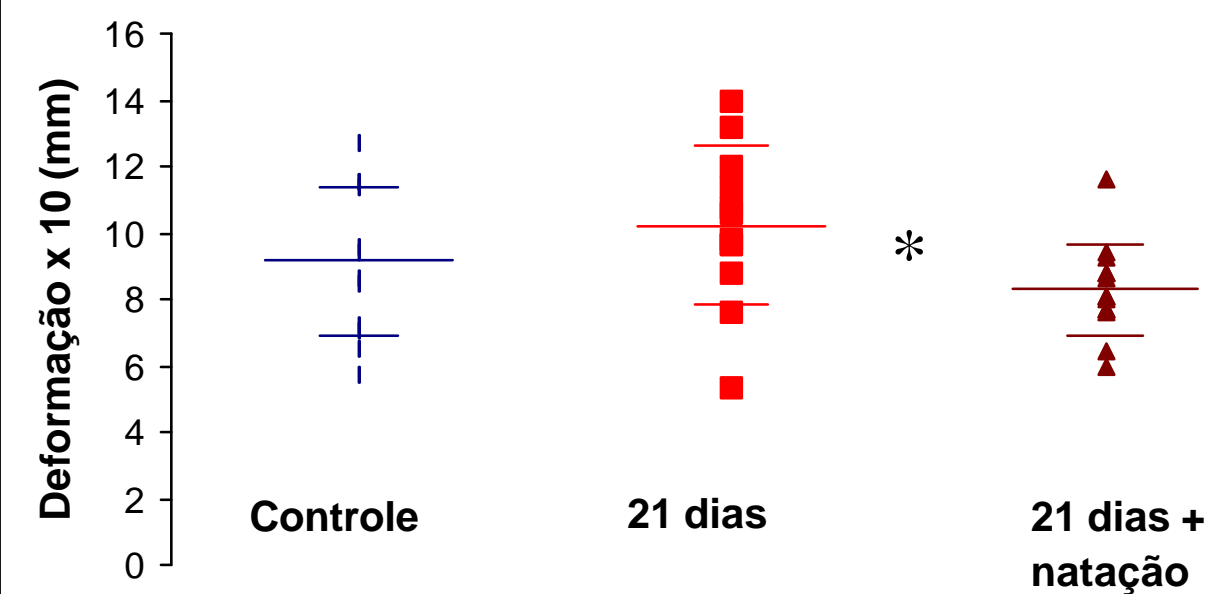

21 dias

21 dias + natação

FIGURA 37 - Deformação no limite da proporcionalidade do músculo gastrocnêmio de ratas controle e ratas submetidas à suspensão por 21 dias seguidos ou não de natação. 


\subsubsection{Limite máximo}

A Tabela 3 apresenta os valores médios \pm desvio padrão da carga e deformação no limite máximo das ratas submetidas aos diferentes tratamentos.

Tabela 3 - Valores médios \# desvio padrão de carga e deformação no limite máximo segundo o tratamento dos animais

\begin{tabular}{ccc}
\hline Grupo de Estudo & Carga (N) & Deformação $\left(\mathbf{x ~ 1 0} \mathbf{~ 1 0}^{-5} \mathbf{m}\right)$ \\
\hline Controle & $36,6 \pm 3,8$ & $12,7 \pm 2,6$ \\
& & \\
Suspensão & & \\
7 dias & $30,8 \pm 5,2^{\mathrm{a}}$ & $14,6 \pm 3,6$ \\
14 dias & $33,7 \pm 2,3$ & $14,8 \pm 3,1$ \\
21 dias & $32,7 \pm 3,9$ & $14,8 \pm 4,1$
\end{tabular}

Suspensão seguida de 30 dias de natação

$\begin{array}{ccc}7 \text { dias } & 38,6 \pm 4,4^{\mathrm{b}} & 12,7 \pm 2,1 \\ 14 \text { dias } & 37,1 \pm 3,2^{\mathrm{b}} & 13,5 \pm 1,5 \\ 21 \text { dias } & 39,3 \pm 5,3^{\mathrm{b}} & 13,2 \pm 1,9\end{array}$

${ }^{\mathrm{a}}$ Significativamente menor $(\mathrm{p}<0,05)$ quando comparado com controle.

${ }^{\mathrm{b}}$ Significativamente maior $(\mathrm{p}<0,05)$ quando comparado ao não submetido à natação .

\subsubsection{Carga no limite máximo}

Comparando-se os animais que foram suspensos e não submetidos à natação com os controle, pode-se verificar que os grupos são diferentes (ANOVA, p=0,007). Pelo teste de múltiplas comparações de Tukey-Kramer verifica-se que os animais suspensos por 7 dias apresentam carga no limite máximo inferior ao controle $(p<0,001)$. Esses valores estão representados na Figura 38. 


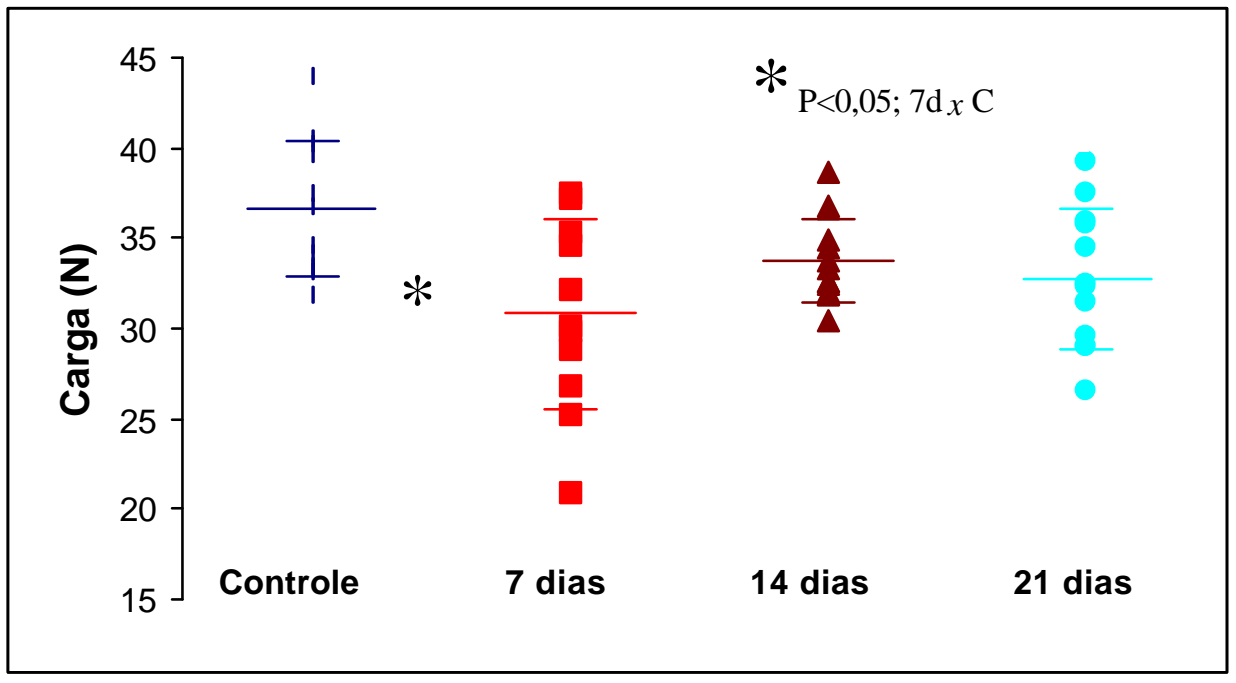

FIGURA 38 Carga no limite máximo de músculo gastrocnêmio de ratas submetidas a diferentes períodos de suspensão, em relação ao controle.

Quanto aos ratos submetidos à natação não se detectou diferença, quando comparados com o grupo controle.

Comparando-se os animais que nadaram ou não e suspensos pelo mesmo período notase que os animais submetidos a 30 dias de natação apresentaram valores de carga no limite máximo significativamente maiores que os animais que não nadaram. A significância estatística foi $\mathrm{p}<0,001$ para 7 dias, $\mathrm{p}=0,003$ para 14 dias e $\mathrm{p}=0,002$ para 21 dias. As Figuras 39, 40 e 41, respectivamente, apresentam esses valores.

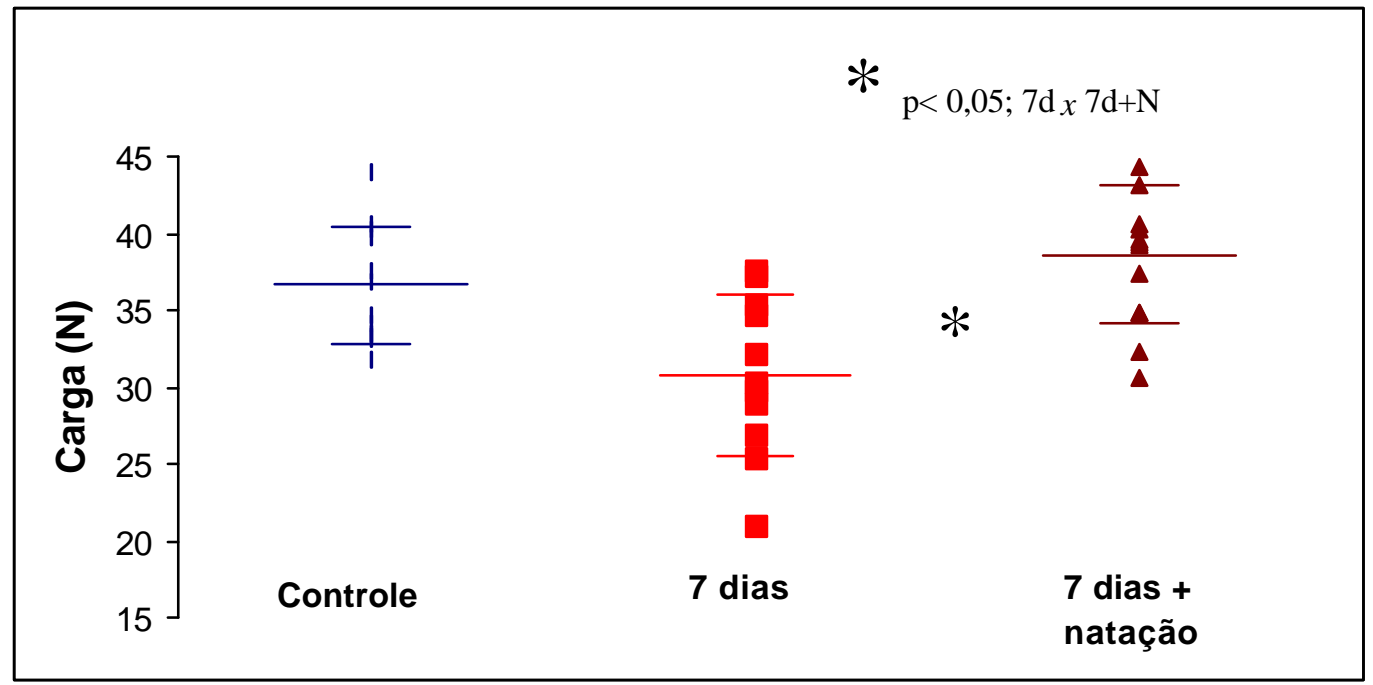

FIGURA 39 - Carga no limite máximo do músculo gastrocnêmio de ratas submetidas à suspensão por 7 dias seguidos ou não de natação. 


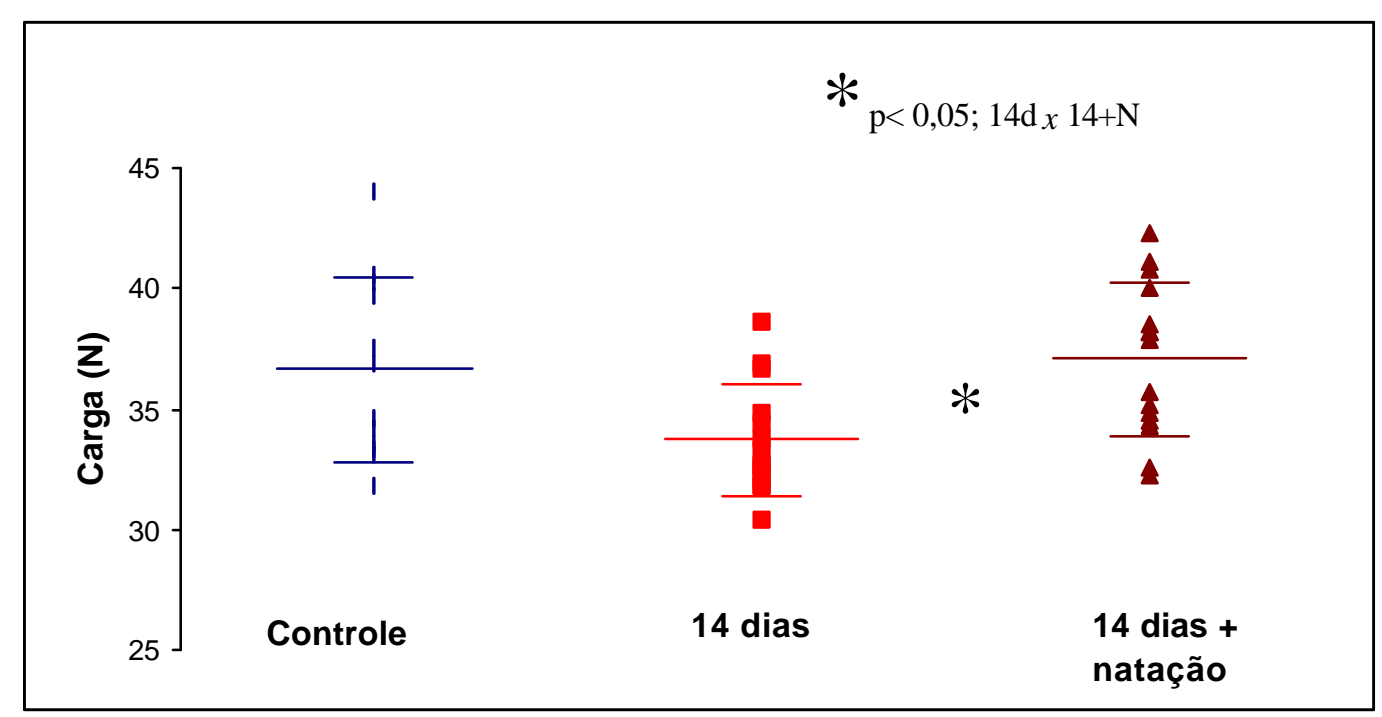

FIGURA 40 - Carga no limite máximo do músculo gastrocnêmio de ratas submetidas a suspensão por 14 dias seguidos ou não de natação.

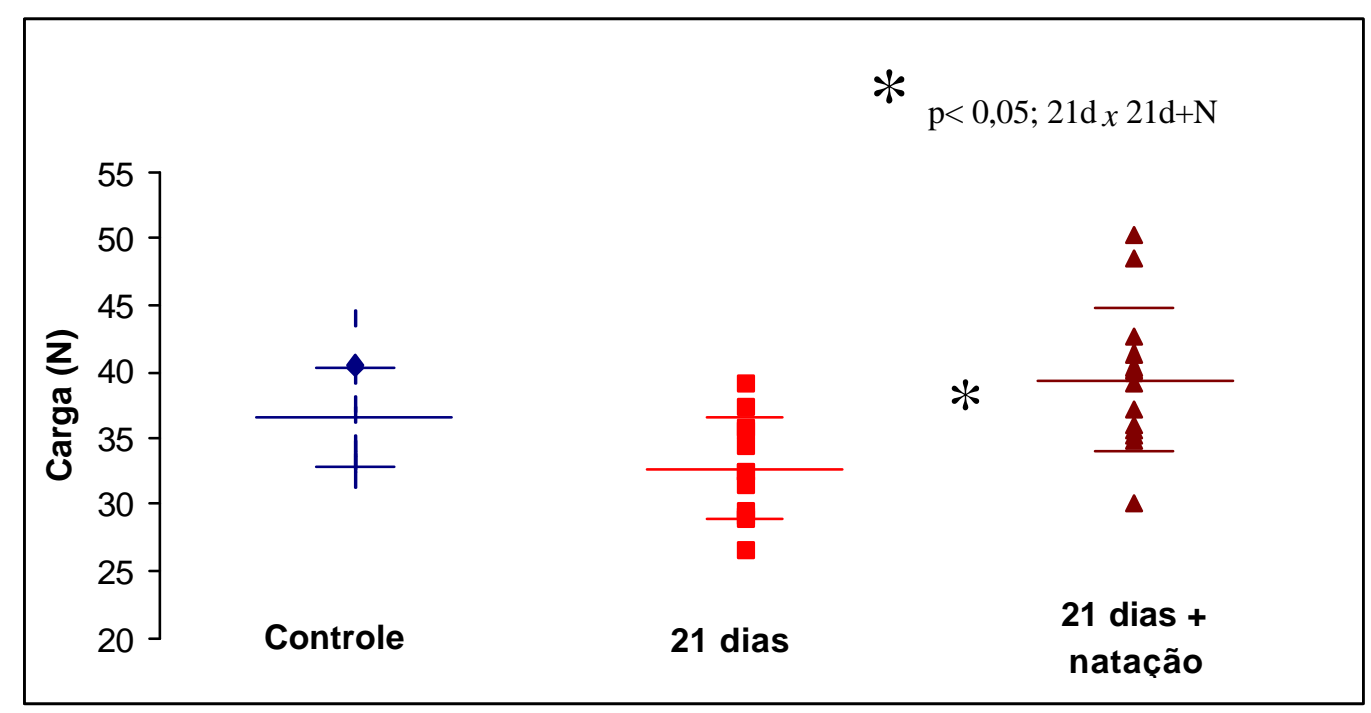

FIGURA 41 - Carga no limite máximo do músculo gastrocnêmio de ratas submetidas a suspensão por 21 dias seguidaos ou não de natação. 


\subsubsection{Deformação no limite máximo}

Comparando-se os animais suspensos e submetidos ou não à natação com o grupo controle não se pôde verificar diferenças significantes entre os grupos.

Na comparação dos animais suspensos pelo mesmo período e submetidos ou não à natação pode-se verificar que as diferenças entre os grupos não atingiram significância estatística.

A Figura 42 apresenta os valores individuais obtidos com os músculos dos animais controles e suspensos por 7, 14 e 21 dias.

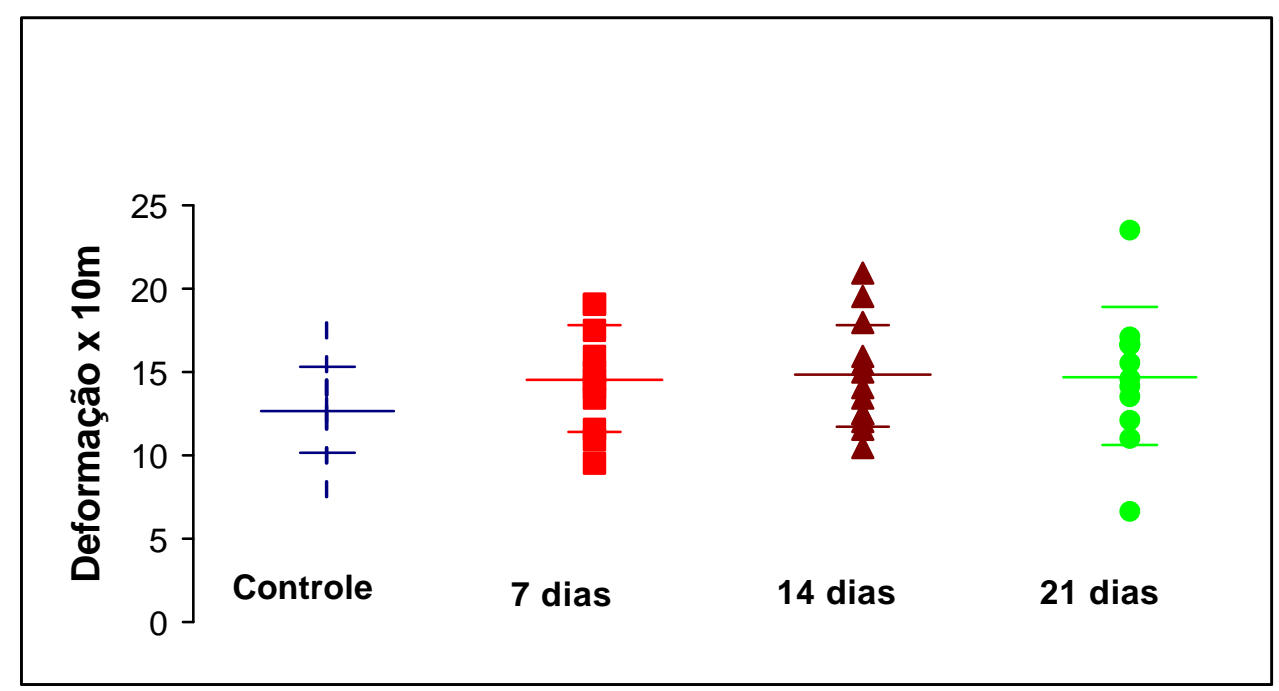

FIGURA 42 - Deformação no limite máximo do músculo gastrocnêmio de ratas submetidas a diferentes períodos de suspensão. 


\subsubsection{Rigidez}

Como verificado na Tabela 4, a rigidez do músculo gastrocnêmio dos animais controle foi semelhante a dos suspensos não submetidos à natação. No entanto, a comparação dos animais controle com os submetidos à natação mostrou que a diferença entre os grupos atingiu o limite da significância estatística $(\mathrm{p}=0,054)$.

Tabela 4 - Valores médios $\#$ desvio padrão de rigidez segundo o tratamento dos animais

\begin{tabular}{cc}
\hline Grupo de Estudo & Rigidez $\left(\mathbf{1 0}^{\mathbf{3}} \mathbf{~ N} / \mathbf{m}\right)$ \\
\hline Controle & $3490 \pm 993$ \\
& \\
Suspensão & \\
7 dias & $3186 \pm 740$ \\
14 dias & $3093 \pm 694$ \\
21 dias & $3343 \pm 785$
\end{tabular}

Suspensão seguida de 30 dias de natação

7 dias

$4266 \pm 787^{\mathrm{a}}$

14 dias

$3929 \pm 439^{\mathrm{a}}$

21 dias

$4085 \pm 563^{\text {a }}$

${ }^{\mathrm{a}}$ Significativamente maior $(\mathrm{p}=0,05)$ que os animais não submetidos à natação.

Comparando-se os animais suspensos pelo mesmo período e submetidos ou não à natação observa-se que, para todos os períodos de suspensão, os gastrocnêmios dos animais submetidos à natação apresentaram rigidez estatisticamente maior que os não exercitados. A significância estatística foi respectivamente $\mathrm{p}=0,002$ para os suspensos por 7 dias, $\mathrm{p}<0,001$ para 14 dias e p=0,01 para 21 dias de suspensão. As Figuras 43, 44 e 45 apresentam esses valores. 


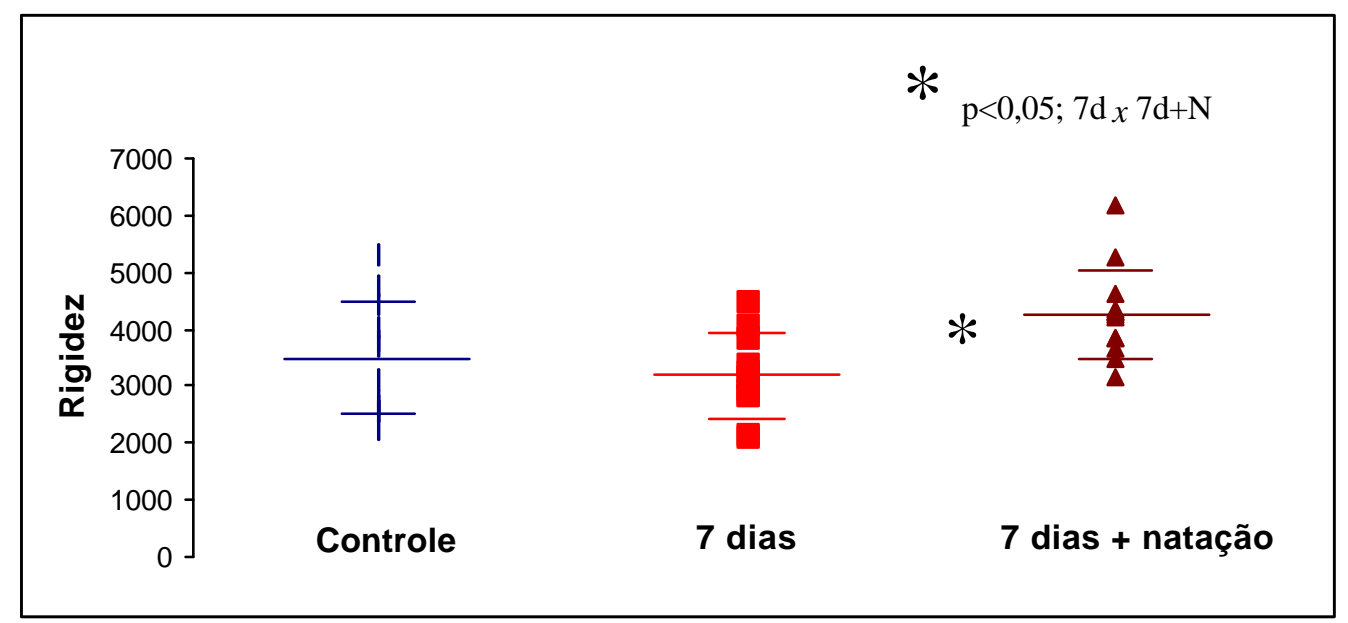

FIGURA 43 - Rigidez do músculo gastrocnêmio de ratas submetidas à suspensão por 7 dias seguidos ou não de natação.

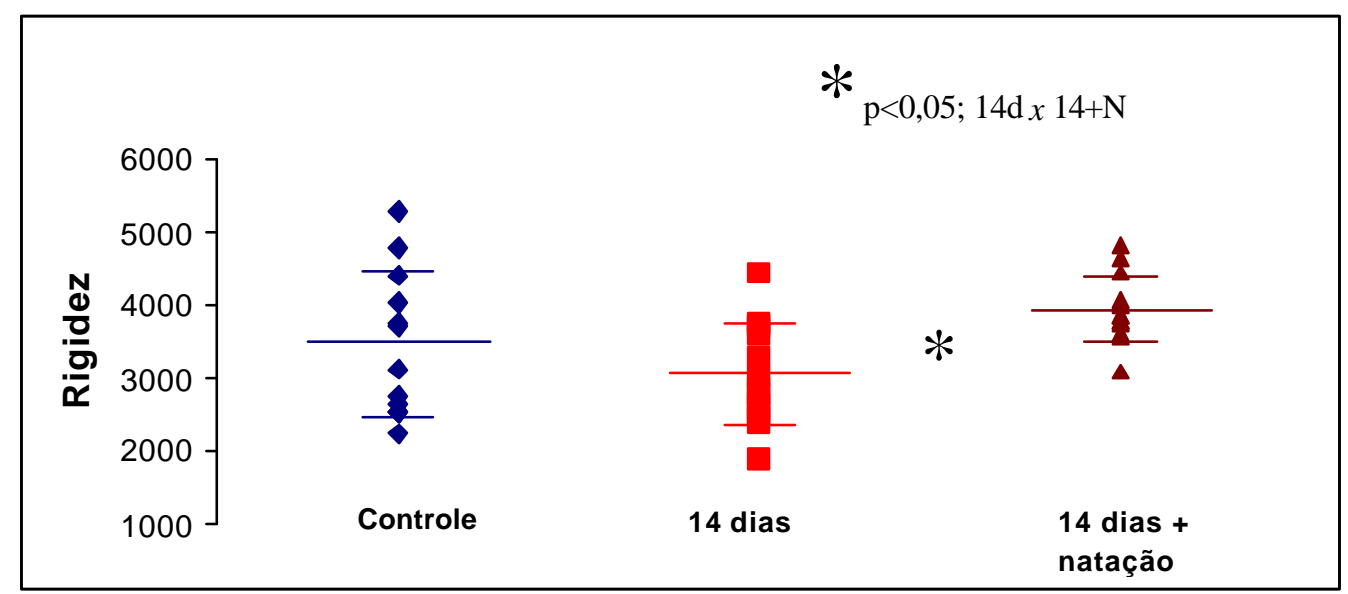

FIGURA 44 - Rigidez do músculo gastrocnêmio de ratas submetidas à suspensão por 14 dias seguidos ou não de natação. 


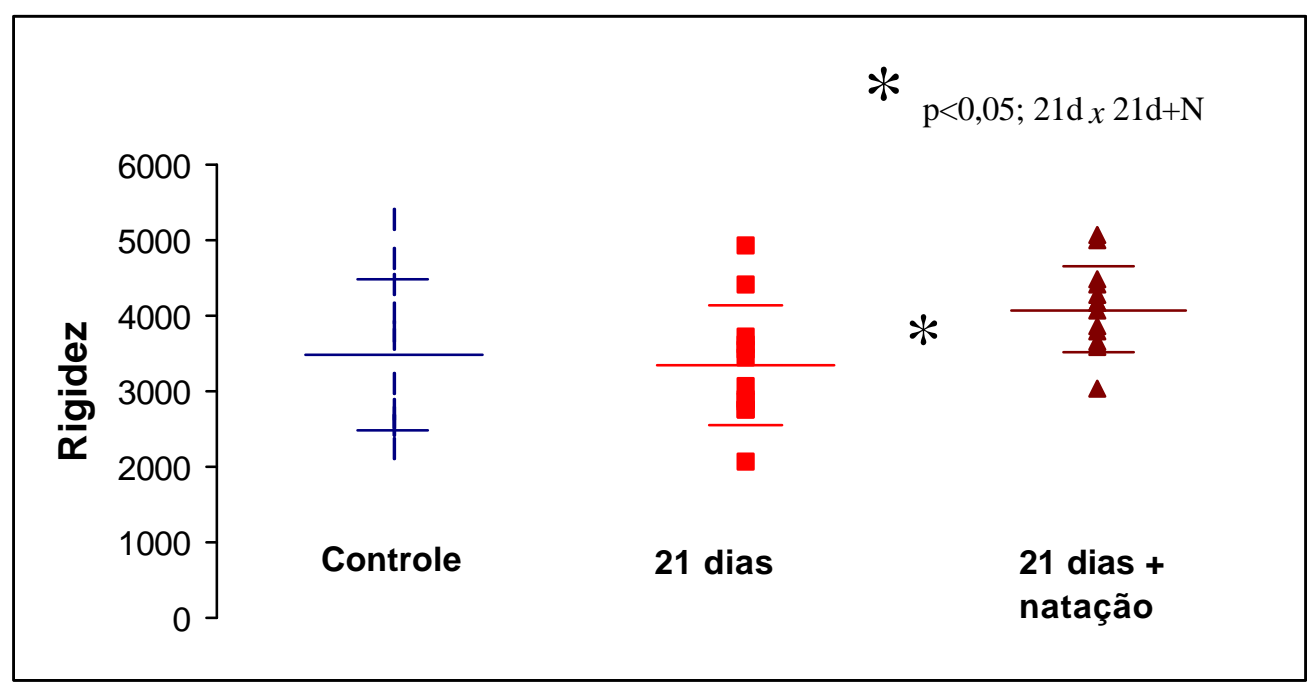

FIGURA 45 - Rigidez do músculo gastrocnêmio de ratas submetidas à suspensão por 21 dias seguidos ou não de natação. 


\section{DISCUSSÃO}

O grande interesse despertado pelos efeitos da hipoatividade no corpo humano refletiu- se na maior quantidade de conhecimento produzido visando a melhor compreender como os vôos espaciais afetam o organismo. Esses resultados, gerados a partir de dados obtidos durante os vôos e em modelos experimentais, principalmente a partir de estudos animais, estão provendo informações que trarão melhor entendimento da função muscular, no espaço e na terra. Além disso, os estudos poderão oferecer evidências importantes de como programar procedimentos corretivos apropriados, seja em termos de dietas, seja em termos de exercícios, visando a garantir a manutenção da saúde do astronauta.

Muitos investigadores, para produzirem atrofia por desuso ou não neurogênica, utilizam como modelo experimental a imobilidade por meio do engessamento bilateral dos membros posteriores de animais (HOLLOSZY e BOOTH, 1976; BOOTH e SEIDER, 1979; CARVALHO, 2001; FRATESCHI, 2002) ou por sistema de fixação rígida das articulações por pinos (FISHBACK e ROBBINS, 1969, MAX, 1972). Esses métodos são apropriados para a investigação inicial das bases fisiológicas da profunda adaptação muscular que ocorre no paciente ortopédico imobilizado. No entanto, eles não fornecem informações que possam descrever os mecanismos da adaptação fisiológica dos pacientes cujo nível de mobilidade ou de aplicação do peso foram menos comprometidos.

Modelos animais de hipoatividade como suspensão dos membros posteriores são importantes nos estudos das atrofias por desuso, já que permitem movimentos, porém sem a ação do peso ou impulsos contra resistência. Um grande número de sistemas de suspensão foi desenvolvido visando a simular um ambiente de decréscimo de gravidade (MUSACCHIA et al., 1980; MOREY-HOLTON e WRONSKI, 1981; KASPER; WHITE; MAXWELL, 1990). 
Existem dois sistemas mais comumente utilizados; a) O sistema de suspensão do corpo com o emprego de arreios e b) o sistema de suspensão pelo cauda. O sistema de suspensão com arreio eleva o animal apoiando-o num suporte de tecido que envolve o corpo e permite a saída da cabeça e membros por orifícios. (MUSACCHIA et al. 1980; KASPER; WHITE; MAXWELL, 1990). Este sistema é preso a uma placa de alumínio que permanece no dorso do animal. Esta unidade é conectada a um sistema de roldanas que permite que o animal use seus membros anteriores para se mover pela gaiola. No entanto, o dorso e a amplitude de movimentação dos membros ficam restritos.

Um sistema ideal de impedimento da mobilidade física deveria mimetizar a restrição ao leito, diminuir a pressão do peso e permitir a movimentação relativamente irrestrita do dorso e dos membros. Para atingir esses objetivos, Kasper et al.(1993) modificaram o sistema de suspensão dos membros posteriores desenvolvido por Morey para promover atrofia muscular. Esse método foi escolhido para realizar o presente estudo devido a sua capacidade em simular as principais características da imobilização física que são: a) falta de apoio, porém com movimentos livres dos membros posteriores; b) capacidade de manter hábitos como comer, beber e c) capacidade de se movimentar por todo o ambiente.

Modelos de suspensão como o utilizado no presente estudo são importantes para o estudo da atrofia de desuso, já que eles se aproximam da limitação de movimentos que sofrem pessoas restritas à cama ou com as atividades limitadas (MUSACCHIA et al. 1980; MOREYHOLTON e WRONSKI, 1981; FITTS et al. 1986). Mais importante, ainda, foi utilizar um modelo que, apesar de desenvolver atrofia, manteve os animais em condições sadias, o que permitiu a realização de exercícios para a recuperação. Outros métodos de imobilização ou suspensão dos membros traseiros causam lesões secundárias como as decorrentes da retirada cirúrgica dos pinos (JASPER e TISCHLER, 1984), anéis (MOREY-HOLTON e WRONSKI, 
1981), úlceras de decúbito nas áreas de engessamento ou em outras regiões, (MUSACCHIA; STEFFAN; DEAVERS, 1981) .

No presente estudo, a fim de que se pudesse fazer as avaliações propostas, foram constituídos 7 grupos de animais; o grupo controle, 3 grupos submetidos à suspensão por 7 , 14 e 21 dias e outros 3 grupos de ratas, também submetidos à suspensão por 7, 14 e 21 dias, porém seguidos de período de natação de 30 dias.

O primeiro problema prático na constituição desses grupos foi garantir certa uniformidade do tamanho dos ratos, já que houve variação no período de observação dos animais, que variou de 1 dia no grupo controle a 51 dias no grupo suspenso por 21 dias seguidos de 30 dias de natação. Para minimizar a diferença de tamanho decorrente do período de observação cuidou-se para que os animais avaliados fossem adulto-jovens. Desta forma, foi planejado que os 91 animais estudados possuíssem peso inicial dentro do previsto, ou seja, entre 200 e $300 \mathrm{~g}$ como pode ser verificado na Tabela 1.

A evolução do peso dos animais durante a suspensão teve um comportamento peculiar. Após 7 e 14 dias de suspensão os animais apresentaram perda de peso estatisticamente significativa. No entanto, após 21 dias de suspensão a queda do peso não foi relevante.

Pode-se aventar algumas possibilidades para explicar a perda de peso dos animais, uma delas seria que a perda de peso foi decorrente de atrofia muscular (FITTS; RILLEY; WIDRICK, 2000). Está bem demonstrado que a suspensão dos animais retirando o peso dos membros causa atrofia, diminuição da capacidade funcional, e aumento da fadiga dos músculos dos membros, com a maior alteração observada nos músculos antigravitacionais como o sóleo (RILEY et al., 1987; CAIOZZO et al.,1994; WIDRICK et al., 1999). Atrofia suficiente para causar perda de peso só é verificada depois de semanas. O engessamento do tornozelo em flexão dorsal causou o alongamento transitório do gastrocnêmio, porém sem 
diferença no peso comparado ao controle após 8 dias; subseqüentemente o peso diminuiu de forma exponencial. Engessamento do tornozelo em flexão plantar causou atrofia após 3 dias. Outros estudos usando pinos nos tornozelos ou nos joelhos para imobilizar as patas posteriores em posição perto daquela de repouso causaram atrofia no gastrocnêmio de cobaias após 4 semanas (MAIER et al., 1976) e após 6 meses em primatas (EDGERTON et al., 1975). No entanto, esses estudos referem se à perda de peso do músculo avaliado e não do animal como um todo. Em nosso modelo não pesamos o músculo porque ele não ficava isolado, mas sim preso aos côndilos femorais e a pata.

Outra possibilidade a se ponderar é que a perda de peso apresentada foi decorrente de adaptação das ratas ao sistema de suspensão. O sistema utilizado permite ampla movimentação do animal pela gaiola, mantendo seus hábitos básicos de alimentação e exploração noturnos. Ao se retirar a suspensão não houve evidência de lesão da pele, que poderia trazer desconforto aos animais. Kasper et al., (1993) relataram que, após 28 dias de suspensão em sistema semelhante ao empregado no presente estudo, os animais estavam $16 \%$ menos pesados que os controles. Os autores justificam a perda de peso como adaptação dos animais. A perda apresentada pelos animais do presente estudo, apesar de significativa, foi de apenas $5 \%$ aos 7 dias e $4 \%$ aos 14 dias. O que se depreende da literatura é que a perda de peso detectada nos animais do presente estudo, provavelmente, foi devida à adaptação ao sistema de suspensão utilizado.

Para se avaliar o grau de comprometimento muscular foi utilizado o ensaio de tração, em que foram obtidas cinco propriedades mecânicas: carga e deformação no limite da proporcionalidade, carga e deformação máxima, e rigidez, que foram comparadas entre os diferentes grupos submetidos à suspensão e um grupo controle.

Um dado metodológico que merece destaque é que, no presente estudo, optamos por avaliar somente os músculos cuja ruptura se deu no ventre múscular. Järvinen (1976) relatou, 
em estudo de tração do gastrocnêmio, que a ruptura ocorreu no ventre muscular em $94 \%$ dos seus casos. Da mesma forma, no presente estudo, houve poucas rupturas nos pontos de inserção óssea. Pela eventualidade do ocorrido e possibilidade de que a ruptura fora do ventre muscular possa estar ocorrendo por problemas técnicos, optamos por não analisar esses casos. Essa é uma explicação para o número variável de animais entre os grupos estudados.

A carga necessária para atingir o limite da proporcionalidade do músculo gastrocnêmio foi menor nos animais suspensos por 7 e 21 dias, quando comparados com os controles. No entanto, após 14 dias de suspensão não se detectou diferença alguma. A deformação apresentada pelo músculo com a aplicação dessa carga não diferiu do grupo controle. A carga necessária para atingir o limite máximo foi menor aos 7 dias quando comparado com o controle, porém aos 14 e 21 dias não se encontrou diferença. A deformação detectada à aplicação da carga máxima foi semelhante no músculo dos animais submetidos à suspensão e dos controles. A rigidez calculada para os gastrocnêmios dos animais controle foi semelhante a dos animais suspensos. Esses dados nos oferecem indicação de que a alteração apresentada pelo músculo gastrocnêmio após a suspensão não foi muito grande, já que não apresentou um padrão de piora gradual do desempenho muscular diretamente proporcional ao tempo de suspensão.

Esses resultados podem ser justificados pelas informações disponíveis na literatura.

O impedimento da mobilidade pode alterar de maneira diferente os diversos tipos musculares. A maioria dos músculos dos mamíferos pode ser caracterizada como músculos de ação rápida ou lenta. A diferença entre as velocidades de contração é função da especificidade da população de fibras que o músculo é composto. Cada fibra muscular esquelética (tipo I, tipo IIa e tipo IIb) tem propriedades bioquímicas e fisiológicas peculiares e, portanto, reagem diferentemente às agressões (CLOSE, 1967; BROOKE e KAISER, 1970). 
Músculos de contração rápida ou lenta são desenhados para diferentes funções. Os músculos lentos são para o suporte postural e suporte do peso, enquanto que os músculos rápidos são para a movimentação rápida e mais precisa. Músculos com predominância de fibras de contratilidade lenta (tipo I), como o sóleo atrofiam mais intensamente que os músculos com fibras de contração rápida (tipo II), quando submetidos à ausência da ação do peso (KASPER et al.,1993).

O músculo utilizado neste estudo foi o gastrocnêmio, em face de sua localização e função, além de apresentar a vantagem de poder ser avaliado por testes de tração, pois preservando- se as origens e inserção ósseas, fica facilitada a fixação à maquina para a realização do ensaio.

Geralmente, em muitos esportes, esse músculo trabalha sob condições de atividade física extrema, tendo risco aumentado para lesões e rupturas e o tratamento requer períodos variáveis de imobilização (JÄRVINEN;VIRTANEN; EINOLA, 1992). No músculo gastrocnêmio cerca de metade de suas fibras são de características rápidas (JOHNSON et al.,1973). Dessa forma, a composição muscular mista do gastrocnêmio o torna peculiar e muito interessante de ser analisada e, provavelmente, o torna menos susceptível à atrofia causada por redução do suporte de peso. O mesmo não ocorre quando o músculo é totalmente imobilizado. Após imobilização por gesso, houve grande atrofia de todos os músculos, independente do tipo de fibras. A perda foi similar no sóleo, gastrocnêmio e plantar, com maior perda de proteína da miofibrila que do sarcoplasma (HERBISON; JAWEED; DITUNNO, 1978; CARVALHO, 2001).

Stevens; Mounier; Holly, (1993) estudaram humanos adultos antes e após 14 dias de vôo espacial e Gardetto; Schluter; Fitts, (1989) avaliaram ratos em suspensão pelos membros posteriores pelo mesmo período. Encontraram que a atrofia e perda do pico de força ativada pelo $\mathrm{Ca}^{+2}$ eram maiores nas fibras lentas tipo I do sóleo que nas fibras rápidas tipo II do 
gastrocnêmio. O vôo espacial não causou efeito no músculo extensor longo dos dedos do pé. Dados semelhantes foram encontrados por Widrick et al., (2001), cujo estudo teve o propósito de avaliar os efeitos de vôo espacial de 17 dias nas propriedades contráteis de fibras individuas rápidas e lentas isoladas do gastrocnêmio de quatro astronautas. Fibras isoladas quimicamente foram estudadas durante a contração máxima ativada pelo $\mathrm{Ca}^{+2}$ com a expressão da isoforma da cadeia pesada da miosina da fibra determinada por eletroforese em gel. Os resultados mostraram que 1) as fibras rápidas e entas do gastrocnêmio apresentaram pequena atrofia e perda de força, mas aumento de velocidade depois dos 17 dias de exposição à microgravidade 2) houve grande variação entre os quatro astronautas, que por sua vez, apresentaram grande variabilidade de atividades durante o vôo 3) a atrofia do gastrocnêmio foi muito menor que a do sóleo (WIDRICK et al., 2001).

As propriedades funcionais das fibras tipo I do gastrocnêmio foram menos afetadas durante o vôo espacial que as fibras tipo I do sóleo do mesmo astronauta (WIDRICK et al., 1999). Isto indica que a localização anatômica das células musculares e não somente a expressão da isoforma da cadeia pesada de miosina da fibra possa ser determinante importante da resposta celular durante uma viagem espacial. Consistente com os resultados desses estudos prévios, TEMPLETON et al.,a, (1984), utilizando o sistema de Morey para a simulação anti-gravitacional, não encontraram perda significante do peso seco do gastrocnêmio após duas semanas de suspensão, porém ficou evidente a diminuição do diâmetro das fibras do gastrocnêmio no exame histoquímico em alguns ratos suspensos por duas a quatro semanas (TEMPLETON et al., a ,1984)

Hoje sabe-se que a resposta atrófica ocorre de forma rápida em ambiente de microgravidade, com redução na massa do sóleo de rato em até 37\% em 4 a 7 dias (MARTIN; EDGERTON; GRINDELAND, 1988; DESPLANCHES et al., 1990; JIANG et al., 1993). Em ratos tem sido sistematicamente observado que os músculos lentos antigravitacionais 
como o sóleo e abdutor longo atrofiam mais que os músculos primariamente rápidos e os extensores são mais afetados que os flexores. Por exemplo, a fibra lenta tipo I apresenta mais atrofia induzida por vôo espacial que a fibra rápida tipo II e fibras dos músculos extensores são mais afetadas que as dos flexores, em animais. Diversos autores avaliaram, em animais, o tamanho das fibras do sóleo, gastrocnêmio medial e tibial anterior depois de 14 dias em viagem espacial (Cosmos 2044) (JIANG et al., 1992; OHIRA et al., 1992). As fibras lentas tipo I dos músculos extensores apresentaram o maior grau de atrofia, com o sóleo apresentando mais atrofia que o gastrocnêmio.

Depois de um vôo espacial de 4,5 dias (“Space Transport System-48”) o peso dos músculos sóleo, plantar e gastrocnêmio diminuíram de 38, 24 e 16\%, respectivamente, enquanto que o tibial anterior e extensor comum dos dedos não apresentaram alterações. Nesse mesmo estudo em ratos demonstrou se que a atrofia muscular foi associada a um aumento do volume de fluido intersticial (HENRIKSEN et al., 1993).

Dessa forma, na investigação, o fato do gastrocnêmio não ter sido muito afetado durante a suspensão está perfeitamente de acordo com as informações encontradas na literatura e com o fato do sistema de suspensão permitir a movimentação constante dos músculos flexores.

\section{RECUPERAÇÃO}

Além de estudar o músculo gastrocnêmio dos animais submetidos à suspensão, avaliou-se a resposta muscular após um programa de recuperação. Após o período de suspensão os animais foram submetidos a períodos de natação por uma hora, sem resistência extra, durante 30 dias.

Diversos autores ofereceram evidências convincentes que, em ratos, períodos curtos de exercícios distribuídos durante o dia são mais eficazes que um longo treino diário. Por 
exemplo, um programa de suspensão de 7 dias, intervalos de 10 minutos, 4 vezes ao dia, em que o animal ficou apoiado nos membros e andou lentamente numa esteira foi capaz de manter a massa do sóleo próxima do normal (D`AUNNO et al., 1992; WIDRICK et al.,1996; HERBERT et al.,1988). Os dados de WIDRICK et al (1996) indicam que isso é especialmente válido para pequenos períodos de suspensão de até 7 dias. Quando a suspensão foi prolongada por 14 dias, o mesmo regime de treino foi capaz de reduzir a perda muscular do sóleo em $22 \%$, e atenuou as alterações no diâmetro das fibras tipo I e a força máxima, respectivamente, em $36 \%$ e $29 \%$. Claramente, o protocolo simples e intermitente foi menos efetivo na recuperação de 14 dias que 7 dias de suspensão. Em ratos, a atrofia muscular nos primeiros 7 dias de suspensão é primordialmente causada por diminuição de síntese protéica, enquanto que a degeneração das miofibrilas não atinge seu máximo até 9 a 15 dias (THOMASON et al., 1989). Talvez o protocolo de ficar em pé intermitentemente seja mais efetivo em prevenir o declínio da síntese protéica do que em reduzir a degradação.

NORMAN et al. (2000) aplicaram, em ratos, exercícios de 60 min na esteira por 3 dias com um dia de descanso, durante o período de suspensão. Essa abordagem fez com que a massa muscular dos animais fosse significativamente maior que a dos suspensos sem treino, mas não chegou a igualar a dos controles. Esses achados são muito parecidos com outros relatos ( BALDWIN et al., 1977; KLITGAARD et al., 1988; WONG e BOOTH , 1988)

O único exercício padrão que se sabe ser capaz de induzir hipertrofia das fibras musculares é o treino com resistência de peso (FITTS; RILEY; WIDRICK, 2000). Permanecer de pé por 10 minutos com exercício de resistência intermitente (dez degraus de $15 \mathrm{~cm}$ com peso de 500g, a um degrau $/ \mathrm{min}$ ) 4 vezes ao dia, foi mais efetivo em prevenir atrofia das fibras do que somente ficar de pé (WIDRICK e FITTS, 1997).

Para proteger tanto os músculos de ação lenta como rápida, as medidas preventivas devem conter exercícios de alta resistência que utilizem contrações isoméricas e isotônicas. 
Além disso, as contrações excêntricas também se mostraram úteis para prevenir a atrofia muscular, porém aumentam a possibilidade de lesão das fibras. Assim, qualquer programa que utilize contrações excêntricas deve ser programado cuidadosamente para maximizar os efeitos anabólicos, enquanto previne a lesão das fibras (FITTS; RILEY; WIDRICK , 2000). Dessa forma, sugere-se que o "programa ideal" deva incluir contrações isométricas assim como exercícios isotônicos (concêntricos e excêntricos) e dados, tanto em ratos como em humanos, indicam os exercícios de alta intensidade como a modalidade de escolha para a proteção da estrutura muscular e função dos membros (FITTS; RILEY; WIDRICK, 2000)

Todos esses estudos apresentados visavam a desenvolver programas que prevenissem a atrofia muscular. A questão avaliada no presente estudo foi se um programa de exercícios intensos aeróbicos, quando aplicado após a ocorrência da atrofia, seria capaz de recuperar o músculo gastrocnêmio. O programa empregado nesse estudo levou a resultados bastante satisfatórios. No período de 30 dias de treinamento os animais apresentaram ganho de peso em relação ao término da suspensão. Esse fato sugere que o esforço desempenhado pelos animais não foi exagerado, pois não comprometeu seu estado geral.

Em termos da recuperação muscular, desde que não fossem grandes as alterações decorrentes da suspensão, evidentemente não era de se esperar ganhos muito significativos no desempenho muscular.

No entanto, ainda assim foram notadas diferenças significativas. A carga necessária para atingir o limite de proporcionalidade aumentou após o período de natação para todos os períodos de suspensão, atingindo significância estatística para o período de 7 e 21 dias. Devese ressaltar que foram exatamente os gastrocnêmios desses dois grupos de animais que apresentaram pior desempenho após a suspensão quando não passaram pelo período de natação. A natação tornou os músculos menos deformáveis com a carga no limite da proporcionalidade para todos períodos de suspensão. Em termos da carga necessária para 
atingir o limite máximo de deformação, os animais submetidos ao programa de natação apresentaram significativo aumento, quando comparados aos suspensos pelo mesmo período. A deformação no limite máximo não apresentou diferença entre os grupos, mas a rigidez foi maior para todos os grupos de animais submetidos à natação.

Como o desempenho aos testes de tração dos músculos gastrocnêmios dos animais submetidos ao programa de recuperação não diferiram dos animais controle, entende-se que as diferenças encontradas quando esses animais foram comparados com os animais não submetidos a treinamento são decorrentes da recuperação muscular e não de hipertrofia muscular.

A literatura apresenta alguns dados sobre a capacidade de recuperação muscular após atrofia, porém decorrentes de imobilização total que, como já demonstrado, acarreta comprometimentos muito maiores que os observados no presente estudo.

Witzman; Kim; Fitts (1982), após imobilização por 6 semanas com engessamento dos membros posteriores demonstram que, tanto os músculos de contração rápida, como os lentos conseguiram recuperar suas características contráteis. A recuperação ocorreu em períodos variáveis. Booth e Seider (1979), em seu estudo, indicam que, após a atrofia muscular obtida por 90 dias de imobilização dos membros, vários índices bioquímicos e fisiológicos podem ser recuperados. O tempo de recuperação, no entanto, varia de acordo com o índice. Assim, as concentrações de ATP, glicogênio e proteína se recuperaram em 60 dias após imobilização, enquanto que o peso e conteúdo protéico do solear já se recuperavam em 14 dias e em contraste a tensão isométrica máxima levou 120 dias para se recuperar.

A franca recuperação demonstrada em nossos animais em 30 dias, sugere, que o comprometimento muscular decorrente da suspensão seja muito menor que o devido à imobilização total por gesso. 
Finalmente, ressaltamos que a avaliação na presente investigação limita-se aos aspectos de resistência de material e estrutura. Seria interessante também estudar o músculo do ponto de vista fisológico avaliando-o, por exemplo,com o registro da contratilidade, por estimulação direta no corpo muscular ou pelo nervo. 


\section{CONCLUSÕES}

1- O sistema de suspensão utilizado não causou comprometimento físico geral importante dos animais, já que eles apresentaram discreta perda de peso e foram capazes de cumprir o programa de recuperação ulterior.

2- O sistema de suspensão utilizado foi adequado para promover a atrofia do gastrocnêmio e diminuir sua resistência mecânica.

3- O programa de recuperação por natação foi capaz de reverter as alterações mecânicas encontradas no gastrocnêmio dos animais suspensos. 


\section{REFERÊNCIAS BIBLIOGRÁFICAS}

ALLEN,D.L.; $\quad$ LINDERMAN,J.K.; $\quad$ ROY,R.R.; $\quad$ GRINDELAND， R.E.; MUKKU,V.; EDGERTON,V.R.; Growth hormone/IGF-I and/or resistive exercise maintains myonuclear number in hindlimb- unweighted muscles.; J. Appl. Physiol., v. 83, p. 1857-1861, 1997.

ALENN,D.L.; ROY,R.R.; EDGERTON,V.R.; Myonuclear domains in muscle adaptation and disease. Muscle Nerve, v. 22, p. 1350-1360, 1999.

ALLEN,D.L.;YASSUI,W.; TANAKA,T.; OHIRA,Y.; NAGAOKA,S.; SEKIGUCHI,C.; HINDS,W.E.; ROY,R.R.; EDGERTON,V.R.; Myonuclear number and myosin heavy chain expression in rat soleus single muscle fibers after spaceflight. J. Appl. Physiol., v. 81, p. 145$151,1996$.

ANDERSON,J.E.; Studies of the dynamics of skeletal muscle regeneration: the mouse came back! Biochem. Cell Biol., v. 76, p. 13-26, 1998.

BALDWIN, K.M., Examining the effects of space flight on the muscles. 2001. Disponível em: http://www.nsbri.org/humanphysiologyspace. Acesso em: 20/05/2001.

BALDWIN,K.M.; CHEADLE,W.G.; MARTINEZ,O.M.; COOKE,D.A., Effect of functional overload on enzime levels in different types of skeletal muscle. J. Appl. Physiol., v. 42, p. 312-317, 1977.

BISCHOFF; Interaction between satellite cells and skeletal muscle fibers. Development., v. 109, p. 943-952, 1990.

BOOTH, F.W.; Time course of muscular atrophy during immobilization of hindlimb in rats. J. Appl. Physiol., v. 43, p. 656- 661, 1977. 
BOOTH,F.W.; GORDON,S.E; CARLSON,C.J.; HAMILTON,M.T.; Waging war on modern chronic diseases: primary prevention through exercise biology. J. Appl. Physiol., v. 88, p. 774-787, 2000.

BOOTH,F.W.; KELSO,J.R.; Effect of hindlimb immobilization on contractile and histochemical properties of skeletal muscle. Plügers Arch., v. 342, p. 231- 238, 1973.

BOOTH,F.W.; SEIDER,M.J.; recovery of skeletal muscle after 3 months of hindlimb immobilization in rats. J. Appl. Physiol., v. 47, p. 435-439, 1979.

BROOKE, M.H.; KAYSER,K.K.; Muscle fiber types: How many and what kind?. Arch. Neurol., v. 23, p. 369-379, 1970

CAIOZZO,V.J.; BAKER,M.J.; HERRICK, R.E.; TAO,M.; BALDWIN,K.M.; Effect of spaceflight on skeletal muscle: mechanical properties and myosin isoform content of a slow muscle. J. Appl. Physiol., v. 76, p. 1764-1773, 1994.

CARVALHO, C.M.M.; Efeitos da imobilização e do exercício físico em algumas propriedades mecânicas do músculo esquelético. Dissertação de mestrado em Bioengenharia., Interunidades- Faculdade de Medicina de Ribeirão Preto/ Escola de Engenharia de São Carlos/ Instituto de Química de São Carlos, Universidade de São Paulo, Ribeirão Preto, 2001.

CHANG,Y.H.; HUANG,C.M.; HAMERSKI,H.W.; KRAM,R.; The independent effects of gravity and inertia on running mechanics. J. Exp. Biol., v. 203, p. 229-238, 2000

CHANG,Y.H.;KRAM,R.; Metabolic cost of generating horizontal forces during human running. J. Appl. Physiol., v. 86 p. 1657-1662, 1999.

CHEEK,D.B.; The control of cell mass and replication. DNA unit a personal 20-year study. Early Hum. Dev., v. 12 p. 211-239, 1985.

CHIAVERINI,V.; Tecnologia mecânica. vol. 1 . São Paulo, Mcgraw-Hill do Brasil, p. 67-88, 1977. 
CHUI,L.A.; CASTLEMAN,K.R.; Morphometric analysis of rat muscle fibers following space flight and hypogravity. Physiologist, v. 23, p. S76-78, 1980. Supplement.

CLOSE,R.; Properties of motor units in fast and slow skeletal muscle of the rat. J. Physiol., v. 193 , p. $45-55,1967$.

DARR,K.C.; SCHULTZ,E.; Hindlimb suspension suppresses muscle growth and satellite cell proliferation. J. Appl. Physiol., v. 67, p.1827-1834, 1989

D’AUNNO,D.S.; ROBINSON,R.R.; SMITH G.S.; THOMASON,D.S.; BOOTH, F.W.; Intermittent acceleration as a countermeasure to soleus muscle atrophy. J Appl. Physiol., v. 72, p. 428-433, 1992.

DE-DONCKER,L.; PICQUET,F.; FALEMPIN,M.; Effects of cutaneous receptor stimulation on muscular atrophy developed in hindlimb unloading condition. J. Appl. Physiol., v. 89, p. 2344-2351, 2000.

DESPLANCHES,D; MAYET,M.H.; ILYINA-KAKUEVA,E.I.; $\quad$ SEMPORE,B.; FLANDROIS,R.; Skeletal muscle adaptation in rats flown on Cosmos 1667. J.Appl. Physiol., v. 68, p. 48-52, 1990.

EDGERTON,V.R.; ALLEN, D.L; LINDERMAN, J.K.; ROY, R.R.; BIGBEE, A.J.; GRINDELAND, R.E.; MUKKU, VENKAT.; Apoptosis: a mechanism contributing to remodeling of skeletal muscle in response to hindlimb unweighting. Am. J. Physiol. v. 273, p. C 579-C587, 1997.

EDGERTON,V.R.; BARNARD,R.J.;PETER,J.B.; MAIER,A.;SIMPSON,D.R.; Properties of immobilized hind-limb muscles of the Galago senegalensis. Exp. Neurol., v. 46, p. 115-131, 1975.

EDGERTON,V.R.; ROY,R.R.; Physiology of a microgravity environment. Invited review: Gravitational biology of the neuromotor systems: a perspective to the next era. J. Appl. Physiol., v. 89, p.1224-1231, 2000 
FAULKNER,J.A.; NIEMEYER,J.H.; MAXWELL,L.C.; WHITE,T.P.; Contractile properties of transplanted extensor digitorum longus muscle of the cat. J. Appl. PhysioL., v. 238, p. C120-C126, 1980.

FERRARI,G.; $\quad$ CUSELLA-DE $\quad$ ANGELIS,G.; $\quad$ COLETTA,M.; $\quad$ PAOLUCCI $\quad$ E.; STORNAIUOLO,A; COSSU,G; MAVILIO,F.; Muscle regeneration by bone marrow-derived myogenic progenitors. Science, v. 279, p. 1528-1530, 1998.

FISHBACK,G.D.; ROBBINS,N.; Changes in contractile properties of disused soleus muscle. J. Appl. Physiol., v. 201, p. 305-320, 1969.

FITTS,R.H.; METZGER,J.M.; RILEY,D.A.; UNSWORTH,B.R.; Models of disuse: a comparison of hindlimb suspension and immobilization. J. Appl. Physiol., v. 60, p. 19461953, 1986.

FITTS,R.H.; RILEY,D.R.; WIDRICK,J.J.; Physiology of a microgravity environment invited review: microgravity and skeletal muscle. J Appl. Physiol., v. 89, p. 823-839, 2000.

FRATESCHI,M.E.B.J.M.; Efeitos da imobilização e remobilização em algumas propriedades mecânicas do osso. Dissertação de mestrado em Bioengenharia, interunidades. Faculdade de Medicina de Ribeirão Preto/ Escola de Engenharia de São Carlos/ Instituto de Química de São Carlos, Universidade de São Paulo, 2002.

GARDETTO,P.R.; SCHLUTER,J.M.;FITTS,R.H.; Contractile function of single muscle fiber after hindlimb suspension. J. Appl. Physiol., v. 66, p. 2739-2749, 1989.

GOULD III,J.; A. Biomecânica básica na terapia esportiva e ortopédica. In: Fisioterapia na ortopedia e na medicina do esporte. São Paulo: Manole, p. 65-63. 1993.

GRAFSTEIN,B.; FORMAN,D.S.; Intracellular transport in neurons. Physiol. Rev., v. 60, p. 1167, 1980.

GRINDELAND,R.E.; $\quad$ ROY,R.R.; $\quad$ EDGERTON,V.R.;GROSSMAN,E.J.; $\quad$ MUKKU,V.R.; JIANG,B.;PIEROTTI,D.J.; RUDOLPH,I.; Interactive effects of growth hormone and exercise on muscles mass in suspended rats. Am. J. Physiol., v. 267, p. R316-R322, 1994. 
GUTH,L.; Trophic influences of nerve on muscle. Physiol. Rev., v. 48. p. 645, 1980.

GUTH,L; SAMAHA, F.J.; Qualitative differences between actomyosin ATPase of slow and fast mammalian muscle. Exp. Neurol., v. 25, p. 138-152, 1969.

GUTMAN,E.; HNIK,P.; The effect of use and disuse on neuromuscular functions. Elsevier, New York, 1963.

HENRIKSEN,E.J.;TISCHLER,M.E.;WOODMAN,C.R.;MUNOZ,K.A;

STUMP,C.S.;KIRBY,C.R.; Elevated interstitial fluid volume in soleus muscles unweight by spaceflight or suspension. J. Appl. Physiol., v. 75, p. 1650-1653, 1993.

HERBERT,M.E.; ROY,R.R.; EDGERTON,V.R.; Influence of one week hindlimb suspension and intermittent high load exercise on rat muscles. Exp. Neurol., v. 102, p. 190-198, 1988.

HERBISON,G.J.; JAWEED,M.M.; DITUNNO,J.F.; Muscle fiber atrophy after cast immobilization in the rat. Arch. Phys. Med. Rehabil., v. 59, p. 301-305, 1978.

HISLOP,P.J.; Responses of immobilized muscle to isometric exercise. J. Am. Phys. Ther. Assoc., v. 44, p. 339, 1964.

HIKIDA,R.S.; VAN NOSTRAN,S.;MURRAY,J.D.; STARON,R.S.; GORDON,S.E.; KRAEMER,W.J.; Myonuclear loss in atrophied soleus muscle fibers. Anat. Rec., v. 247, p. 350-354, 1997.

HOLLOSZY,J.O.; BOOTH,F.W.; Biochemical adaptations to endurance exercise in muscle. Ann. Rev. Physiol., v. 38, p. 273-291, 1976.

ILYNA-KAKUEVA,E.I.; PORTUGALOV,V.V.;KRIVENKOVA,N.P.; Space flight effects on the skeletal muscles of rats. Aviat. Space Environ. Med., v. 47, p. 700-703, 1976.

JÄRVINEN,M.; Healing of a crush injury in rat striated muscle. Acta Chir. Scand., v. 142, p. 47-56,1976 
JÄRVINEN,M.; EINOLA,S.A.; VIRTANEN,E.O.; Effect of the position of immobilization upon the tensile properties of the rat gastrocnemius muscle. Arch. Phisys. Med. Rehabil., v.73, p. 253-257, 1992.

JASPERS,S.R.; TISCHLER,M.E.; Atrophy and growth failure of rat hindlimb muscles in tail cast suspension. J. Appl. Physiol., v. 57, p. 1472-1479, 1984.

JIANG,B; ROY,R.R.; NAVARRO,C.;EDGERTON,V.R.; Atrophic response of rat soleus fibers subjected to a 4-day spaceflight. J. Appl. Physiol., v. 74, p. 527-531, 1993.

JIANG,B.; OHIRA,Y.; ROY,R.R.; NGUYEN,Q.; ILYINA-KAKUEVA,E.I.; OGANOV,V.; EDGERTON,V.R.; Adaptation of fibers in fast-twitch muscles of rats to spaceflight and hindlimb suspension. J. Appl. Physiol., v. 73, p. 58S-65S, 1992.

JOHNSON,M.A.; POLGAR,J.; WEIGHTMAN,D.; APPLETON,D.; Data on the distribution of fibre types in thirty-six human muscles. An autopsy study. J. Neurol. Sci., v. 18, p. 111$129,1973$.

KASPER,C.E.; WHITE,T.P.; MAXWELL,L.C.; Running during recovery from hindlimb suspension induces muscular injury. J. Appl. Physiol., v. 68, p. 533-539, 1990.

KASPER,C.E.; MCNULTY,A.L.; OTTO,A.J.; THOMAS,D.P.; Alterations in skeletal muscle. Related to impaired physical mobility: An empirical model. Res. Nurs. Health, v. 16, p. 265-273, 1993.

KASPER,C.E.; XUN,L.; Cytoplasm-to-myonucleus ratios in plantaris and soleus muscle fibers following hindlimb suspension. J. Muscle Res. Cell Motil., v. 17, p. 603-610, 1996.

KAVOUNOUDIAS,A.; ROLL,R.; ROLL, J.P.; The plantar sole is a "dynamometric map" for human balance control. Neuroreport, v. 9, p. 3247-3252, 1998.

KLITGAARD,H.A.; A model for quantitative strenght training of hindlimb muscles of the rat. J. Appl. Physiol., v. 64, p. 1740-1745, 1988. 
KOSLOVSKAIA,I.B.; BARMIN,V.A.; STEPANTSOV,V.I.; KHARITONOV,N.M.; Results of studies of motor functions in long-term space fights. Physiologist, v. 33, p. S1-S3, 1990.

KOSLOVSKAIA,I.B.; KREIDICH， Y.V.; OGANOV， V.S.;KOSERENKO， O.P.; Pathophysiology of motor functions in prolonged space flights. Acta Astronaut., v. 8, p. 1059-1072, 1981.

MACMASTER,P.E.; Tendon and muscle ruptures. J. Bone Joint Surg., v. 15, p. 705-722, 1933.

McALL,G.E.; $\quad$ ALLEN,D.L.; $\quad$ LINDERMAN,J.K.; $\quad$ GRINDELAND,R.E.; $\quad$ ROY,R.R.; MUKKU,V.R.; EDGERTON,V.R.; Maintenance of myonuclear domain size in rat soleus after overload and growth hormone/IGF-I treatment. J. Appl. Physiol., v. 84, p.1407-1412, 1998.

MAIER,A.; CROCKETT,J.L.; SIMPSON,D.R.; SAUBERT IV,C.W.; EDGERTON,V.R.; Properties of immobilized guinea pig hindlimb muscles. Am. J. Physiol., v. 231, p. 15201526, 1976.

MARTIN,T.P.;EDGERTON,V.R.; GRINDELAND,R.E.; Influence of spaceflight on rat skeletal muscle. J. Appl. Physiol., v. 65, p. 2318-2325, 1988.

MAURO,A.; Satellite cell of skeletal muscle fibers. J. Biophys. Biochem. Cytol., v. 9, p. 493-498, 1961.

MAX,S.R.; Disuse atrophy of skeletal muscle loss of functional activity of mitochondria. Biochem. Bioph. Res. Comm., v. 46, p.1394-1398, 1972.

MOREY,E.R.; Space flight and bone turnover, correlaction with a new rat model of weighlessness. Bioscience, v. 29, p. 168-172, 1979.

MOREY-HOLTON,E.; WRONSKI,J.; Animal models for simulating weightlessness. Physiologist, v. 24, p. S45- S48, 1981. 
MOSS,F.P.; LEBLOND C.P.; Satellite cells as the source of nuclei in muscles of growing rats. Anat. Rec., v. 170, p. 421-436, 1971

MOZDZIAK,P.E.; PULVERMACHER,P.M.; SCHULTZ,E.; Unloading of juvenile muscle results in a reduce muscle size 9 wk after reloading. J. Appl. Physiol., v. 88, p.158-167, 2000.

MOZDZIAK,P.E.; PULVERMACHER,P.M.; SCHULTZ,E.; Muscle regeration during hindlimb unloading results in a reduction in muscle size after reloading. J. Appl.Physiol., v. 91, p. 183-190, 2001.

MOZDZIAK,P.E.; SCHULTZ,E.; CASSENS,R.G.; Myonuclear accretion is a major determinant of avian skeletal muscle growth. Am. Physiol. Cell Physiol., v. 272, p. C565C571, 1997.

MOZDZIAK,P.E.; TRUONG,Q.; MACIUS,A.; SCHULTS,E.; Hindlimb suspension reduces muscles regeneration. Eur. J. Appl. Physiol., v. 78, p. 136-140, 1998.

MUSACCHIA,X.J.; DEAVERS,D.R.; MEININGER,G.A.; DAVIS,T.P.A model for hypokinesia: effects on muscle atrophy in the rat. J. Appl. Physiol., v. 48, p. 479-486, 1980.

MUSACCHIA,X.J.; STEFFAN,J.M.; DEAVERS,D.R.; Suspension restraint: Induced hipokinesia and antiorthostasis as a simulation of weightlessness. Physiologist., v. 24, p. S21-S22, 1981.

NEWLANDS,S.; $\quad$ LEVITT,L.K.; ROBINSON,C.S.; KARPF,A.B.; $\quad$ HODGSON,V.R.; WADE,R.P.; HARDEMAN,E.C.; Transcription occurs in pulses fibers. Genes Dev., v.12, p. 2748-2758, 1998.

NORMAN,T.L.; BRADLEY-POPOVICH,G.; CLOVIS,N.; CUTLIP,R.G.; BRYNER, R.W.; Aerobic exercise as a countermeasure for microgravity-induced bonne loss and muscle atrophy in a rat hindlimb suspension model. Aviat. Space Environ. Med., v. 71, p. 593-598, 2000. 
OGANOV,V.S.; $\quad$ SKURATOVA,S.A.; $\quad$ POTAPOV,A.N.; SHIRVINSKAYA,M.A.; Physiological mechanismes of adaptation of rat skeletal muscles to weightlessness an similar functional requiraments. Physiologist, v. 23, p. 516-521, 1980.

OHIRA,Y.; JIANG,B.; ROY,R.R.; OGANOV,V.; ILYNA-KAKUEVA,E.; MARINI,J.F.; EDGERTON,V.R.; Rat soleus muscle fiber responses to 14 days of spaceflight and hindlimb suspension. J. Appl. Physiol., v. 73, p. 51S-57S, 1992.

RALSTON,E.; HALL,Z.V.; Restricted distribuition of mRNA produced from a single nucleus in hybrid myotubes. J. Cell Biol., v. 119, p. 1063-1068, 1992.

RILEY,D.A.; $\quad$ ELLIS,S.; $\quad$ SLOCUM,G.R.; $\quad$ SATYANARAYANA,T.;BAIN,J.L.W.; SEDLAK,F.R.; Hipogravity-induced atrophy of rat soleus and extensor digitorum longus muscles. Muscle Nerve, v. 10, p. 560-568, 1987.

ROSE,S.J.; ROTHSTEIN,J.M.; Muscle biology and physical therapy. Phys. Ther., v. 62, p. 1754-1756, 1982

SCHULTZ,E.; DARR,K.C.; MACIUS,A.; Acute effects of hindlimb unweighting on satellite cells of growing skeletal muscle. J. Appl. Physiol., v. 76, p. 266-270, 1994.

SILVA, A.V.; Modelo de suspensão pela cauda e seu efeito em algumas propriedades mecânicas do osso do rato. Dissertação de mestrado em Bioengenharia., InterunidadesFaculdade de Medicina de Ribeirão Preto/ Escola de Engenharia de São Carlos/ Instituto de Química de São Carlos, Universidade de São Paulo, Ribeirão Preto, 2003.

SOUZA,S.A.; Ensaios mecânicos de materiais metálicos. 3. ed. São Paulo: Edgard Blücher Ltda, 3-58 , 1977

STEVENS,L.; MOUNIER,Y.; HOLY,X.; Functional adaptation of different rat skeletal muscles to wheigthlessness. Am. J. Physiol., v. 264, p. R770-R776, 1993.

TALMADGE,R.J.; ROY,R.R.;EDGERTON,V.R.; Distribution of myosin heavy chain isoforms in non-weight-bearing rat soleus muscle fibers. J. Appl. Physiol., v. 81, p. 540-546, 1996. 
TEMPLETON,G.H.; $\quad$ PADALINO,M.; MANTON,J.; LeCONEY,T.; HAGLER,H.; GLASBERG,M.- The influence of rat suspension-hipokisesia on the gastrocnemius muscle. Aviat. Space Environ. Med., 55: 381-386, 1984a.

TEMPLETON,G.H.; $\quad$ PADALINO,M.; $\quad$ MANTON,J.;GLASBERG,M.; $\quad$ SILVER,P.; DeMARTINO,G.; LECONEY,T.;KLUG,G.;HAGLER,H.;SUTKO,J.L.; The influence of suspension-hyperkinesias on the rat soleus muscle. J. App. Physiol. v. 56, p. 278-86, 1984b.

THOMASON,D.B.; BIGGS,R.B.; BOOTH,F.W.; Protein metabolism and $\beta$-myosin heavychain mRNA in unweighted soleus muscle. Am. J. Physiol., v. 257 p. R300-R305, 1989.

THOMASON,D.B.; BOOTH,F.W.; Atrophy of the soleus muscle by hindlimb unweighting. J. Appl. Physiol., v. 68, p. 1-20, 1990.

WEST,J.B.; Physiology of a microgravity environment. Historical perspectives: Physiology in microgravity. J. Appl. Physiol., v. 89, p. 379-384, 2000.

WIDRICK,J.J.; BANGARD,J.J.; KARHANEK,M.; FITTS,R.H.; Soleus fiber force and maximal shortening velocity after non-weight bearing with intermittent activity. J. Appl. Physiol., v. 80, p. 981-987,1996.

WIDRICK,J.J; FITTS,R.H.; Peak force and maximal shortening velocity after non-weightbearing and resistance exercise. J. Appl. Physiol., v. 82, p. 189-195, 1997.

WIDRICK,J.J.; KNUTH,S.T.; NORENBERG,K.M.; ROMATOWSKI,J.G.; BAIN,J.L.W.; RILEY,D.A.; KARHANEK,M.; TRAPPE,S.W.; TRAPPE,T.A.; $\quad$ COSTILL,D.L.; FITTS,R.H.; Effect of a 17 day spaceflight on contractile properties of human soleus fibers. J. Physiol., v. 516, p. 915-930, 1999.

WIDRICK,J.J.; ROMATOWSKI,J.G.; NORENBERG,K.M.; KNUTH,S.T.; BAIN,J.L.W.; RILEY,D.A.; TRAPPE,T.A.; COSTILLD.L.; TRAPPE,S.W.;FITTS,R.H.; Functional properties of slow and fast gastrocnemius muscle fibers after a 17- day spaceflight. J. Appl. Physiol., vol. 9, p. 2203-2211, 2001. 
WITZMANN,F.A.; KIM,D.H.; FITTS,R.H.; Recovery time course in contractile function of fast and slow skeletal muscle after hindlimb immobilization. J. Appl. Physiol., v. 52, p. 677$682,1982$.

WONG,T.S.; BOOTH,F.W.; Skeletal muscle enlargement with weight lifting exercise in rats. J. Appl. Physiol., 950-954, 1988.

YABLONKA-REUVENI,Z.; SEGER,R.; RIVERA,A.J.; Fibroblast growth factor promotes recruitment of skeletal muscle satellite cells in young and old rats. J. Histochem. Cytochem., v. 47, p. 23-42, 1999. 


\section{ANEXOS}

Anexo 1- Peso dos animais do Grupo Controle

\begin{tabular}{|c|c|}
\hline \multicolumn{2}{|c|}{ GRUPO CONTROLE } \\
\hline Peso do rato (g ) & Inicial \\
\hline Rato 1 & 280 \\
\hline Rato 2 & 285 \\
\hline Rato 3 & 280 \\
\hline Rato 4 & 260 \\
\hline Rato 5 & 250 \\
\hline Rato 6 & 250 \\
\hline Rato 7 & 240 \\
\hline Rato 8 & 260 \\
\hline Rato 9 & 275 \\
\hline Rato 10 & 275 \\
\hline Rato 11 & 260 \\
\hline Rato 12 & 250 \\
\hline média & 263,75 \\
\hline desv. padrão & 14,79
\end{tabular}


Anexo 2- Peso dos animais do Grupo 7 dias de suspensão

\begin{tabular}{|c|c|c|}
\hline \multicolumn{3}{|c|}{ GRUPO 7 DIAS DE SUSPENSÃO } \\
\hline & \multicolumn{2}{|c|}{ Peso do rato (g) } \\
\hline & Inicial & Ensaio \\
\hline Rato 1 & 260 & 250 \\
\hline Rato 2 & 255 & 250 \\
\hline Rato 3 & 255 & 250 \\
\hline Rato 4 & 250 & 235 \\
\hline Rato 5 & 270 & 265 \\
\hline Rato 6 & 240 & 230 \\
\hline Rato 7 & 215 & 210 \\
\hline Rato 8 & 230 & 230 \\
\hline Rato 9 & 235 & 230 \\
\hline Rato 10 & 265 & 235 \\
\hline Rato 11 & 235 & 195 \\
\hline média & 246,36 & 234,54 \\
\hline desv. padrão & 16,75 & 19,68
\end{tabular}


Anexo 3- Peso dos animais do Grupo 14 dias de suspensão

\begin{tabular}{|c|c|c|}
\hline \multicolumn{3}{|c|}{ GRUPO 14 DIAS DE SUSPENSÃO } \\
\hline & \multicolumn{2}{|c|}{ Peso do Rato (g) } \\
\hline & Inicial & Ensaio \\
\hline Rato 1 & 285 & 285 \\
\hline Rato 2 & 250 & 245 \\
\hline Rato 3 & 250 & 240 \\
\hline Rato 4 & 230 & 225 \\
\hline Rato 5 & 245 & 225 \\
\hline Rato 6 & 245 & 240 \\
\hline Rato 7 & 240 & 230 \\
\hline Rato 8 & 255 & 250 \\
\hline Rato 9 & 235 & 235 \\
\hline Rato 10 & 255 & 235 \\
\hline Rato 11 & 245 & 230 \\
\hline Rato 12 & 240 & 225 \\
\hline Rato 13 & 255 & 250 \\
\hline Rato 14 & 240 & 230 \\
\hline média & 247,86 & 238,93 \\
\hline desv. padrão & 13,11 & 15,83 \\
\hline
\end{tabular}


Anexo 4- Peso dos animais do Grupo 21 dias de suspensão

\begin{tabular}{|c|c|c|}
\hline \multicolumn{2}{|c|}{ GRUPO 21 DIAS DE SUSPENSÃO } \\
\hline & \multicolumn{2}{|c|}{ Peso do Rato (g) } \\
\hline & Inicial & Ensaio \\
\hline Rato 1 & 240 & 240 \\
\hline Rato 2 & 245 & 240 \\
\hline Rato 3 & 295 & 295 \\
\hline Rato 4 & 265 & 260 \\
\hline Rato 5 & 295 & 300 \\
\hline Rato 6 & 290 & 290 \\
\hline Rato 7 & 275 & 295 \\
\hline Rato 8 & 255 & 250 \\
\hline Rato 9 & 230 & 215 \\
\hline Rato 10 & 240 & 220 \\
\hline Rato 11 & 255 & 240 \\
\hline Rato 12 & 260 & 260 \\
\hline média & 262,08 & 29,75 \\
\hline desv. padrão & 22,41 & \\
\hline & & 29,75 \\
\hline
\end{tabular}


Anexo 5- Peso dos animais do Grupo 7 dias de suspensão seguido de 30 dias de natação

\begin{tabular}{|c|c|c|c|}
\hline & \multicolumn{3}{|c|}{ GRUPO 7 DIAS DE SUSPENSAO COM 30 DIAS DE NATAÇAO } \\
\hline & \multicolumn{3}{|c|}{ Peso do Rato (g) } \\
\hline & Inicial & Natação & Ensaio \\
\hline Rato 1 & 230 & 230 & 250 \\
\hline Rato 2 & 240 & 250 & 270 \\
\hline Rato 3 & 235 & 235 & 310 \\
\hline Rato 4 & 235 & 240 & 240 \\
\hline Rato 5 & 240 & 225 & 255 \\
\hline Rato 6 & 240 & 220 & 250 \\
\hline Rato 7 & 230 & 220 & 250 \\
\hline Rato 8 & 235 & 240 & 265 \\
\hline Rato 9 & 240 & 225 & 255 \\
\hline Rato 10 & 245 & 225 & 285 \\
\hline Rato 11 & 210 & 205 & 230 \\
\hline Rato 12 & 230 & 210 & 230 \\
\hline Rato 13 & 235 & 220 & 235 \\
\hline média & 234,23 & 226,54 & 255,83 \\
\hline desv. padrão & 8,62 & 12,48 & 23,72 \\
\hline
\end{tabular}


Anexo 6- Peso dos animais do Grupo 14 dias de suspensão seguido de 30 dias de natação

\begin{tabular}{|c|c|c|c|}
\hline & \multicolumn{3}{|c|}{ GRUPO 14 DIAS SUSPENSAO COM 30 DIAS DE NATAÇAO } \\
\hline & \multicolumn{3}{|c|}{ Peso do Rato (g) } \\
\hline & Inicial & Natação & Ensaio \\
\hline Rato 1 & 260 & 240 & 300 \\
\hline Rato 2 & 250 & 220 & 255 \\
\hline Rato 3 & 255 & 225 & 280 \\
\hline Rato 4 & 250 & 245 & 275 \\
\hline Rato 5 & 255 & 220 & 260 \\
\hline Rato 6 & 235 & 210 & 245 \\
\hline Rato 7 & 225 & 210 & 275 \\
\hline Rato 8 & 230 & 230 & 235 \\
\hline Rato 9 & 230 & 220 & 225 \\
\hline Rato 10 & 230 & 205 & 235 \\
\hline Rato 11 & 250 & 240 & 280 \\
\hline Rato 12 & 260 & 245 & 280 \\
\hline Rato 13 & 240 & 215 & 245 \\
\hline Rato 14 & 255 & 230 & 265 \\
\hline Rato 15 & 235 & 215 & 230 \\
\hline média & 244,00 & 224,67 & 259,00 \\
\hline desv. padrão. & 12,28 & 13,16 & 22,54 \\
\hline
\end{tabular}


Anexo 7- Peso dos animais do Grupo 21 dias de suspensão seguido de 30 dias de natação

\begin{tabular}{|c|c|c|c|}
\hline & \multicolumn{3}{|c|}{ GRUPO 21 DIAS DE SUSPENSÃO COM 30 DIAS DE NATAÇÃO } \\
\hline & \multicolumn{3}{|c|}{ Peso do Rato (g) } \\
\hline & Inicial & Natação & Ensaio \\
\hline Rato 1 & 280 & 310 & 340 \\
\hline Rato 2 & 250 & 260 & 265 \\
\hline Rato 3 & 270 & 255 & 270 \\
\hline Rato 4 & 280 & 270 & 275 \\
\hline Rato 5 & 250 & 245 & 260 \\
\hline Rato 6 & 245 & 225 & 260 \\
\hline Rato 7 & 240 & 240 & 240 \\
\hline Rato 8 & 265 & 250 & 265 \\
\hline Rato 9 & 245 & 255 & 275 \\
\hline Rato 10 & 270 & 255 & 270 \\
\hline Rato 11 & 250 & 240 & 235 \\
\hline Rato 12 & 270 & 240 & 255 \\
\hline Rato 13 & 240 & 225 & 255 \\
\hline Rato 14 & 230 & 215 & 235 \\
\hline média & 256,07 & 248,93 & 264,29 \\
\hline desv. padrão. & 16,07 & 23,14 & 25,63 \\
\hline
\end{tabular}


Anexo 8: Valores lidos durante os ensaios mecânicos realizados com os músculos gastrocnêmios dos animais controle

\begin{tabular}{|c|c|c|c|c|c|c|c|c|c|c|c|c|}
\hline DEF & R1 & R2 & R3 & R4 & R 5 & R6 & R7 & R 8 & R9 & R 10 & R 11 & R 12 \\
\hline$\overline{0}$ & 20 & 20 & 20 & 20 & 20 & 20 & 20 & 20 & 20 & 20 & 20 & 20 \\
\hline 0,5 & 38 & 29 & 33 & 55 & 31 & 31 & 26 & 35 & 45 & 28 & 37 & 44 \\
\hline 1 & 46 & 36 & 43 & 70 & 40 & 38 & 29 & 51 & 72 & 36 & 55 & 65 \\
\hline 1,5 & 58 & 43 & 57 & 85 & 48 & 48 & 38 & 68 & 97 & 40 & 73 & 87 \\
\hline 2 & 74 & 51 & 69 & 100 & 60 & 57 & 47 & 90 & 128 & 51 & 92 & 117 \\
\hline 2,5 & 102 & 62 & 78 & 117 & 67 & 73 & 57 & 110 & 157 & 60 & 114 & 146 \\
\hline 3 & 114 & 66 & 94 & 136 & 78 & 84 & 67 & 135 & 189 & 68 & 138 & 179 \\
\hline 3,5 & 128 & 78 & 107 & 150 & 90 & 102 & 79 & 163 & 213 & 78 & 162 & 209 \\
\hline 4 & 148 & 91 & 122 & 166 & 102 & 119 & 87 & 186 & 238 & 90 & 188 & 242 \\
\hline 4,5 & 165 & 101 & 134 & 184 & 116 & 134 & 102 & 210 & 264 & 103 & 210 & 275 \\
\hline 5 & 185 & 111 & 151 & 199 & 131 & 155 & 116 & 233 & 289 & 115 & 240 & 300 \\
\hline 5,5 & 207 & 123 & 168 & 220 & 143 & 173 & 130 & 252 & 313 & 126 & 266 & 331 \\
\hline 6 & 228 & 133 & 184 & 239 & 161 & 197 & 144 & 271 & 338 & 142 & 295 & 352 \\
\hline 6,5 & 253 & 145 & 200 & 261 & 177 & 217 & 157 & 287 & 361 & 153 & 323 & 378 \\
\hline 7 & 272 & 156 & 214 & 280 & 195 & 238 & 175 & 300 & 382 & 168 & 349 & 390 \\
\hline 7,5 & 292 & 172 & 233 & 297 & 216 & 262 & 190 & 311 & 400 & 179 & 369 & 403 \\
\hline 8 & 310 & 184 & 250 & 312 & 234 & 280 & 207 & 319 & 414 & 198 & 384 & 411 \\
\hline 8,5 & 328 & 196 & 262 & 332 & 249 & 303 & 225 & 328 & 423 & 210 & 397 & 408 \\
\hline 9 & 342 & 206 & 279 & 341 & 269 & 321 & 239 & 336 & 431 & 228 & 409 & 408 \\
\hline 9,5 & 352 & 221 & 292 & 355 & 278 & 339 & 252 & 340 & 435 & 245 & 410 & 401 \\
\hline 10 & 362 & 230 & 300 & 365 & 290 & 353 & 266 & 340 & 442 & 257 & 414 & 408 \\
\hline 10,5 & 369 & 244 & 316 & 370 & 302 & 369 & 280 & 337 & 445 & 270 & 410 & 406 \\
\hline 11 & 372 & 253 & 324 & 377 & 310 & 380 & 291 & 334 & 447 & 280 & 408 & 399 \\
\hline 11,5 & 375 & 260 & 330 & 381 & 320 & 392 & 304 & 333 & 448 & 290 & 405 & 383 \\
\hline 12 & 376 & 274 & 336 & 383 & 328 & 399 & 313 & 322 & 449 & 298 & 394 & 384 \\
\hline 12,5 & 371 & 285 & 341 & 383 & 334 & 402 & 322 & 312 & 445 & 303 & 387 & 375 \\
\hline 13 & 362 & 293 & 345 & 383 & 342 & 405 & 330 & 286 & 440 & 313 & 372 & 363 \\
\hline 13,5 & 344 & 304 & 347 & 381 & 348 & 401 & 335 & 273 & 433 & 314 & 359 & 350 \\
\hline 14 & 322 & 310 & 349 & 375 & 353 & 399 & 338 & 248 & 428 & 319 & 344 & 319 \\
\hline 14,5 & 304 & 319 & 348 & 370 & 350 & 395 & 335 & 215 & 418 & 323 & 330 & 278 \\
\hline 15 & 272 & 320 & 342 & 362 & 353 & 391 & 329 & 192 & 407 & 325 & 313 & 229 \\
\hline 15,5 & 223 & 326 & 336 & 352 & 347 & 380 & 325 & 167 & 391 & 325 & 295 & 199 \\
\hline 16 & 174 & 333 & 325 & 338 & 342 & 373 & 320 & 148 & 366 & 320 & 276 & 172 \\
\hline 16,5 & 130 & 336 & 319 & 321 & 334 & 365 & 315 & 126 & 290 & 310 & 251 & 138 \\
\hline 17 & 86 & 338 & 307 & 299 & 330 & 355 & 309 & 112 & 240 & 301 & 208 & 104 \\
\hline 17,5 & 67 & 342 & 290 & 273 & 317 & 340 & 301 & 99 & 183 & 284 & 177 & 86 \\
\hline 18 & 51 & 340 & 270 & 242 & 306 & 320 & 294 & 88 & 137 & 266 & 151 & 68 \\
\hline \multirow[t]{11}{*}{18,5} & 39 & 340 & 244 & 216 & 280 & 282 & 281 & 76 & 99 & 246 & 130 & \\
\hline & & 336 & 204 & 189 & 254 & 240 & 262 & & 81 & 222 & 109 & \\
\hline & & 324 & 177 & 164 & 233 & 198 & 240 & & 71 & 191 & 94 & \\
\hline & & 283 & 143 & 144 & 209 & 170 & 217 & & & 159 & 80 & \\
\hline & & 259 & 118 & 130 & 179 & 155 & 195 & & & 137 & & \\
\hline & & 228 & 98 & 115 & 153 & 139 & 168 & & & 116 & & \\
\hline & & 187 & 75 & 94 & 130 & 126 & 149 & & & 97 & & \\
\hline & & 158 & 52 & 80 & 94 & 113 & 133 & & & 79 & & \\
\hline & & 110 & 40 & 67 & 84 & 104 & 121 & & & & & \\
\hline & & 78 & 31 & & 66 & 93 & 106 & & & & & \\
\hline & & 59 & & & & 85 & 94 & & & & & \\
\hline
\end{tabular}


Anexo 9: Valores lidos durante os ensaios mecânicos realizados com os músculos gastrocnêmios dos animais suspensos durante 7 dias.

\begin{tabular}{|c|c|c|c|c|c|c|c|c|c|c|c|}
\hline DEF & R 1 & R 2 & R 3 & R 4 & R 5 & R 6 & R 7 & R 8 & R 9 & R 10 & R 11 \\
\hline 0 & 20 & 20 & 20 & 20 & 20 & 20 & 20 & 20 & 20 & 20 & 20 \\
\hline 0,5 & 43 & 27 & 24 & 24 & 23 & 25 & 40 & 25 & 29 & 23 & 30 \\
\hline 1 & 63 & 34 & 28 & 33 & 23 & 31 & 55 & 35 & 30 & 24 & 38 \\
\hline 1,5 & 80 & 41 & 33 & 41 & 26 & 35 & 70 & 44 & 33 & 28 & 45 \\
\hline 2 & 103 & 51 & 40 & 50 & 27 & 44 & 84 & 53 & 38 & 31 & 52 \\
\hline 2,5 & 126 & 63 & 46 & 60 & 31 & 51 & 100 & 60 & 42 & 38 & 60 \\
\hline 3 & 148 & 76 & 53 & 68 & 33 & 60 & 114 & 66 & 50 & 43 & 67 \\
\hline 3,5 & 173 & 88 & 60 & 84 & 39 & 70 & 127 & 76 & 53 & 47 & 75 \\
\hline 4 & 200 & 103 & 70 & 93 & 41 & 80 & 145 & 79 & 64 & 52 & 86 \\
\hline 4,5 & 220 & 115 & 78 & 108 & 51 & 92 & 160 & 90 & 73 & 59 & 96 \\
\hline 5 & 240 & 137 & 89 & 120 & 55 & 106 & 180 & 101 & 87 & 70 & 108 \\
\hline 5,5 & 261 & 151 & 99 & 140 & 63 & 118 & 190 & 114 & 94 & 77 & 115 \\
\hline 6 & 278 & 168 & 108 & 156 & 74 & 133 & 202 & 127 & 110 & 87 & 126 \\
\hline 6,5 & 291 & 186 & 115 & 178 & 87 & 149 & 202 & 139 & 131 & 98 & 140 \\
\hline 7 & 303 & 201 & 128 & 197 & 96 & 167 & 209 & 151 & 146 & 110 & 150 \\
\hline 7,5 & 312 & 219 & 140 & 220 & 110 & 182 & 225 & 165 & 166 & 124 & 164 \\
\hline 8 & 317 & 235 & 155 & 240 & 125 & 200 & 240 & 176 & 186 & 138 & 174 \\
\hline 8,5 & 324 & 248 & 170 & 262 & 141 & 219 & 248 & 187 & 206 & 153 & 185 \\
\hline 9 & 327 & 262 & 184 & 282 & 156 & 239 & 260 & 198 & 227 & 169 & 194 \\
\hline 9,5 & 328 & 275 & 201 & 300 & 178 & 259 & 266 & 207 & 247 & 182 & 201 \\
\hline 10 & 324 & 282 & 214 & 314 & 195 & 275 & 270 & 218 & 265 & 198 & 207 \\
\hline 10,5 & 322 & 287 & 229 & 322 & 210 & 294 & 273 & 230 & 281 & 218 & 210 \\
\hline 11 & 316 & 293 & 244 & 330 & 228 & 312 & 273 & 237 & 298 & 229 & 213 \\
\hline 11,5 & 314 & 297 & 255 & 336 & 247 & 329 & 274 & 242 & 313 & 239 & 207 \\
\hline 12 & 307 & 300 & 266 & 346 & 266 & 343 & 269 & 225 & 323 & 246 & 179 \\
\hline 12,5 & 297 & 303 & 276 & 351 & 281 & 357 & 267 & 237 & 332 & 252 & 149 \\
\hline 13 & 289 & 303 & 284 & 355 & 297 & 366 & 261 & 242 & 338 & 256 & 133 \\
\hline 13,5 & 277 & 306 & 288 & 357 & 308 & 374 & 254 & 225 & 344 & 258 & 120 \\
\hline 14 & 262 & 306 & 293 & 362 & 319 & 383 & 246 & 237 & 349 & 256 & 112 \\
\hline 14,5 & 248 & 308 & 298 & 363 & 330 & & 236 & 252 & 352 & 251 & 102 \\
\hline 15 & 224 & 308 & 301 & 347 & 335 & & 223 & 262 & 353 & 248 & 95 \\
\hline 15,5 & 204 & 305 & 304 & 364 & 344 & & 209 & 270 & 351 & 242 & 90 \\
\hline 16 & 186 & 305 & 304 & 370 & 349 & & 192 & 279 & 351 & 239 & 84 \\
\hline 16,5 & 165 & 304 & 303 & 371 & 355 & & 178 & 283 & 345 & 229 & 78 \\
\hline 17 & 151 & 300 & 301 & 372 & 356 & & 164 & 289 & 340 & 222 & \\
\hline 17,5 & 129 & 295 & 297 & 375 & 360 & & 152 & 293 & 332 & 214 & \\
\hline 18 & 114 & 289 & 290 & 379 & 358 & & 138 & 294 & 320 & 204 & \\
\hline 18,5 & 105 & 278 & 279 & 377 & 358 & & 130 & 295 & 296 & 191 & \\
\hline 19 & 93 & 265 & 267 & 380 & 355 & & 116 & 295 & 272 & 175 & \\
\hline 19,5 & 87 & 250 & 253 & 379 & 353 & & 105 & 294 & 252 & 158 & \\
\hline 20 & 75 & 235 & 235 & 375 & 349 & & 92 & 288 & 233 & 142 & \\
\hline 20,5 & 68 & 218 & 219 & 366 & 340 & & 79 & 281 & 208 & 122 & \\
\hline 21 & 62 & 195 & 200 & 350 & 326 & & 72 & 276 & 188 & 100 & \\
\hline \multirow[t]{9}{*}{21,5} & 55 & 175 & 179 & 328 & 315 & & & 266 & 164 & 90 & \\
\hline & & 152 & 155 & 302 & 301 & & & 255 & 142 & & \\
\hline & & 136 & 130 & 277 & 286 & & & 239 & 124 & & \\
\hline & & 122 & 109 & 255 & 270 & & & 222 & 105 & & \\
\hline & & 108 & 90 & 236 & 249 & & & 209 & 84 & & \\
\hline & & 95 & 74 & 215 & 224 & & & 193 & 70 & & \\
\hline & & 85 & 62 & 195 & 195 & & & 176 & & & \\
\hline & & 74 & 55 & 174 & 169 & & & 159 & & & \\
\hline & & 65 & 46 & 155 & 145 & & & 143 & & & \\
\hline
\end{tabular}


Anexo 10: Valores lidos durante os ensaios mecânicos realizados com os músculos gastrocnêmios dos animais suspensos durante 14 dias.

\begin{tabular}{|c|c|c|c|c|c|c|c|c|c|c|c|c|c|c|}
\hline$\overline{\mathrm{DEF}}$ & $\overline{\mathrm{R} 1}$ & R2 & R3 & R4 & R5 & R6 & R7 & R 8 & $\overline{\mathrm{R} 9}$ & R 10 & R 11 & R 12 & R13 & R 14 \\
\hline 0 & 20 & 20 & 20 & 20 & 20 & 20 & 20 & 20 & 20 & 20 & 20 & 20 & 20 & 20 \\
\hline 0,5 & 26 & 35 & 22 & 21 & 40 & 33 & 34 & 27 & 32 & 40 & 33 & 29 & 32 & 31 \\
\hline 1 & 36 & 41 & 32 & 27 & 56 & 42 & 42 & 32 & 38 & 56 & 41 & 38 & 42 & 42 \\
\hline 1,5 & 43 & 50 & 43 & 33 & 67 & 50 & 53 & 41 & 48 & 75 & 52 & 49 & 55 & 62 \\
\hline 2 & 51 & 61 & 53 & 38 & 78 & 57 & 60 & 46 & 55 & 95 & 67 & 59 & 65 & 75 \\
\hline 2,5 & 57 & 67 & 65 & 49 & 91 & 64 & 74 & 51 & 64 & 116 & 76 & 71 & 79 & 94 \\
\hline 3 & 67 & 77 & 77 & 55 & 105 & 74 & 84 & 56 & 75 & 136 & 89 & 83 & 97 & 117 \\
\hline 3,5 & 74 & 90 & 87 & 65 & 121 & 81 & 99 & 65 & 89 & 156 & 102 & 97 & 113 & 141 \\
\hline 4 & 88 & 98 & 100 & 73 & 136 & 91 & 109 & 72 & 103 & 177 & 116 & 108 & 130 & 165 \\
\hline 4,5 & 101 & 108 & 115 & 82 & 151 & 101 & 123 & 81 & 122 & 198 & 130 & 127 & 148 & 190 \\
\hline 5 & 115 & 118 & 127 & 92 & 168 & 115 & 140 & 89 & 139 & 215 & 145 & 145 & 169 & 217 \\
\hline 5,5 & 130 & 128 & 140 & 102 & 185 & 123 & 152 & 97 & 158 & 234 & 163 & 164 & 188 & 240 \\
\hline 6 & 147 & 138 & 154 & 111 & 200 & 138 & 166 & 108 & 178 & 250 & 180 & 179 & 207 & 260 \\
\hline 6,5 & 160 & 149 & 165 & 122 & 217 & 150 & 180 & 118 & 198 & 270 & 198 & 197 & 224 & 282 \\
\hline 7 & 177 & 161 & 183 & 136 & 230 & 152 & 194 & 128 & 218 & 285 & 219 & 217 & 245 & 300 \\
\hline 7,5 & 187 & 175 & 200 & 149 & 245 & 159 & 208 & 139 & 237 & 299 & 235 & 233 & 262 & 315 \\
\hline 8 & 191 & 185 & 212 & 160 & 254 & 188 & 218 & 149 & 251 & 318 & 232 & 251 & 279 & 327 \\
\hline 8,5 & 201 & 200 & 230 & 177 & 265 & 202 & 233 & 157 & 267 & 332 & 266 & 263 & 293 & 336 \\
\hline 9 & 220 & 213 & 243 & 186 & 273 & 214 & 242 & 169 & 280 & 343 & 278 & 275 & 308 & 331 \\
\hline 9,5 & 231 & 230 & 257 & 200 & 285 & 225 & 253 & 179 & 294 & 350 & 298 & 290 & 322 & 347 \\
\hline 10 & 246 & 244 & 276 & 212 & 290 & 236 & 266 & 186 & 305 & 360 & 306 & 306 & 337 & 350 \\
\hline 10,5 & 261 & 251 & 286 & 227 & 298 & 249 & 278 & 192 & 313 & 369 & 312 & 321 & 347 & 351 \\
\hline 11 & 277 & 271 & 297 & 235 & 301 & 256 & 287 & 206 & 320 & 373 & 317 & 334 & 358 & 349 \\
\hline 11,5 & 290 & 286 & 305 & 247 & 308 & 264 & 295 & 216 & 326 & 380 & 320 & 344 & 365 & 346 \\
\hline 12 & 306 & 299 & 312 & 268 & 310 & 269 & 302 & 228 & 332 & 386 & 324 & 340 & 371 & 342 \\
\hline 12,5 & 317 & 310 & 319 & 280 & 309 & 282 & 309 & 236 & 333 & 390 & 325 & 317 & 374 & 335 \\
\hline 13 & 330 & 321 & 325 & 292 & 305 & 291 & 315 & 248 & 332 & 393 & 322 & 295 & 376 & 329 \\
\hline 13,5 & 340 & 334 & 328 & 300 & 300 & 298 & 319 & 259 & 329 & 394 & 314 & 272 & 376 & 318 \\
\hline 14 & 349 & 339 & 330 & 308 & 299 & 304 & 323 & 264 & 320 & 392 & 304 & 248 & 376 & 302 \\
\hline 14,5 & 355 & 347 & 331 & 317 & 295 & 310 & 325 & 275 & 314 & 389 & 290 & 222 & 374 & 284 \\
\hline 15 & 358 & 353 & 331 & 320 & 292 & 313 & 326 & 283 & 306 & 381 & 273 & 199 & 369 & 260 \\
\hline 15,5 & 365 & 356 & 327 & 322 & 286 & 315 & 327 & 290 & 294 & 370 & 262 & 173 & 359 & 239 \\
\hline 16 & 370 & 355 & 318 & 325 & 275 & 320 & 323 & 299 & 277 & 358 & 251 & 139 & 345 & 217 \\
\hline 16,5 & 375 & 353 & 309 & 321 & 259 & 323 & 321 & 300 & 256 & 346 & 242 & 90 & 334 & 196 \\
\hline 17 & 370 & 350 & 294 & 314 & 213 & 326 & 315 & 310 & 234 & 330 & 233 & 77 & 324 & 178 \\
\hline 17,5 & 377 & 347 & 277 & 304 & 192 & 329 & 306 & 317 & 204 & 311 & 219 & 70 & 315 & 163 \\
\hline 18 & 377 & 337 & 253 & 292 & 169 & 330 & 294 & 323 & 174 & 285 & 204 & & 300 & 149 \\
\hline 18,5 & 369 & 317 & 232 & 274 & 150 & 331 & 277 & 320 & 150 & 259 & 185 & & 285 & 134 \\
\hline 19 & 357 & 304 & 217 & 257 & 129 & 331 & 256 & 320 & 130 & 219 & 162 & & 267 & 119 \\
\hline 19,5 & 330 & 286 & 199 & 230 & 93 & 333 & 228 & 330 & 109 & 187 & 140 & & 245 & 103 \\
\hline 20 & 299 & 261 & 182 & 205 & 78 & 331 & 206 & 335 & 96 & 159 & 122 & & 219 & 88 \\
\hline 20,5 & 265 & 235 & 170 & 183 & 64 & 327 & 183 & 338 & 84 & 137 & 106 & & 195 & \\
\hline 21 & 236 & 204 & 156 & 161 & 47 & 321 & 162 & 340 & & 115 & 84 & & 181 & \\
\hline 21,5 & 199 & 175 & 143 & 133 & & 303 & 139 & 338 & & 92 & 72 & & 165 & \\
\hline 22 & 166 & 144 & 122 & 110 & & 287 & 100 & 334 & & 76 & & & 145 & \\
\hline 22,5 & 147 & 122 & 110 & 98 & & 258 & 80 & 310 & & 60 & & & 119 & \\
\hline 23 & 133 & & 97 & & & 229 & 64 & 299 & & & & & 99 & \\
\hline 23,5 & 120 & & & & & 195 & & 284 & & & & & & \\
\hline
\end{tabular}


Anexo 11: Valores lidos durante os ensaios mecânicos realizados com os músculos gastrocnêmios dos animais suspensos durante 21 dias.

\begin{tabular}{|c|c|c|c|c|c|c|c|c|c|c|c|c|}
\hline DEF & $\mathrm{R} 1$ & R2 & R3 & R4 & R 5 & R 6 & R7 & R 8 & $\overline{R 9}$ & R 10 & R 11 & R 12 \\
\hline$\overline{0}$ & 20 & 20 & 20 & 20 & 20 & 20 & 20 & 20 & 20 & 20 & 20 & 20 \\
\hline 0,5 & 25 & 23 & 31 & 28 & 26 & 24 & 24 & 43 & 26 & 30 & 25 & 33 \\
\hline 1 & 31 & 25 & 44 & 36 & 31 & 28 & 27 & 78 & 32 & 32 & 30 & 42 \\
\hline 1,5 & 37 & 30 & 58 & 46 & 36 & 36 & 31 & 93 & 40 & 36 & 37 & 50 \\
\hline 2 & 43 & 31 & 78 & 57 & 43 & 41 & 36 & 109 & 44 & 40 & 46 & 58 \\
\hline 2,5 & 50 & 32 & 93 & 65 & 50 & 48 & 39 & 134 & 51 & 41 & 56 & 69 \\
\hline 3 & 60 & 38 & 110 & 76 & 60 & 56 & 51 & 159 & 59 & 45 & 64 & 80 \\
\hline 3,5 & 70 & 39 & 127 & 85 & 69 & 65 & 59 & 182 & 66 & 45 & 75 & 95 \\
\hline 4 & 82 & 45 & 148 & 100 & 86 & 74 & 64 & 210 & 76 & 49 & 87 & 109 \\
\hline 4,5 & 95 & 46 & 165 & 114 & 99 & 87 & 72 & 235 & 83 & 51 & 100 & 126 \\
\hline 5 & 107 & 56 & 179 & 131 & 111 & 98 & 79 & 264 & 95 & 58 & 115 & 144 \\
\hline 5,5 & 120 & 60 & 197 & 144 & 125 & 110 & 87 & 282 & 108 & 60 & 133 & 165 \\
\hline 6 & 136 & 65 & 222 & 163 & 142 & 122 & 96 & 293 & 118 & 66 & 148 & 187 \\
\hline 6,5 & 152 & 75 & 239 & 177 & 156 & 139 & 108 & 301 & 133 & 72 & 165 & 207 \\
\hline 7 & 169 & 80 & 259 & 194 & 170 & 154 & 118 & 257 & 147 & 81 & 187 & 230 \\
\hline 7,5 & 188 & 88 & 273 & 209 & 182 & 169 & 131 & 290 & 162 & 87 & 202 & 249 \\
\hline 8 & 207 & 102 & 287 & 224 & 197 & 188 & 140 & 276 & 176 & 99 & 230 & 270 \\
\hline 8,5 & 228 & 118 & 299 & 240 & 213 & 205 & 151 & 261 & 192 & 108 & 253 & 289 \\
\hline 9 & 245 & 137 & 310 & 251 & 228 & 221 & 160 & 242 & 205 & 122 & 274 & 308 \\
\hline 9,5 & 263 & 152 & 312 & 263 & 243 & 234 & 171 & 224 & 220 & 133 & 296 & 327 \\
\hline 10 & 276 & 168 & 318 & 276 & 260 & 249 & 183 & 210 & 230 & 149 & 310 & 345 \\
\hline 10,5 & 293 & 182 & 326 & 284 & 259 & 266 & 194 & 196 & 221 & 163 & 328 & 362 \\
\hline 11 & 306 & 194 & 331 & 290 & 269 & 278 & 203 & 184 & 236 & 184 & 337 & 375 \\
\hline 11,5 & 310 & 211 & 331 & 293 & 280 & 291 & 212 & 173 & 253 & 198 & 340 & 386 \\
\hline 12 & 319 & 222 & 331 & 295 & 288 & 306 & 219 & 160 & 263 & 220 & 333 & 392 \\
\hline 12,5 & 326 & 233 & 326 & 295 & 295 & 320 & 224 & 149 & 229 & 239 & 339 & 396 \\
\hline 13 & 334 & 245 & 319 & 292 & 306 & 335 & 235 & 131 & 250 & 259 & 353 & 400 \\
\hline 13,5 & 340 & 256 & 313 & 285 & 313 & 344 & 231 & 121 & 265 & 275 & 362 & 400 \\
\hline 14 & 343 & 267 & 305 & 278 & 320 & 359 & 221 & 102 & 270 & 292 & 364 & 397 \\
\hline 14,5 & 346 & 275 & 308 & 268 & 327 & 366 & 196 & 90 & 235 & 304 & 366 & 396 \\
\hline 15 & 350 & 283 & 280 & 259 & 335 & 370 & 198 & 77 & 254 & 316 & 363 & 394 \\
\hline 15,5 & 351 & 286 & 262 & 247 & 346 & 375 & 217 & 52 & 265 & 322 & 360 & 396 \\
\hline 16 & 348 & 292 & 242 & 233 & 354 & 378 & 229 & 40 & 268 & 328 & 355 & 391 \\
\hline 16,5 & 348 & 296 & 218 & 217 & 364 & 380 & 228 & 28 & 271 & 330 & 346 & 388 \\
\hline 17 & 347 & 293 & 193 & 199 & 357 & 382 & 217 & & 268 & 324 & 337 & 375 \\
\hline 17,5 & 347 & 295 & 158 & 184 & 352 & 381 & 231 & & 264 & 323 & 326 & 369 \\
\hline 18 & 342 & 295 & 132 & 170 & 344 & 378 & 253 & & 260 & 319 & 311 & 360 \\
\hline 18,5 & 336 & 292 & 111 & 155 & 325 & 376 & 239 & & 255 & 315 & 298 & 351 \\
\hline 19 & 323 & 282 & 92 & 142 & 301 & 369 & 255 & & 249 & 308 & 284 & 342 \\
\hline 19,5 & 309 & 275 & 76 & 129 & 280 & 363 & 266 & & 241 & 302 & 269 & 328 \\
\hline 20 & 293 & 264 & & 109 & 256 & 354 & 273 & & 231 & 294 & 254 & 314 \\
\hline 20,5 & 277 & 244 & & 95 & 228 & 340 & 286 & & 220 & 281 & 242 & 299 \\
\hline 21 & 252 & 226 & & 79 & 199 & 319 & 295 & & 206 & 273 & 229 & 277 \\
\hline 21,5 & 227 & 211 & & 65 & 161 & 290 & 302 & & 188 & 253 & 211 & 249 \\
\hline 22 & 211 & 196 & & 53 & 135 & 260 & 309 & & 172 & & 188 & 212 \\
\hline 22,5 & 188 & 164 & & 43 & 115 & 225 & 315 & & 157 & & 165 & 179 \\
\hline 23 & 166 & 145 & & 38 & 102 & 193 & 320 & & 138 & & 145 & 155 \\
\hline 23,5 & 150 & 126 & & 35 & 77 & 168 & 320 & & 120 & & 129 & 136 \\
\hline \multirow[t]{2}{*}{24} & 134 & 105 & & 30 & 56 & 136 & 320 & & 105 & & & 114 \\
\hline & & 87 & & 25 & 44 & 119 & 317 & & 91 & & & 103 \\
\hline
\end{tabular}


Anexo 12: Valores lidos durante os ensaios mecânicos realizados com os músculos gastrocnêmios dos animais suspensos durante 7 dias seguidos de 30 dias de natação.

\begin{tabular}{|c|c|c|c|c|c|c|c|c|c|c|c|c|c|}
\hline$\overline{D E F}$ & $\mathrm{R} 1$ & $\mathrm{R} 2$ & R3 & R4 & $\mathrm{R} 5$ & R6 & R 7 & $\mathrm{R} 8$ & R9 & R 10 & R 11 & R 12 & R 13 \\
\hline 0 & 20 & 20 & 20 & 20 & 20 & 20 & 20 & 20 & 20 & 20 & 20 & 20 & 20 \\
\hline 0,5 & 36 & 26 & 31 & 30 & 34 & 33 & 36 & 33 & 41 & 34 & 35 & 41 & 30 \\
\hline 1 & 52 & 32 & 41 & 41 & 49 & 42 & 47 & 44 & 62 & 47 & 49 & 55 & 43 \\
\hline 1,5 & 69 & 38 & 51 & 60 & 63 & 50 & 61 & 54 & 86 & 59 & 60 & 74 & 53 \\
\hline 2 & 89 & 48 & 66 & 77 & 79 & 60 & 78 & 66 & 113 & 74 & 75 & 97 & 67 \\
\hline 2,5 & 112 & 57 & 88 & 96 & 93 & 71 & 94 & 77 & 145 & 86 & 90 & 122 & 83 \\
\hline 3 & 139 & 70 & 94 & 121 & 109 & 84 & 113 & 93 & 178 & 101 & 106 & 147 & 98 \\
\hline 3,5 & 165 & 84 & 112 & 146 & 124 & 100 & 133 & 105 & 210 & 116 & 124 & 195 & 117 \\
\hline 4 & 189 & 103 & 127 & 173 & 139 & 114 & 155 & 121 & 245 & 130 & 152 & 223 & 135 \\
\hline 4,5 & 212 & 117 & 148 & 202 & 154 & 132 & 178 & 138 & 278 & 146 & 166 & 254 & 152 \\
\hline 5 & 236 & 136 & 167 & 227 & 172 & 150 & 199 & 154 & 305 & 163 & 185 & 270 & 173 \\
\hline 5,5 & 258 & 154 & 188 & 257 & 188 & 169 & 221 & 173 & 334 & 180 & 206 & 291 & 192 \\
\hline 6 & 279 & 176 & 213 & 280 & 207 & 191 & 245 & 192 & 354 & 198 & 229 & 312 & 209 \\
\hline 6,5 & 298 & 198 & 234 & 305 & 225 & 209 & 268 & 210 & 378 & 216 & 250 & 335 & 230 \\
\hline 7 & 315 & 220 & 255 & 329 & 243 & 230 & 291 & 232 & 398 & 237 & 280 & 356 & 257 \\
\hline 7,5 & 330 & 245 & 278 & 349 & 256 & 252 & 313 & 250 & 414 & 254 & 300 & 374 & 270 \\
\hline 8 & 343 & 265 & 300 & 369 & 272 & 272 & 333 & 273 & 428 & 273 & 324 & 387 & 286 \\
\hline 8,5 & 353 & 281 & 326 & 386 & 284 & 290 & 352 & 288 & 440 & 289 & 292 & 395 & 304 \\
\hline 9 & 361 & 300 & 340 & 399 & 294 & 309 & 371 & 306 & 451 & 306 & 307 & 401 & 324 \\
\hline 9,5 & 369 & 318 & 371 & 411 & 303 & 327 & 386 & 320 & 459 & 322 & 316 & 404 & 337 \\
\hline 10 & 375 & 335 & 392 & 417 & 308 & 342 & 399 & 335 & 462 & 334 & 323 & 404 & 344 \\
\hline 10,5 & 377 & 350 & 411 & 420 & 312 & 358 & 405 & 348 & 463 & 344 & 330 & 403 & 348 \\
\hline 11 & 378 & 365 & 426 & 424 & 313 & 370 & 412 & 358 & 463 & 350 & 164 & 400 & 351 \\
\hline 11,5 & 379 & 375 & 431 & 424 & 312 & 379 & 415 & 367 & 463 & 355 & 184 & 395 & 353 \\
\hline 12 & 381 & 386 & 448 & 426 & 311 & 389 & 414 & 374 & 462 & 354 & 192 & 391 & 355 \\
\hline 12,5 & 378 & 391 & 452 & 429 & 311 & 394 & 414 & 382 & 457 & 353 & 115 & 385 & 356 \\
\hline 13 & 376 & 398 & 446 & 430 & 308 & 401 & 412 & 388 & 454 & 350 & 111 & 376 & 356 \\
\hline 13,5 & 370 & 398 & 441 & 433 & 303 & 403 & 410 & 394 & 448 & 348 & 97 & 365 & 356 \\
\hline 14 & 360 & 400 & 430 & 432 & 297 & 406 & 406 & 398 & 440 & 342 & & 351 & 354 \\
\hline 14,5 & 348 & 400 & 415 & 435 & 285 & 408 & 403 & 401 & 431 & 337 & & 336 & 351 \\
\hline 15 & 333 & 398 & 398 & 440 & 271 & 410 & 392 & 402 & 420 & 331 & & 319 & 346 \\
\hline 15,5 & 320 & 395 & 384 & 440 & 253 & 410 & 384 & 402 & 408 & 325 & & 293 & 340 \\
\hline 16 & 300 & 392 & 370 & 437 & 234 & 410 & 371 & 403 & 390 & 316 & & 265 & 334 \\
\hline 16,5 & 279 & 385 & 358 & 434 & 216 & 409 & 355 & 402 & 377 & 305 & & 237 & 330 \\
\hline 17 & 251 & 374 & 342 & 426 & 195 & 407 & 335 & 400 & 356 & 290 & & 215 & 326 \\
\hline 17,5 & 218 & 363 & 326 & 415 & 177 & 404 & 309 & 396 & 332 & 271 & & 195 & 315 \\
\hline 18 & 178 & 344 & 309 & 393 & 156 & 402 & 284 & 389 & 300 & 249 & & 171 & 306 \\
\hline 18,5 & 146 & 326 & 298 & 340 & 136 & 397 & 264 & 381 & 251 & 232 & & 146 & 295 \\
\hline 19 & 123 & 307 & 287 & 304 & 123 & 392 & 245 & 372 & 201 & 204 & & 104 & 286 \\
\hline 19,5 & 107 & 285 & 262 & 269 & 109 & 383 & 227 & 361 & 171 & 181 & & 92 & 269 \\
\hline \multirow[t]{9}{*}{20} & 90 & 263 & 236 & 230 & 97 & 376 & 204 & 348 & 145 & 156 & & & 254 \\
\hline & & 238 & 197 & 184 & & 360 & 184 & 325 & 122 & 130 & & & 230 \\
\hline & & 212 & 132 & 153 & & 338 & 145 & 285 & 109 & 108 & & & 206 \\
\hline & & 178 & 102 & 130 & & 309 & 95 & 220 & 96 & 90 & & & 176 \\
\hline & & 127 & 87 & 91 & & 276 & & 154 & & & & & 144 \\
\hline & & 92 & & & & 239 & & 96 & & & & & 122 \\
\hline & & & & & & 211 & & & & & & & 99 \\
\hline & & & & & & 176 & & & & & & & \\
\hline & & & & & & 130 & & & & & & & \\
\hline
\end{tabular}


Anexo 13: Valores lidos durante os ensaios mecânicos realizados com os músculos gastrocnêmios dos animais suspensos durante 14 dias seguidos de 30 dias de natação.

\begin{tabular}{|c|c|c|c|c|c|c|c|c|c|c|c|c|c|c|c|}
\hline DEF & R 1 & R2 & R 3 & R4 & R 5 & R6 & R7 & $\mathrm{R} 8$ & R9 & R 10 & R 11 & R 12 & R 13 & R 14 & R 15 \\
\hline 0 & 20 & 20 & 20 & 20 & 20 & 20 & 20 & 20 & 20 & 20 & 20 & 20 & 20 & 20 & 20 \\
\hline 0,5 & 33 & 30 & 35 & 41 & 30 & 41 & 32 & 39 & 31 & 38 & 27 & 39 & 44 & 44 & 29 \\
\hline 1 & 46 & 49 & 47 & 53 & 36 & 54 & 42 & 48 & 41 & 54 & 38 & 50 & 60 & 59 & 40 \\
\hline 1,5 & 57 & 64 & 62 & 67 & 40 & 61 & 52 & 59 & 52 & 64 & 52 & 60 & 78 & 74 & 51 \\
\hline 2 & 71 & 78 & 76 & 85 & 45 & 74 & 64 & 71 & 64 & 86 & 69 & 69 & 98 & 90 & 65 \\
\hline 2,5 & 84 & 96 & 94 & 102 & 53 & 86 & 73 & 83 & 80 & 106 & 90 & 80 & 117 & 109 & 78 \\
\hline 3 & 100 & 113 & 118 & 121 & 61 & 100 & 84 & 100 & 97 & 128 & 107 & 91 & 137 & 129 & 92 \\
\hline 3,5 & 118 & 137 & 145 & 143 & 70 & 113 & 97 & 116 & 115 & 150 & 128 & 102 & 155 & 148 & 109 \\
\hline 4 & 137 & 162 & 169 & 167 & 83 & 128 & 111 & 133 & 137 & 179 & 155 & 115 & 176 & 168 & 126 \\
\hline 4,5 & 155 & 189 & 195 & 190 & 95 & 145 & 128 & 152 & 160 & 198 & 179 & 128 & 195 & 188 & 143 \\
\hline 5 & 173 & 215 & 220 & 212 & 108 & 162 & 145 & 171 & 181 & 219 & 209 & 142 & 213 & 207 & 159 \\
\hline 5,5 & 188 & 240 & 245 & 236 & 124 & 180 & 165 & 189 & 202 & 236 & 232 & 158 & 228 & 228 & 178 \\
\hline 6 & 210 & 263 & 266 & 260 & 141 & 197 & 184 & 208 & 224 & 253 & 251 & 174 & 248 & 250 & 198 \\
\hline 6,5 & 228 & 284 & 288 & 279 & 155 & 217 & 204 & 235 & 243 & 270 & 274 & 192 & 266 & 269 & 222 \\
\hline 7 & 250 & 304 & 308 & 297 & 173 & 236 & 224 & 251 & 264 & 286 & 294 & 212 & 281 & 286 & 242 \\
\hline 7,5 & 264 & 322 & 328 & 313 & 186 & 255 & 244 & 273 & 282 & 299 & 313 & 234 & 297 & 305 & 261 \\
\hline 8 & 281 & 339 & 346 & 327 & 206 & 275 & 263 & 287 & 299 & 310 & 332 & 252 & 312 & 319 & 279 \\
\hline 8,5 & 298 & 352 & 359 & 338 & 220 & 284 & 285 & 293 & 311 & 318 & 352 & 271 & 325 & 334 & 298 \\
\hline 9 & 311 & 360 & 371 & 350 & 237 & 306 & 304 & 305 & 322 & 322 & 366 & 290 & 343 & 347 & 313 \\
\hline 9,5 & 321 & 370 & 382 & 360 & 252 & 310 & 321 & 325 & 330 & 327 & 380 & 307 & 355 & 355 & 325 \\
\hline 10 & 330 & 377 & 389 & 366 & 269 & 315 & 337 & 337 & 337 & 328 & 393 & 322 & 366 & 365 & 333 \\
\hline 10,5 & 336 & 382 & 395 & 374 & 281 & 329 & 353 & 348 & 342 & 329 & 403 & 337 & 377 & 371 & 340 \\
\hline 11 & 342 & 385 & 401 & 378 & 295 & 343 & 367 & 356 & 346 & 329 & 412 & 350 & 384 & 375 & 344 \\
\hline 11,5 & 345 & 387 & 406 & 380 & 305 & 355 & 378 & 361 & 347 & 327 & 420 & 364 & 390 & 380 & 347 \\
\hline 12 & 347 & 390 & 408 & 386 & 314 & 213 & 387 & 362 & 349 & 323 & 426 & 375 & 391 & 382 & 349 \\
\hline 12,5 & 350 & 386 & 410 & 388 & 320 & 232 & 396 & 362 & 349 & 320 & 428 & 387 & 393 & 386 & 352 \\
\hline 13 & 349 & 386 & 412 & 392 & 327 & 260 & 401 & 364 & 349 & 313 & 431 & 396 & 392 & 386 & 354 \\
\hline 13,5 & 345 & 377 & 416 & 390 & 330 & 301 & 405 & 362 & 349 & 304 & 432 & 402 & 387 & 385 & 357 \\
\hline 14 & 343 & 373 & 419 & 382 & 329 & 320 & 408 & 360 & 350 & 296 & 431 & 407 & 384 & 383 & 359 \\
\hline 14,5 & 338 & 369 & 420 & 380 & 332 & 329 & 415 & 358 & 350 & 287 & 428 & 407 & 381 & 380 & 359 \\
\hline 15 & 332 & 364 & 418 & 375 & 331 & 348 & 415 & 351 & 352 & 277 & 425 & 408 & 377 & 374 & 359 \\
\hline 15,5 & 322 & 355 & 420 & 362 & 330 & 365 & 416 & 341 & 351 & 263 & 419 & 408 & 373 & 368 & 356 \\
\hline 16 & 310 & 348 & 419 & 344 & 330 & 371 & 414 & 333 & 349 & 250 & 417 & 407 & 371 & 358 & 354 \\
\hline 16,5 & 296 & 337 & 415 & 318 & 327 & 380 & 411 & 317 & 343 & 235 & 414 & 405 & 368 & 346 & 348 \\
\hline 17 & 276 & 330 & 410 & 290 & 320 & 382 & 411 & 299 & 336 & 217 & 410 & 403 & 364 & 329 & 342 \\
\hline 17,5 & 251 & 320 & 405 & 262 & 314 & 384 & 407 & 282 & 327 & 202 & 405 & 403 & 359 & 309 & 336 \\
\hline 18 & 213 & 305 & 399 & 233 & 308 & 384 & 403 & 264 & 311 & 188 & 393 & 401 & 348 & 288 & 329 \\
\hline 18,5 & 176 & 280 & 391 & 208 & 301 & 380 & 398 & 245 & 299 & 174 & 381 & 397 & 335 & 273 & 312 \\
\hline 19 & 144 & 256 & 387 & 188 & 293 & 376 & 389 & 225 & 280 & 162 & 359 & 391 & 325 & 255 & 295 \\
\hline 19,5 & 125 & 224 & 377 & 177 & 280 & 368 & 374 & 202 & 260 & 148 & 328 & 388 & 311 & 236 & 266 \\
\hline 20 & 107 & 195 & 366 & 165 & 262 & 368 & 356 & 184 & 233 & 137 & 274 & 376 & 292 & 218 & 244 \\
\hline \multirow[t]{9}{*}{20,5} & 87 & 168 & 350 & 151 & 239 & 362 & 332 & 167 & 199 & 123 & 228 & 366 & 272 & 196 & 205 \\
\hline & & 149 & 328 & 142 & 201 & 354 & 307 & 149 & 150 & 114 & 174 & 353 & 250 & 170 & 166 \\
\hline & & 121 & 301 & 135 & 171 & 341 & 278 & 128 & 118 & 99 & 141 & 339 & 221 & 148 & 128 \\
\hline & & 92 & 269 & 124 & 149 & 322 & 258 & 99 & 92 & & 108 & 322 & 188 & 118 & 99 \\
\hline & & & 235 & 115 & 123 & 299 & 226 & & & & 80 & 308 & 154 & 85 & 87 \\
\hline & & & 198 & 103 & 97 & 271 & 196 & & & & & 288 & 122 & & \\
\hline & & & 169 & 92 & & 246 & 170 & & & & & 262 & 95 & & \\
\hline & & & 105 & & & 217 & 146 & & & & & 241 & & & \\
\hline & & & 85 & & & 195 & 121 & & & & & 200 & & & \\
\hline
\end{tabular}


Anexo 14: Valores lidos durante os ensaios mecânicos realizados com os músculos gastrocnêmios dos animais suspensos durante 21 dias seguidos de 30 dias de natação.

\begin{tabular}{|c|c|c|c|c|c|c|c|c|c|c|c|c|c|c|}
\hline DEF & R 1 & R2 & R3 & $\mathrm{R} 4$ & R 5 & R6 & R7 & R 8 & R9 & R 10 & R 11 & R 12 & R 13 & R 14 \\
\hline$\overline{0}$ & 20 & 20 & 20 & 20 & 20 & 20 & 20 & 20 & 20 & 20 & 20 & 20 & 20 & 20 \\
\hline 0,5 & 39 & 22 & 28 & 30 & 27 & 45 & 38 & 36 & 36 & 40 & 30 & 34 & 35 & 31 \\
\hline 1 & 52 & 28 & 43 & 42 & 37 & 63 & 58 & 52 & 58 & 61 & 37 & 50 & 47 & 42 \\
\hline 1,5 & 68 & 34 & 61 & 58 & 47 & 83 & 79 & 67 & 69 & 86 & 46 & 70 & 58 & 54 \\
\hline 2 & 86 & 40 & 80 & 74 & 63 & 105 & 103 & 80 & 86 & 112 & 56 & 88 & 72 & 70 \\
\hline 2,5 & 106 & 49 & 104 & 89 & 78 & 128 & 128 & 98 & 98 & 140 & 68 & 108 & 88 & 86 \\
\hline 3 & 126 & 57 & 132 & 105 & 95 & 145 & 155 & 114 & 115 & 170 & 83 & 125 & 106 & 102 \\
\hline 3,5 & 142 & 68 & 158 & 122 & 114 & 172 & 178 & 130 & 136 & 198 & 95 & 140 & 124 & 119 \\
\hline 4 & 165 & 82 & 182 & 142 & 131 & 192 & 207 & 149 & 155 & 220 & 110 & 156 & 144 & 134 \\
\hline 4,5 & 190 & 95 & 212 & 162 & 154 & 215 & 235 & 170 & 180 & 245 & 124 & 175 & 159 & 154 \\
\hline 5 & 206 & 108 & 235 & 185 & 175 & 232 & 261 & 188 & 200 & 267 & 142 & 192 & 179 & 169 \\
\hline 5,5 & 230 & 124 & 260 & 205 & 205 & 253 & 280 & 207 & 224 & 284 & 162 & 212 & 199 & 185 \\
\hline 6 & 251 & 141 & 284 & 228 & 228 & 272 & 312 & 227 & 247 & 306 & 180 & 235 & 217 & 200 \\
\hline 6,5 & 270 & 158 & 306 & 250 & 258 & 289 & 336 & 246 & 270 & 324 & 196 & 258 & 238 & 213 \\
\hline 7 & 311 & 175 & 330 & 270 & 283 & 307 & 361 & 264 & 290 & 340 & 216 & 280 & 256 & 226 \\
\hline 7,5 & 344 & 195 & 351 & 290 & 304 & 318 & 383 & 281 & 312 & 355 & 236 & 299 & 273 & 240 \\
\hline 8 & 367 & 216 & 373 & 310 & 324 & 325 & 400 & 298 & 332 & 370 & 255 & 317 & 290 & 252 \\
\hline 8,5 & 388 & 237 & 395 & 331 & 342 & 334 & 410 & 310 & 352 & 380 & 272 & 332 & 302 & 265 \\
\hline 9 & 410 & 255 & 413 & 352 & 355 & 340 & 418 & 322 & 368 & 390 & 287 & 346 & 313 & 275 \\
\hline 9,5 & 428 & 277 & 436 & 368 & 370 & 346 & 420 & 334 & 381 & 397 & 301 & 358 & 320 & 288 \\
\hline 10 & 439 & 297 & 454 & 385 & 382 & 348 & 421 & 342 & 391 & 401 & 313 & 370 & 329 & 298 \\
\hline 10,5 & 451 & 317 & 465 & 397 & 390 & 350 & 421 & 347 & 403 & 405 & 325 & 379 & 337 & 305 \\
\hline 11 & 458 & 334 & 477 & 408 & 396 & 355 & 419 & 352 & 409 & 407 & 330 & 377 & 343 & 312 \\
\hline 11,5 & 464 & 351 & 485 & 418 & 399 & 355 & 415 & 355 & 412 & 408 & 336 & 224 & 350 & 320 \\
\hline 12 & 470 & 362 & 490 & 424 & 400 & 351 & 405 & 356 & 220 & 408 & 342 & 240 & 351 & 323 \\
\hline 12,5 & 478 & 374 & 493 & 429 & 399 & 348 & 399 & 357 & 233 & 406 & 348 & 255 & 360 & 331 \\
\hline 13 & 487 & 385 & 495 & 431 & 396 & 340 & 393 & 359 & 251 & 404 & 350 & 272 & 363 & 332 \\
\hline 13,5 & 493 & 391 & 495 & 432 & 392 & 333 & 386 & 360 & 271 & 402 & 355 & 192 & 365 & 335 \\
\hline 14 & 500 & 399 & 493 & 433 & 389 & 325 & 380 & 356 & 288 & 399 & 359 & 152 & 367 & 337 \\
\hline 14,5 & 510 & 399 & 488 & 434 & 385 & 314 & 370 & 352 & 297 & 397 & 360 & 158 & 367 & 336 \\
\hline 15 & 512 & 402 & 421 & 433 & 381 & 300 & 360 & 343 & 305 & 392 & 361 & 162 & 363 & 333 \\
\hline 15,5 & 512 & 408 & 357 & 432 & 378 & 284 & 342 & 334 & 200 & 386 & 363 & 160 & 358 & 331 \\
\hline 16 & 512 & 408 & & 428 & 368 & 257 & 323 & 324 & 172 & 375 & 363 & 161 & 351 & 326 \\
\hline 16,5 & 510 & 410 & & 420 & 360 & 229 & 290 & 312 & 167 & 364 & 362 & 156 & 343 & 296 \\
\hline 17 & 506 & 408 & & 415 & 349 & 201 & 257 & 296 & 162 & 347 & 356 & 147 & 337 & 286 \\
\hline 17,5 & 501 & 407 & & 409 & 334 & 175 & 231 & 276 & 149 & 331 & 349 & 135 & 329 & 273 \\
\hline 18 & 492 & 404 & & 399 & 309 & 160 & 196 & 263 & 139 & 314 & 339 & 121 & 321 & 259 \\
\hline 18,5 & 475 & 400 & & 388 & 270 & 144 & 171 & 245 & 128 & 295 & 331 & 114 & 309 & 246 \\
\hline 19 & 458 & 394 & & 378 & 244 & 132 & 143 & 229 & 119 & 270 & 316 & 104 & 298 & 226 \\
\hline 19,5 & 433 & 388 & & 350 & 217 & 112 & 122 & 207 & 100 & 236 & 303 & 93 & 281 & 196 \\
\hline 20 & 410 & 379 & & 326 & 185 & 102 & 95 & 177 & 89 & 195 & 290 & & 264 & 168 \\
\hline 20,5 & 385 & 365 & & 303 & 156 & 93 & & 153 & & 171 & 274 & & 242 & 134 \\
\hline 21 & 337 & 350 & & 278 & 130 & & & 125 & & 149 & 251 & & 218 & 105 \\
\hline 21,5 & 278 & 331 & & 249 & 112 & & & 97 & & 130 & 222 & & 196 & 81 \\
\hline 22 & 227 & 307 & & 225 & 93 & & & & & 115 & 183 & & 170 & \\
\hline 22,5 & 194 & 285 & & 202 & & & & & & 99 & 144 & & 140 & \\
\hline 23 & 156 & 261 & & 183 & & & & & & & 113 & & 115 & \\
\hline 23,5 & 129 & & & 157 & & & & & & & 89 & & 89 & \\
\hline 24 & 105 & & & 135 & & & & & & & & & & \\
\hline
\end{tabular}


Anexo 15: Propriedades mecânicas do Grupo Controle

\begin{tabular}{cccccc}
\hline & \multicolumn{2}{c}{ Limite Elástico } & \multicolumn{2}{c}{ Limite Máximo } & \\
Animais & Carga $(\mathrm{N})$ & Deformação $\left(\times 10^{-3} \mathrm{~m}\right)$ & Carga $(\mathrm{N})$ & Deformação $\left(\times 10^{-3} \mathrm{~m}\right)$ & Rigidez \\
\hline 1 & 32,28 & 8,50 & 36,85 & 12,00 & 3779 \\
2 & 28,17 & 12,70 & 33,52 & 17,50 & 2245 \\
3 & 28,95 & 9,41 & 34,20 & 14,00 & 3120 \\
4 & 32,87 & 8,62 & 37,53 & 12,50 & 3696 \\
5 & 29,93 & 11,50 & 34,59 & 14,00 & 2568 \\
6 & 33,26 & 9,54 & 39,69 & 13,00 & 4041 \\
7 & 29,73 & 11,50 & 33,12 & 14,00 & 2551 \\
8 & 25,82 & 5,75 & 33,32 & 10,00 & 4422 \\
9 & 37,56 & 7,05 & 44,00 & 12,00 & 4767 \\
10 & 28,17 & 11,37 & 31,85 & 15,50 & 2645 \\
11 & 34,82 & 7,18 & 40,57 & 10,00 & 5293 \\
12 & 37,17 & 6,53 & 40,28 & 8,00 & 2754 \\
& & & & & 3490 \\
Média & 31,56 & 9,14 & 36,63 & 12,70 & 993 \\
\hline
\end{tabular}


Anexo 16: Propriedades mecânicas do Grupo 7 dias de suspensão.

\begin{tabular}{cccccc}
\hline & \multicolumn{2}{c}{ Limite Elástico } & \multicolumn{2}{c}{ Limite Máximo } & \\
Animais & Carga (N) & Deformação $\left(\times 10^{-3} \mathrm{~m}\right)$ & Carga $(\mathrm{N})$ & Deformação $\left(\times 10^{-3} \mathrm{~m}\right)$ & Rigidez \\
\hline 1 & 26,61 & 5,75 & 32,18 & 9,50 & 4491 \\
2 & 24,65 & 8,49 & 30,21 & 14,50 & 3252 \\
3 & 24,26 & 11,11 & 29,82 & 16,00 & 2855 \\
4 & 29,15 & 9,41 & 37,28 & 19,00 & 4060 \\
5 & 29,35 & 13,07 & 35,32 & 17,50 & 3377 \\
6 & 33,26 & 11,76 & 37,53 & 14,00 & 3161 \\
7 & 19,96 & 6,01 & 26,85 & 11,50 & 2929 \\
8 & 22,70 & 10,71 & 28,91 & 19,00 & 2100 \\
9 & 27,00 & 10,32 & 34,59 & 15,00 & 3825 \\
10 & 23,09 & 11,24 & 25,28 & 13,50 & 2850 \\
11 & 19,17 & 9,01 & 20,87 & 11,00 & 2142 \\
& & & & & 3186 \\
Média & 25,38 & 9,71 & 30,80 & 14,59 & 740 \\
\hline Desv.Pad & 4,22 & 2,29 & 5,23 & 3,15 & \\
\hline
\end{tabular}


Anexo 17: Propriedades mecânicas do Grupo 14 dias de suspensão.

\begin{tabular}{cccccc}
\hline & \multicolumn{2}{c}{ Limite Elástico } & \multicolumn{2}{c}{ Limite Máximo } & \\
Animais & Carga (N) & Deformação $\left(\times 10^{-3} \mathrm{~m}\right)$ & Carga $(\mathrm{N})$ & Deformação $\left(\times 10^{-3} \mathrm{~m}\right)$ & Rigidez \\
\hline 1 & 32,17 & 12,81 & 36,69 & 18,00 & 2797 \\
2 & 32,61 & 13,46 & 34,89 & 15,50 & 2640 \\
3 & 29,13 & 10,84 & 32,44 & 15,00 & 2857 \\
4 & 29,57 & 13,46 & 31,85 & 16,00 & 2486 \\
5 & 24,35 & 7,58 & 30,38 & 12,00 & 3040 \\
6 & 24,78 & 10,71 & 32,63 & 19,50 & 2385 \\
7 & 27,83 & 10,71 & 32,05 & 15,50 & 2598 \\
8 & 26,96 & 14,64 & 33,32 & 21,00 & 1927 \\
9 & 24,35 & 7,71 & 32,63 & 12,50 & 3728 \\
10 & 27,39 & 6,66 & 38,61 & 13,50 & 3782 \\
11 & 29,57 & 9,67 & 31,85 & 12,50 & 3281 \\
12 & 33,04 & 10,98 & 33,71 & 11,50 & 3611 \\
13 & 27,83 & 7,97 & 36,85 & 14,00 & 3705 \\
14 & 29,13 & 7,32 & 34,40 & 10,50 & 4461 \\
Média & 28,48 & & & & 3093 \\
Desv. Pad. & 2,87 & 10,32 & 33,74 & 14,78 & 694 \\
\hline
\end{tabular}


Anexo 18: Propriedades mecânicas do Grupo 21 dias de suspensão.

\begin{tabular}{cccccc}
\hline & \multicolumn{2}{c}{ Limite Elástico } & \multicolumn{3}{c}{ Limite Máximo } \\
Animais & Carga $(\mathrm{N})$ & Deformação $\left(\mathrm{x} 10^{-3} \mathrm{~m}\right)$ & $\begin{array}{c}\text { Carga } \\
(\mathrm{N})\end{array}$ & Deformação $\left(\mathrm{x} 10^{-3} \mathrm{~m}\right)$ & Rigidez \\
\hline 1 & 29,74 & 10,71 & 34,40 & 15,50 & 3450 \\
2 & 21,91 & 12,02 & 29,01 & 16,50 & 2748 \\
3 & 27,00 & 7,58 & 32,44 & 11,00 & 3562 \\
4 & 24,26 & 8,75 & 28,94 & 12,00 & 3070 \\
5 & 24,65 & 9,67 & 35,71 & 16,50 & 2903 \\
6 & 33,26 & 13,20 & 37,47 & 17,00 & 2765 \\
7 & 20,74 & 11,37 & 31,39 & 23,50 & 2060 \\
8 & 27,39 & 5,35 & 29,53 & 6,50 & 4932 \\
9 & 22,70 & 9,80 & 26,49 & 14,00 & 2861 \\
10 & 28,96 & 13,98 & 32,37 & 16,50 & 3633 \\
11 & 29,35 & 9,67 & 35,90 & 14,50 & 4406 \\
12 & 36,00 & 10,58 & 39,24 & 13,50 & 3722 \\
& & & & & \\
Média & 27,16 & 10, & 32,74 & 14,75 & 3343 \\
Desv. Pad. & 4,61 & 2,36 & 3,88 & 4,08 & 785 \\
\hline
\end{tabular}


Anexo 19: Propriedades mecânicas do Grupo 7 dias de suspensão seguidos de 30 dias de natação.

\begin{tabular}{cccccc}
\hline & \multicolumn{3}{c}{$\begin{array}{c}\text { Limite Elástico } \\
\text { Deformação }\left(\times 10^{-3}\right.\end{array}$} & \multicolumn{3}{c}{ Limite Máximo } \\
Animais & Carga $(\mathrm{N})$ & $\begin{array}{c}\text { Deformação }\left(\mathrm{x} 10^{-3}\right. \\
\mathrm{m})\end{array}$ & Rigidez \\
\hline 1 & 28,26 & 6,01 & 37,34 & 12,00 & 4629 \\
2 & 28,26 & 8,62 & 39,20 & 14,00 & 4199 \\
3 & 41,30 & 10,71 & 44,30 & 12,50 & 4329 \\
4 & 33,04 & 7,18 & 43,12 & 15,50 & 5270 \\
5 & 26,96 & 8,10 & 30,67 & 11,00 & 3166 \\
6 & 31,30 & 9,28 & 40,18 & 16,00 & 3864 \\
7 & 33,91 & 8,36 & 40,67 & 11,50 & 4255 \\
8 & 30,00 & 9,01 & 39,49 & 16,00 & 3821 \\
9 & 29,13 & 4,84 & 45,37 & 11,50 & 6197 \\
10 & 30,87 & 9,28 & 34,79 & 11,50 & 3476 \\
11 & 25,22 & 6,54 & 32,34 & 10,50 & 4287 \\
12 & 36,96 & 7,45 & 39,59 & 10,00 & 4289 \\
13 & 32,61 & 9,28 & 34,89 & 13,50 & 3672 \\
& & & & & \\
Média & 31,37 & 8,05 & 38,61 & 12,73 & 4265 \\
Desv. Pad. & 4,33 & 1,60 & 4,47 & 2,08 & 786 \\
\hline
\end{tabular}


Anexo 20: Propriedades mecânicas do Grupo 14 dias de suspensão seguidos de 30 dias de natação.

\begin{tabular}{cccccc}
\hline & \multicolumn{3}{c}{ Limite Elástico } & \multicolumn{3}{c}{ Limite Máximo } \\
Animais & Carga (N) & Deformação $\left(\times 10^{-3} \mathrm{~m}\right)$ & Carga $(\mathrm{N})$ & Deformação $\left(\mathrm{x} 10^{-3} \mathrm{~m}\right)$ & Rigidez \\
1 & 30,13 & 8,62 & 34,30 & 12,50 & 3601 \\
2 & 30,13 & 7,05 & 38,22 & 12,00 & 4805 \\
3 & 30,13 & 7,05 & 41,16 & 15,50 & 4656 \\
4 & 28,96 & 6,92 & 38,24 & 13,00 & 4434 \\
5 & 27,39 & 10,32 & 32,54 & 14,50 & 3104 \\
6 & 27,00 & 7,97 & 34,79 & 11,50 & 3760 \\
7 & 32,48 & 9,67 & 40,77 & 15,50 & 3884 \\
8 & 28,17 & 7,97 & 35,67 & 13,00 & 3751 \\
9 & 28,17 & 7,71 & 34,50 & 15,00 & 4071 \\
10 & 26,61 & 6,53 & 32,24 & 11,00 & 4041 \\
11 & 35,22 & 8,75 & 42,34 & 13,50 & 3887 \\
12 & 30,52 & 9,67 & 39,98 & 15,50 & 3768 \\
13 & 27,39 & 6,92 & 38,51 & 12,50 & 3562 \\
14 & 30,13 & 7,58 & 37,83 & 13,00 & 3613 \\
15 & 29,74 & 8,62 & 35,18 & 15,00 & 3991 \\
& & & & & 3929 \\
Média & 29,48 & 8,09 & 37,08 & 13,53 & 439 \\
Desv. Pad. & 2,26 & 1,15 & 3,17 & 1,52 & \\
\hline
\end{tabular}


Anexo 21: Propriedades mecânicas do Grupo 21 dias de suspensão seguidos de 30 dias de natação.

\begin{tabular}{cccccc}
\hline \multicolumn{2}{c}{ Limite Elástico } & \multicolumn{3}{c}{ Limite Máximo } \\
Animais & Carga (N) & Deformação $\left(\times 10^{-3} \mathrm{~m}\right)$ & Carga $(\mathrm{N})$ & Deformação $\left(\mathrm{x} 10^{-3} \mathrm{~m}\right)$ & Rigidez \\
\hline 1 & 41,74 & 9,40 & 50,18 & 15,00 & 4497 \\
2 & 34,50 & 11,63 & 40,18 & 16,50 & 3854 \\
3 & 40,17 & 8,75 & 48,51 & 13,00 & 4424 \\
4 & 35,22 & 9,28 & 42,53 & 14,50 & 4085 \\
5 & 30,52 & 7,70 & 39,20 & 12,00 & 5078 \\
6 & 27,00 & 6,00 & 34,79 & 11,50 & 4173 \\
7 & 37,96 & 7,58 & 41,26 & 10,50 & 5007 \\
8 & 29,74 & 8,10 & 35,28 & 13,50 & 3574 \\
9 & 35,22 & 8,62 & 40,38 & 11,50 & 4279 \\
10 & 31,70 & 6,40 & 39,98 & 12,00 & 4157 \\
11 & 27,48 & 8,75 & 35,57 & 16,00 & 3625 \\
12 & 31,65 & 8,10 & 37,14 & 10,50 & 3778 \\
13 & 28,52 & 7,97 & 35,97 & 14,50 & 3638 \\
14 & 24,04 & 7,71 & 30,03 & 14,00 & 3019 \\
& & & & & \\
Média & 32,53 & 8,28 & 39,36 & 13,21 & 4085 \\
Desv. Pad. & 5,18 & 1,36 & 5,35 & 1,94 & 563 \\
\hline
\end{tabular}

